UNIVERSIDADE DE BRASÍLIA

FACULDADE DE DIREITO

Curso de Graduação em Direito

ANA CAROLINA ALMEIDA NAYA

\title{
A TEORIA DA SUPRALEGALIDADE DAS \\ NORMAS INTERNACIONAIS E SUA APLICAÇÃO NO BRASIL
}

Brasília

2011 
ANA CAROLINA ALMEIDA NAYA

\section{A TEORIA DA SUPRALEGALIDADE DAS NORMAS INTERNACIONAIS E SUA APLICAÇÃO NO BRASIL}

Monografia apresentada como requisito necessário à obtenção de grau de Bacharel em Direito pela Universidade de Brasília.

Orientadora: Professora Christine Oliveira Peter da Silva.

Brasília

2011 
NAYA, Ana Carolina Almeida.

A teoria da supralegalidade das normas internacionais e sua aplicação no Brasil. Ana Carolina Almeida Naya. - Brasília: a autora, 2011.

Monografia apresentada como requisito necessário à obtenção de grau de Bacharel em Direito pela Universidade de Brasília.

Orientadora: Christine Oliveira Peter da Silva 


\section{A TEORIA DA SUPRALEGALIDADE DAS NORMAS INTERNACIONAIS E SUA APLICAÇÃO NO BRASIL}

Monografia apresentada como requisito necessário à obtenção de grau de Bacharel em Direito pela Universidade de Brasília.

Orientadora: Professora Christine Oliveira Peter da Silva.

Brasília, 8 de julho de 2011.

Banca Examinadora

Professora Mestre Christine Oliveira Peter da Silva (Orientadora)

Professor Doutor George Rodrigo Bandeira Galindo

Professora Mestre Tahinah Albuquerque Martins 


\section{AGRADECIMENTOS}

A Deus, porque sem sua força e companhia eu não conseguiria absolutamente nada, nem ao menos sonhar.

Aos meus pais, que sempre me acompanham e me apóiam em minhas decisões, buscando sempre a melhor forma de concretizá-las, pois me ensinaram o que é ser responsável e plantaram em mim a vontade de ser um bom ser humano - com tudo o que isso implica -, e hoje buscam colher o fruto do trabalho que tiveram.

Aos meus amigos, pois em muitas horas eu desistiria do caminho se não os tivesse ao meu lado para me reanimar após ouvirem minhas confissões. Embora alguns estejam distantes, estão sempre presentes em pensamentos e orações.

Aos professores, que muitas vezes foram verdadeiros mestres, ao me ensinar o que é admiração a um profissional capaz e bem qualificado, e também ao me mostrar como a vida é simples e complexa simultaneamente, e entender isso faz parte de um processo de amadurecimento que inclui a constante e eterna busca por conhecimento.

À minha orientadora, Christine Oliveira Peter da Silva, por toda a sua atenção durante a realização do trabalho, por seu modo meigo e determinado de correção, por seu incentivo e entusiasmo em ensinar questões acadêmicas e também lições de vida.

Aos membros da banca avaliadora, George Rodrigo Bandeira Galindo e Tahinah Albuquerque Martins, dispostos a contribuir para o presente trabalho com suas experiências acadêmicas.

A todos vocês, que, de uma maneira ou de outra, são marcantes em minha vida, contribuindo para que eu me torne a pessoa que sou.

Muito obrigada! 
"A justiça sustenta numa das mãos a balança que pesa o direito, e na outra, a espada de que se serve para o defender. A espada sem a balança é a força brutal; a balança sem a espada é a impotência do direito.” (Rudolf von Ihering) 


\section{RESUMO}

A presente monografia de final de curso busca averiguar as razões e a legitimidade da adoção da teoria da supralegalidade das normas internacionais pelo Brasil por meio de uma decisão jurisprudencial. A importância dessa análise advém da necessidade de cumprimento dos acordos internacionais firmados pelo país, os quais não podem estar submetidos à vontade do legislador local após a ratificação e promulgação, tendo em vista que o direito internacional é o campo do direito de maior diplomacia e o seu descumprimento poderia levar a graves sanções, como a guerra. Não se pretende achar uma verdade absoluta, mas, por meio do método lógico-sistemático e também de uma abordagem comparativa, analisar as outras hipóteses de integração das normas internacionais ao sistema normativo interno, como é a equiparação das normas que tratam de direitos humanos às normas constitucionais. A conclusão do trabalho é a de que, antes de ratificar uma norma internacional, o país deve submeter o texto a um corpo técnico para analisar se não há inconstitucionalidades, mas, uma vez adotado o acordo, ele deve ser cumprido para que o direito internacional permaneça eficaz - e a teoria da supralegalidade abarca essa possibilidade, quando bem adotada.

Palavras-chaves: supralegalidade; normas internacionais; aplicação por decisão jurisprudencial; cumprimento de acordos; direito internacional eficaz. 


\begin{abstract}
This work, at the end of the law course, intends to search the reasons and the legitimacy of supra-legal theory adoption for international standards through a judicial decision in Brazil. The importance of this analysis comes from the need of doing anything that was promised in the international agreements signed by the country, which cannot be submitted to the local legislature's will after being ratified and published. International law is an area of greater diplomacy and its non compliance could lead to serious sanctions, such as war. It is not intended to find an undeniable truth. In the other hand, through logical and systematic method and also a comparative approach, we propose to examine other possibilities of international standards' integration to the domestic regulatory system, as the assimilation between constitutional rules and human rights rules. The conclusion basically is that, before ratifying an international rule, the country must submit the text to a technical team to consider and decide whether it is unconstitutional or not, if it can be approved by the system. After that, it must be fulfilled, so international law remain effective - and the supra-legal theory embraces this possibility, when properly adopted and applied.
\end{abstract}

Key words: supra-legal theory; international standards; adoption through judicial decision; agreement's compliance; effective international law. 


\section{SUMÁRIO}

INTRODUÇÃO......

CAPÍTULO 1 - O Direito Internacional: desde seu início até sua aplicação no século XXI ....5

1.1 A origem, o histórico e os conceitos do direito internacional ........................................5

$1.2 \mathrm{O}$ questionamento da força aplicativa do direito internacional .................................... 13

1.3 As normas de direito internacional e a adesão a elas ................................................. 18

CAPÍTULO 2 - Direito Constitucional Brasileiro 28

2.1 O histórico da relação entre o direito (constitucional) brasileiro e o direito internacional ......

2.2 A relação entre os poderes da República e suas legitimidades para adotar mudanças...46

2.3 A modificação realizada pela Emenda Constitucional número 45/20046Erro! Indicador não defini

2.4 A mudança de entendimento do Supremo Tribunal Federal e sua aplicação7Erro! Indicador não do

CAPÍTULO 3 - A teoria da supralegalidade. .880

3.1 O significado da teoria da supralegalidade e sua aplicação no estrangeiro 81

3.2 As teorias optativas à teoria da supralegalidade. 85

3.3 As consequências da aplicação da teoria da supralegalidade no BrasilErro! Indicador não definido

CONCLUSÃO. .993 


\section{INTRODUÇÃO}

Em um mundo que se pretende globalizado, cada vez mais as interações entre diversos países se tornam intensas e necessárias ao desenvolvimento mundial. Afinal, o próprio conceito de globalização se refere à comunicação e integração econômica, política, social, cultural e interpessoal entre povos diferentes. Essa ideia de diálogo entre povos distintos para que se chegasse a entendimentos comuns no tocante a interesses divergentes se intensifica na época das Grandes Navegações, quando as distâncias passaram a ser "diminuídas" em decorrência da tecnologia marítima que permitia o alcance dos objetivos mercantis em menor espaço de tempo.

Desde então, o mundo se integra cada vez mais, assim como surgem novas questões a serem debatidas para que se chegue a um consenso. Inúmeros exemplos de tratados poderiam ser citados aqui, mas a finalidade deste trabalho não seria essa. O que é de nosso interesse é analisar se esses acordos internacionais são, de fato, necessários. E, se são, qual o motivo dessa necessidade e o que ocasionaria o descumprimento de uma norma internacional? Afinal, os mais avessos ao direito internacional sempre o acusaram de ineficácia em decorrência da falta de um órgão sancionador que aplicasse medidas severas àqueles inadimplentes em relação ao que haviam se proposto.

Por outro lado, pode-se perceber que, apesar das críticas que recebe, o direito internacional é um ramo do Direito que cresce e que ganha mais importância, à medida que os países cumprem o que acordam e obtêm vantagens advindas dessa integração. A diplomacia, embora nem sempre se mostre impositiva, tem sido eficaz em evitar conflitos bélicos.

Muitos diriam que isso é uma utopia ao ver as imagens da Guerra do Iraque ou da ameaça em invadir países árabes com a alegação de que é necessário lhes ensinar a democracia. No entanto, muitos mais seriam os conflitos caso o direito internacional não interviesse - e isso não é percebido porque, por óbvio, os conflitos que acontecem chamam muito mais atenção do que aqueles que são evitados.

Uma das maiores dificuldades encontradas pelo direito internacional é a de sua aplicação. Se não há uma norma fundamental que abrigue os direitos e obrigações a que todos os países estão submetidos, as normas internacionais costumam necessitar da concordância dos governantes locais para que sejam cumpridas. Desse modo, as Constituições de todos os países deveriam reconhecer a cooperação internacional e abrir a possibilidade de dispor de 
eventuais interesses internos em detrimento daquilo que seria melhor para a humanidade como um todo.

Sabe-se, no entanto, desde as lições de Maquiavel e Weber, que não é comum que o detentor do poder abdique dele ou reconheça que há uma outra instância que lhe é superior - isto é, que detém mais poder do que ele. De igual maneira pode-se perceber esse comportamento também na esfera estatal - a título de soberania, nenhum Estado deseja reconhecer que algum Conselho ou Organização teria o poder de lhe ditar regras de como agir, ainda que no plano internacional.

A partir do momento em que o Estado toma para si o monopólio do uso da força, sob a alegação de que a autotutela traria o caos à sociedade, chega-se à ideia de contrato social, desenvolvida por Hobbes e por Rousseau. No entanto, não há nenhum ente ou sujeito de direito internacional que tome para si essa responsabilidade, o que faz com que os Estados vivam em uma espécie de autotutela, cada um considerando a si mesmo mais soberano do que o outro, quando o ideal seria uma esfera de cooperação entre eles, pois, mediante conciliações, poderia ser obtido um grau de satisfação maior, em que todos ganhassem vantagens, ao invés de apenas um.

É então que se começa a analisar quais são os mecanismos de inserção do direito internacional nas esferas locais, considerando que a Constituição de cada país deve ter o mínimo de abertura para prever estruturas pelas quais os acordos realizados no plano internacional possam ser cumpridos. Afinal, de nada adiantaria para a comunidade internacional acordos que não fossem concretizados quando necessário, sob a alegação de que determinada lei interna não o admite. Se assim o é, não deveria haver acordo, pois, a partir do momento da ratificação, a comunidade cria uma expectativa de cumprimento, que não pode ser frustrada pela má-fé de um dos acordantes.

São apresentadas, assim, as teorias de recepção dos acordos internacionais, isto é, a força que eles possuem quando inseridos no ordenamento nacional. A equiparação às normas constitucionais seria uma hipótese em que se elevaria o direito internacional a uma importância que nem sempre é desejada pelos governantes locais, pois isso traria uma ingerência externa em suas decisões. Outras Constituições chegam a prever a possibilidade de serem alteradas por meio de tratados internacionais, caso esses sejam posteriores.

Por outro lado, a equivalência de uma norma internacional a uma lei ordinária não seria interessante para os atores internacionais, pois, a qualquer momento o acordo poderia deixar de ser cumprido sob a alegação de ser ilegal diante de uma norma posterior que o houvesse revogado. Nesse sentido, há Constituições que são omissas e outras que 
estabelecem a obrigação de cumprimento do tratado, mas sem tratar de hierarquia entre as normas.

A teoria adotada pelo Brasil, cuja Constituição é omissa, está em um plano intermediário: é a teoria da supralegalidade das normas internacionais, o que, resumidamente, atesta que as normas internacionais estariam abaixo hierarquicamente da Constituição Federal, mas, ao mesmo tempo, teriam maior força do que as leis ordinárias. Como não poderia deixar de ser, por se tratar de um assunto de relevância internacional, analisaremos comparativamente como outros países vislumbram essa problemática também, a fim de saber o que podemos esperar dos tratados que o Brasil assine com esses países.

Pretende-se analisar também o modo pelo qual tal teoria foi adotada no território nacional. A princípio, essa deveria ser uma decisão do legislador constituinte senão o originário, pelo menos o derivado, por ser uma questão que influenciaria diretamente a força da Carta Magna. O Brasil, no entanto, adotou a teoria durante um julgamento do Supremo Tribunal Federal, em sede de controle de constitucionalidade difuso. Apesar de essa Corte possuir o status de guardiã da Constituição, há quem sustente que houve, no caso em apreço, um ativismo judicial. Por outro lado, a Corte não poderia deixar sem resposta um caso que lhe foi submetido. Deveria, então, o Congresso Nacional ratificar essa decisão para que ela se tornasse erga omnes?

A partir de discussões lógico-sistemáticas, ou empíricas, não se pretende apontar defeitos e ditar regras de como se deve agir daqui por diante, mas busca-se, sim, um norte pelo qual devemos nos guiar a fim de, em deliberações futuras, tomar a melhor decisão, sem medo de ofender a uma verdade absoluta, pois essa por si mesma já seria questionável, e com a consciência tranquila trazida pela garantia dos direitos fundamentais e do respeito aos princípios da boa-fé, seja no plano interno ou externo.

Assim, no primeiro capítulo do presente trabalho, busca-se analisar o direito internacional como um todo, desde as suas origens até os dias atuais, como foi o seu desenvolvimento como disciplina autônoma e quais são suas relações com os demais ramos do direito. A importância desse estudo se encontra na necessidade do entendimento do funcionamento desse sistema, com suas especificidades, pois, somente a partir de então, sabendo também de suas deficiências, é que se pode buscar o ponto de encontro com o direito nacional.

Desse tema tratará o segundo capítulo, a partir de uma perspectiva constitucional, a fim de situar o Brasil e suas constituições em um plano histórico e mundial, investigando como foi o desenrolar dos acontecimentos e como estamos atualmente - além de 
abarcar o que ainda deve ser alterado e os méritos que devem ser dados ao que já foi construído, como é o caso da teoria da supralegalidade.

Ela será o tema central do terceiro capítulo, o qual discorrerá acerca dessa teoria, bem como analisará as opções a ela propostas que são aceitas em outros ordenamentos. Esse capítulo visa ao esclarecimento das vantagens e dos ônus da adoção dessa teoria, para que nossa escolha ao menos não seja ingênua, achando que essa é a única hipótese possível.

Com isso, busca-se despertar o interesse do leitor, seja ele do meio acadêmico ou não, a fim de demonstrar que o tema é altamente relevante, pois decidirá questões pragmáticas, como foi o caso do Recurso Extraordinário em que ficou decidida a impossibilidade de regulamentação da prisão civil do depositário infiel por meio de legislação ordinária. Como se procura demonstrar nas páginas seguintes, apesar de parecer um tema dogmático, são diretas suas implicações no desdobramento de casos concretos. 


\section{CAPÍTULO 1 - O DIREITO INTERNACIONAL: DESDE SEU INÍCIO ATÉ SUA APLICAÇÃO NO SÉCULO XXI}

O primeiro capítulo tratará do direito internacional como um todo. Por óbvio, não se pretende, aqui, esgotar o tema, mas, sim, estabelecer premissas sem as quais não seria possível desenvolver o presente trabalho.

Para tanto, devemos primeiramente investigar as origens desse ramo do direito, tendo em vista que, diversas de suas características atuais decorrem de sua construção histórica. A doutrina, por sua vez, não é unânime em relação ao marco inicial do direito internacional - nem tampouco a algumas de suas características, como veremos mais adiante, dentre as quais podem ser citados os entes que são considerados sujeitos de direito - e, por isso, apresentaremos sucintamente as teorias mais aceitas, dentre as quais escolheremos a que melhor nos atende, com base nas reflexões e na crítica feita neste estudo.

As críticas notoriamente recebidas em relação ao direito internacional também serão respondidas, pois de nada adiantaria estudar as relações entre os sujeitos de direito internacional se a regulamentação dessas relações não fosse, de fato, efetiva. É também preciso conhecer de que forma essa regulamentação se apresenta, isto é, como são criadas e, em seguida, aplicadas as normas de direito internacional.

Pode-se imaginar que tudo isso seria muito similar ao direito interno, tendo em vista a aplicação de certos princípios, como o pacta sunt servanda. No entanto, apesar de certas coincidências entre essas duas esferas, o direito internacional possui suas particularidades, como, por exemplo, as normas de ius cogens, que obrigam os Estados independente de sua adesão, como veremos.

\subsection{A ORIGEM, O HISTÓRICO E OS CONCEITOS DO DIREITO INTERNACIONAL}

A expressão "Direito Internacional" foi utilizada pela primeira vez no idioma inglês, no final do século XVIII, por Jeremias Bentham, a fim de distinguir as normas que 
visavam à regulamentação das relações entre Estados diferentes daquelas aplicadas no âmbito interno ${ }^{1}$.

Com a tradução para as línguas latinas, o sentido da locução foi modificado, uma vez que o termo "nação" designa um grupo de pessoas ligadas por aspectos culturais e históricos, dentre outros. O Direito Internacional não se prestava, em sua essência, à regulamentação entre nações, mas sim, à normatização das relações entre os Estados - ou seja, entre as instituições organizadas politicamente que administram o convívio entre os indivíduos de uma nação. ${ }^{2}$

No entanto, após realizadas essas considerações, não há mal nenhum em utilizar essa denominação, tendo em vista que ela já se encontra consagrada pela melhor doutrina. Alguns outros termos podem ser utilizados como seus sinônimos, como é o caso de "direito das gentes" e também de "direito transnacional", cada um trazendo consigo uma carga de significados. ${ }^{3}$

Enquanto o primeiro exemplo, também conhecido como jus inter gentes, se remete aos indivíduos como sujeitos de direito, além dos Estados em si, aplicando, assim, um aspecto mais atual e moderno à diplomacia, como veremos mais adiante, ele traz também a desvantagem de muitas vezes ser confundido com a terminologia utilizada para designar o direito aplicado em Roma. No tocante ao "direito transnacional”, seu benefício se refere à não-confusão entre público e privado, uma vez que o termo abrange essas duas classificações, muito questionadas cientificamente diante da interação de uma para com a outra. ${ }^{4}$

A origem e o desenvolvimento histórico do Direito Internacional estão intimamente ligados à sua conceituação. A depender da definição que adotarmos, estaremos escolhendo também um caminho doutrinário que enxerga esse campo do Direito de determinada maneira. Por isso, é interessante que analisemos algumas das correntes mais relevantes, antes de expor a que melhor atenderia ao nosso trabalho. Algumas delas foram sintetizadas por Celso de Mello, a seguir:

A definição de um ramo da ciência jurídica pode variar de acordo com o critério que se tome como ponto de partida. Pode-se levar em consideração os sujeitos da ordem jurídica internacional e então teríamos, por exemplo, a seguinte definição: "é o conjunto de regras que determinam os direitos e os deveres respectivos dos Estados nas suas relações mútuas"(Fauchille). Outro critério que se pode tomar por base é o modo de formação das normas jurídicas: "O D. Internacional se reduz às relações dos Estados e é o produto

\footnotetext{
${ }^{1}$ ACCIOLY (2000, p. 4)

${ }^{2}$ MELLO (2001, p. 43)

${ }^{3}$ MELLO (2001, p. 70)

${ }^{4}$ MELLO (2001, p. 68-69)
} 
da vontade destes mesmos Estados"(Bourquin). Alfred Verdross assinala que o melhor critério é o da "comunidade de que as normas emanam", uma vez que ele "tem por objeto ordenações jurídicas concretas". Levando em consideração tal afirmação, podemos definir o DIP como sendo: o conjunto de normas que regula as relações externas dos atores que compõem a sociedade internacional. Tais pessoas internacionais são as seguintes: Estados, organizações internacionais, o homem, etc. Uma boa definição é a fornecida por Jean Touscoz: "é o conjunto de regras e de instituições jurídicas que regem a sociedade internacional e que visam estabelecer a paz e a justiça e a promover o desenvolvimento". 5

Todas essas definições têm, em si, alguma falha. Aquelas que tentam conceituar o Direito Internacional apenas a partir da atuação dos Estados deixam de lado os outros sujeitos internacionais, que a cada dia mais passam a ter maior influência e visibilidade na cooperação internacional, como é o caso do homem, sujeito núcleo e destinatário dos direitos humanos, de relevância incontestável atualmente. ${ }^{6}$

Outras, por sua vez, ao tentarem abarcar a todos, acabam sendo por demais genéricas e não conseguem delimitar o objeto de estudo da disciplina, confundindo-o por diversas vezes com a política - a qual interage e influencia o Direito Internacional, mas não pode com ele ser confundida. ${ }^{7}$

Com isso, adotaremos neste trabalho a definição de Jean Touscoz, pois nos parece a conceituação mais completa possível, além de considerar também a formação de uma sociedade internacional, tema que desenvolveremos mais à frente. Por essa razão, pode ser que um dia essa definição passe a estar desatualizada, caso se forme uma comunidade internacional. No entanto, essa mudança não deve ocorrer a curto prazo e, então, ela nos servirá muito bem. ${ }^{8}$

Parte da doutrina, em que se encontra Sérgio A. Korff e Paul Vinogradoff e Celso D. de A. Mello, considera que o Direito Internacional estava presente desde a Antiguidade, levando em conta que os povos antigos já se relacionavam entre si e, para tanto, precisavam de normas que regulamentassem essas relações - inclusive com as sanções religiosas à disposição. Seria a aplicação do princípio "ubi societas ibi jus" ao Direito Internacional. $^{9}$

Aqueles que combatem essa doutrina alegam que o que havia na Grécia antiga era um Direito Intermunicipal, no máximo, entre as cidades-estados. Os estudiosos rebatem,

\footnotetext{
${ }^{5}$ MELLO (2001, p. 67)

${ }^{6}$ ACCIOLY (2000, p. 3)

${ }^{7}$ MELLO (2000, p. 78)

${ }^{8}$ TOUSCOZ apud MELLO (2001, p. 67)

${ }^{9}$ MELLO (2001, p. 152)
} 
afirmando que as cidades-estados, apesar de seu nome, eram dotadas de soberania e, assim, negociavam tratados de paz e de comércio mediante institutos que são utilizados até os dias de hoje, como a aprovação popular - hoje por meio da democracia indireta - antes de sua promulgação e ratificação. ${ }^{10}$

O Império Romano, diante de sua vastidão e sua filosofia de conquista dos povos, não foi modelo de negociação internacional. O "jus gentium" ali criado nada mais era do que um direito civil a que os estrangeiros estavam submetidos e que podiam invocar em caso de conflitos, tendo em vista que apenas os romanos podiam clamar o "jus civile", pois se imaginavam superiores aos povos que conquistavam. É então que se percebe, também, a falta de isonomia de tratamento aos povos, o que vai de encontro à diplomacia, apesar de possuir também alguns dos institutos atuais. ${ }^{11}$

Na Idade Média, a máxima autoridade estava presente na Igreja e, então, a maior sanção era a excomunhão. Ao mesmo tempo em que atuou pela Paz de Deus, proibindo guerra privadas e criando uma maior segurança ao proibir determinadas condutas, ainda que em tempos de guerra, a Igreja foi a responsável pelas Cruzadas, também chamada de "guerra santa”. Assim, Celso de Mello dispõe:

A maior contribuição da Igreja talvez tenha sido o conceito de guerra justa desenvolvido por Santo Ambrósio, Santo Agostinho e São Tomás de Aquino: a grande ponte de união entre estes autores é que todos eles analisaram a guerra justa intrinsecamente, isto é, a sua causa. Santo Agostinho ("De Officiis") ensinava que uma guerra seria justa quando se tratasse de defender o país contra os bárbaros e a casa contra os bandidos. Santo Agostinho ("De Civitate Dei" e "Contra Faustum") sustenta que a doutrina de Cristo não impede todas as guerras. Uma guerra necessária teria por fundamento a justiça. A guerra que preenche duas condições é legítima: a) se é justa; b) se há o direito de declarar a guerra. A guerra seria justa quando ela visasse a reparar uma injustiça. A guerra só pode ser declarada pelo chefe de Estado. Santo Tomás de Aquino ("Summa Theologica: Secunda Secundae - De Bello") é quem melhor estudou a noção de guerra justa, estabelecendo que para ela se configurar seriam necessárias três condições; a) que ela fosse declarada pelo príncipe, vez que ele é a autoridade pública competente; b) é necessário que ela tenha uma causa justa, enfim que a sua causa seja um direito violado; c) "que a intenção dos beligerantes seja reta", isto é, deve visar a "promover um bem ou evitar um mal". 12

Com a Reforma Protestante, a Igreja Católica perdeu seu poderio, embora deixasse princípios importantíssimos como a igualdade e a fraternidade cristãs para o Direito Internacional. É então, em 1648, quando a noção de Estado já está mais concretizada, que

\footnotetext{
${ }^{10} \operatorname{MELLO}(2001$, p. 153)

${ }^{11} \operatorname{ACCIOLY}(2000$, p. 154)

${ }^{12}$ MELLO (2001, p. 158)
} 
ocorre a Paz de Vestefália. Grande parte da doutrina, como Hedley Bull, Marcus Faro de Castro e Hildebrando Accioly, considera que esse é o marco inicial do Direito Internacional, sendo, de qualquer maneira, inegável a sua relevância. Nas palavras de Accioly:

Foi só, entretanto, no começo do século XVII que o direito internacional público apareceu, na verdade, como ciência autônoma, sistematizada. Esse novo período surgiu com Hugo de Groot ou Grotius ou Grócio ${ }^{13}$, nascido em Delft, na Holanda, e que viveu entre 1583 e 1645.(...) Sua obra-prima, a $D e$ jure belli ac pacis $^{14}$, inspirada, segundo se diz, na Guerra dos Trinta Anos, foi publicada em 1625 e suscitou enorme interesse nos principais círculos cultos europeus. Poucos anos depois, começava, com os tratados de Vestefália (1648), uma nova era na história política da Europa. Com a Paz de Vestefália, que pôs termo à Guerra dos Trinta Anos, triunfava o princípio da igualdade jurídica dos Estados, estabelecia-se em bases sólidas o princípio do equilíbrio europeu, surgiam os primeiros ensaios de uma regulamentação internacional positiva. Desde então, o desenvolvimento do direito internacional público marchou rapidamente. ${ }^{15}$

A importância da Paz de Vestefália se deve ao fato de ter sido neste congresso a primeira vez em que praticamente todos os países europeus se reuniram a fim de deliberar e alcançar a paz, encerrando as inúmeras guerras, inclusive religiosas, uns contra os outros como, por exemplo, a Guerra dos Trinta Anos. Decidiram, então, criar a Suíça, dar independência à Holanda e incorporar o território da Alsácia à França. Fracionava-se, então, o Sacro Império Romano Germânico, o que teria consequências futuras até se chegar à Primeira Guerra Mundial. $^{16}$

"O que surge com a Paz de Vestefália é uma sociedade internacional em que os Estados aceitam regras e instituições que limitam a sua ação, e que isto é do interesse comum". ${ }^{17}$ O princípio do equilíbrio europeu - entre Inglaterra, Áustria, Rússia, França e Prússia - foi de extrema relevância para o transcorrer da história, pois criava alianças que

${ }^{13}$ Grotius é considerado um dos precursores do direito internacional e o pai do naturalismo moderno ou jusracionalismo, pois, como teórico do Absolutismo que embasou a teoria do contrato social, afirmava que o homem deveria ser guiado por sua razão. Com isso, a partir do princípio da reta-razão, conseguiu congregar católicos e protestantes. Posteriormente, esse mesmo princípio foi a base para as normas de ius cogens, uma vez que elas seguem o raciocínio de que o direito positivo deve apenas refletir um direito já natural, trazido pela reta-razão. Além dessa, o direito internacional possui outras correntes teóricas, quais sejam: o positivismo de Kelsen, que valoriza a sanção aplicada pelos Estados; o sociologismo, que prioriza o fato social e seu contexto, o que favorece o indivíduo, uma vez que é ele quem gera a sociabilidade que gera o direito; o criticismo, de base liberal, que enxerga o direito com um caráter ideológico e é o fundamento para movimentos revolucionários, como o feminismo; e o negacionismo, do qual falaremos mais adiante, mas que trata o direito internacional como um conjunto de regras políticas ou morais apenas. (JACKSON e SORENSEN, 2007)

${ }^{14}$ Ao ser traduzido, o título da obra foi lido como "Da Paz e da Guerra", pois, como aponta Ricardo Zouch, a guerra deve ser a exceção, sendo, então, a paz a situação normal e que também precederia a guerra. (ZOUCH apud MELLO, 2001, p. 70)

${ }^{15}$ ACCIOLY (2000, p. 9)

${ }^{16}$ MELLO (2001, p. 159)

${ }^{17}$ BULL apud MELLO (2001, p. 159) 
perduraram até a Primeira Guerra Mundial e o Tratado de Versalhes, e enxergavam um interesse comum entre esses Estados: a manutenção da monarquia, embora não necessariamente a paz. ${ }^{18}$

A Revolução Francesa marcou o início da Idade Contemporânea, mas o que foi mais relevante para o Direito Internacional foi o Congresso de Viena, que ocorreu após a derrota de Napoleão. O Congresso, além de reunir quase todos os Estados europeus novamente, tomou decisões de suma importância, como o foi a adoção do princípio da intervenção e a criação da Santa Aliança entre Rússia, Prússia e Áustria, sendo posteriormente acrescida a Inglaterra e a própria França. ${ }^{19}$

A política intervencionista seguida pela Europa leva os Estados Unidos a criarem a Doutrina Monroe, que pregava "a América para os americanos", apoiando, assim, a independência das colônias. No final do século XIX surge o neocolonialismo, o qual influencia diretamente o Direito Internacional. Houve, ainda, a criação da Corte Permanente de Arbitragem de Haia, que é um marco para a matéria. ${ }^{20}$

Por sua vez, a Liga das Nações, formada após a Primeira Guerra Mundial e precursora das Nações Unidas foi fundamental para que as organizações internacionais passassem a ser consideradas como sujeitos do direito internacional. O Tratado de Latrão, de 1929, trouxe a problemática do Vaticano: a Santa Fé deveria ou não ser considerada um Estado? A questão perdeu importância quando se pacificou que, independente da classificação, ela seria um sujeito de direito, com capacidade postulatória, obrigações e direitos no plano internacional. ${ }^{21}$

Foi no início do século XX também que o Direito Internacional passou a ser tridimensional, isto é, passou a abranger as relações aéreas entre os Estados - sendo que antes tratava apenas da terra e do mar. Em 1945, após a Segunda Guerra Mundial, surgiu a Organização das Nações Unidas e, mais importante ainda, dois anos depois, foi criada a Comissão de Direito Internacional das Nações Unidas. ${ }^{22}$

A tecnologia avançada da Guerra Fria trouxe a necessidade de que o Direito Internacional passasse a tratar não apenas do plano tridimensional, mas também do espaço

\footnotetext{
${ }^{18}$ MELLO (2001, p. 160)

${ }^{19}$ MELLO (2001, p. 161)

${ }^{20}$ MELLO (2001, p. 161)

${ }^{21}$ MELLO (2001, p. 161)

${ }^{22}$ ACCIOLY (2000, p. 12)
} 
ultraterrestre e dos fundos marinhos. A consciência ambiental diante da degradação da natureza também fez com que esse campo fosse mais explorado em âmbito internacional. ${ }^{23}$

Assim, se considerarmos que o Direito Internacional é o ramo que trata das relações jurídicas entre Estados, apenas poderemos considerar que sua origem inicia após a formação dos Estados Nacionais, sob pena de ter sido criado um Direito sem objeto a ser regulamentado. Outros, ainda, consideram que o início do Internacionalismo se dá com a centralização das cidades-Estados italianas, no século XII, pois havia regras que regulamentavam a interrelação entre elas. ${ }^{24}$

Adotaremos a conceituação de Accioly, adepto da teoria segundo a qual o Direito Internacional surge com a Paz de Vestefália, quando os soberanos já formavam os Estados, no século XVII, qual seja: “o conjunto de normas jurídicas que regulam as relações mútuas dos Estados e, subsidiariamente, as das demais pessoas internacionais, como determinadas organizações, e dos indivíduos." 25

Caso considerássemos que a origem do Direito Internacional remonta à formação da sociedade humana, em razão dos conceitos mais atualizados que, diante da importância dos direitos humanos, passaram a enxergá-lo como principal sujeito da matéria aqui tratada, a diplomacia seria remetida à Antiguidade. No entanto, seguimos a ideia de Rezek, segundo o qual o indivíduo seria objeto do Direito Internacional, e não sujeito. ${ }^{26}$

Segundo Wilhelm Grewe, a história do Direito Internacional pode ser dividida em quatro épocas. A primeira era seria conhecida como Direito Internacional da Cristandade, pois teve como sua maior preocupação a convivência entre católicos e protestantes, sendo o seu marco, inclusive a Paz de Vestefália. Houve, também, a transplantação das estruturas sociais e da organização européia para a América - inclusive no campo religioso. ${ }^{27}$

Hugo Grocius, Alberto Gentili, Francisco de Vitória e Francisco Suárez foram os nomes dos grandes internacionalistas dessa época, que ficaram conhecidos como "pais do direito internacional" ou "fundadores do direito internacional", lembrando que todos eles consideravam como sujeitos de direito apenas os Estados - e só faziam parte da sociedade internacional os Estados europeus, que eram os cristãos. ${ }^{28}$

Essa ideologia leva à Segunda Era do Direito Internacional, qual seja, o Direito Internacional das Nações Civilizadas, que datou de meados do século XIX até a Primeira

\footnotetext{
${ }^{23}$ ACCIOLY (2000, p. 13)

${ }^{24}$ MELLO (2001, p. 155)

${ }^{25}$ ACCIOLY $(2000$, p.3)

${ }^{26}$ REZEK (2008a, p. 152)

${ }^{27}$ STEIGER (2001, p. 181)

${ }^{28}$ MELLO (2001, p. 163 et seq.)
} 
Guerra Mundial. Os Estados europeus desejam se expandir, mas ainda consideravam como civilizadas apenas as nações que seguissem seus modelos jurídico e religioso e, então, havia uma repartição desigual de direitos e deveres pelo mundo. ${ }^{29}$

Depois da Primeira Guerra Mundial, essa distinção formal acaba, e é então que se inicia o Direito Internacional Público da Humanidade que, apesar do título que recebeu, trouxe muita desigualdade. Embora as guerras sempre tenham sido uma preocupação desse ramo do Direito, houve, nesse período, a busca pela limitação, inclusive das guerras de conquista. Foi nesse instante que surgiram as Organizações Internacionais que visavam à paz. Reconhecem-se as minorias, preocupa-se com o indivíduo e busca-se judicializar os conflitos internacionais diante da iminência da guerra prevista durante a Guerra Fria. ${ }^{30}$

Essas preocupações trazem a última era do Direito Internacional, iniciada após a Segunda Guerra Mundial e que perdura até os dias de hoje. Conhecida como Direito Internacional Público do Cidadão Mundial, é caracterizada pelo fortalecimento da cooperação entre os Estados, mas também se volta a direitos transnacionais como os direitos humanos e ao meio-ambiente, tendo em vista as respostas comuns a essas temáticas que devem ser dadas por todos os Estados. ${ }^{31}$

Além disso, a soberania estatal passa a ser contestada diante da atuação dos novos atores e sujeitos de Direito Internacional. Isso não quer dizer, como veremos a seguir, que o Estado deixará de existir, pois, a exemplo da União Europeia, a cooperação entre os Estados não faz com que haja sua extinção, apenas que haja novos sujeitos de direito no âmbito internacional. ${ }^{32}$

Como un elemento de la imagen del mundo del tipo del "Estado constitucional" nos atrevemos a afirmar que los diversos Estados constitucionales no existen más "para sí", sino que de entrada constituyen una comunidad universal abierta. La referencia al mundo y a sus semejantes en dicho mundo (la humanidad) es um pedazo de su noción de si mismos, ya sea que se manifeste en forma de referencia a principios generales del derecho o a la internalización de derechos humanos universales (incluso en forma de una política exteior en favor de los derechos humanos), en forma de objetivos educacionales equivalentes, en la normación de valores fundamentales como la política por la paz mundial, la amistad y la cooperación internacionales, o en la obligación de proporcionar ayuda al desarollo y ayuda humanitaria ("ayuda mundial al hombre") ${ }^{33}$.

\footnotetext{
${ }^{29}$ STEIGER (2001, p. 184)

${ }^{30}$ STEIGER (2001, p. 187)

${ }^{31}$ STEIGER (2001, p. 190)

${ }^{32}$ MELLO (2001, p. 56)

${ }^{33}$ HÄBERLE (2003, p. 75)
} 


\section{$1.2 \mathrm{O}$ QUESTIONAMENTO DA FORÇA APLICATIVA DO DIREITO INTERNACIONAL}

No mundo contemporâneo, o intercâmbio de informações entre diferentes pontos do mundo, o movimento migratório das pessoas, a necessidade da produção estratégica de bens, serviços e tecnologias para otimização dos recursos disponíveis exigem que os países cooperem entre si, e daí surge a importância do Direito Internacional atualmente.

No entanto, as correntes teóricas do negacionismo e do criticismo veem a diplomacia como uma área da política, e não do direito, não enxergando a importância que tem a regulamentação das atitudes no plano internacional. Entre negadores práticos e negadores teóricos, as acusações são de que não há normas para os Estados, pois elas só seriam eficientes enquanto mantivessem a relação de forças naturais. ${ }^{34}$

A ausência de leis ou de sanções internacionais aplicáveis a todos os países é um dos argumentos utilizados por aqueles que buscam demonstrar que o Direito Internacional não seria Direito. Além de demonstrar uma visão extremamente positivista, esses autores parecem se esquecer que o Direito não se resume à lei. Além disso, podemos rebater essa crítica ao demonstrar que as normas costumeiras e também as de ius cogens independem de aceitação por parte dos Estados para serem aplicadas. ${ }^{35}$

No tocante à falta de previsão de sanção para os Estados ou, ainda, da aplicação das sanções previstas apenas para aqueles Estados com menor poderio, vale lembrar que "sanção não é um elemento inerente à norma jurídica. Ela é um simples elemento de execução. A sanção serve de camuflagem das estruturas de dominação". ${ }^{36}$, ou, ainda, a repressão seria exceção em qualquer sistema social ${ }^{37}$.

Ainda podemos mostrar que há, sim, no Direito Internacional sanções, como os embargos econômicos e boicotes, as represálias e, inclusive, a guerra. Não se pretende aqui defender a idéia de que os países teriam um "direito de guerra", pois assim estaríamos defasados em relação à perspectiva humanista implementada após o advento da Carta da

\footnotetext{
${ }^{34}$ MELLO (2001, p. 103)

${ }^{35}$ ACCIOLY (2000, p. 3)

${ }^{36}$ DEMICHEL apud MELLO (2001, p.74)

${ }^{37}$ MIAILLE apud MELLO (2001, p. 106)
} 
ONU, mas pretendemos demonstrar que a guerra seria a conseqüência última e mais grave, ainda que injusta, diante do descumprimento de uma norma internacional.

Além disso, "a sanção é um elemento externo ao direito e o que o caracteriza é a "possibilidade de sanção", 38 . A presença dos tribunais para adequar as normas gerais ao caso concreto também é prova de que, mesmo no direito interno, as normas devem ser adaptadas no momento de sua aplicação. Nos termos de Luhmann:

Por volta do fim do séc. XVIII também o modelo de ordem/obediência sofre uma revisão com vistas à relação entre legislação e jurisprudência. Isso se manifesta no fato de se desistir da reserva de interpretação (interpretationsvorbehalt) (refere législatif) do legislador, considerado até então necessário; a partir de agora não só a função da aplicação, mas também a da interpretação das leis é delegada aos Tribunais. Somente isso torna possível que se possa exigir que os Tribunais decidam todos os casos que lhes são apresentados. A "vinculação à lei" torna-se assim, por sua vez, objeto da interpretação por parte do Juiz. ${ }^{39}$

A ausência de tribunais ou a necessidade de aceitação daquela jurisdição pelo país - cláusula de jurisdição obrigatória presente nos tratados - também é apontada como uma prova de que não existe um Direito Internacional. Ora, o Direito, em sua essência, serve para regular as ações cotidianas, devendo ser os casos judicializados a exceção: "Quanto mais perfeita a ordem jurídica, menor a necessidade de coação" ${ }^{, 40}$.

De fato, os Estados pautam a sua conduta pelas normas de DIP, tanto assim é que as suas violações são poucas diante da intensidade da vida internacional. Das centenas de tratados existentes, alguns, mesmo "inconvenientes" para os seus signatários, são respeitados e poucos são violados. Quem olha a vida internacional tem à primeira vista a impressão de que nela só domina a violência, uma vez que qualquer violação acarreta graves repercussões na vida dos povos e, em consequiência, produz fortes impactos psicológicos nos indivíduos. Entretanto, essas violações produzem tais impactos porque elas não são comuns e, justamente, representam uma exceção no panorama internacional. Seria difícil e sem qualquer fundo de realidade dizer que os Estados não possuem qualquer norma limitando a sua conduta. Se assim fosse, a vida internacional seria inteiramente anárquica, o que resultaria em impossibilidade da sua organização, ao contrário do que tem acontecido com a criação de organismos internacionais. A própria guerra foi considerada como um dos modos de solução dos conflitos internacionais e regulamentada a sua conduta pelo DIP. ${ }^{41}$

Além disso, a descentralização é uma das características do Direito Internacional, o que não necessariamente o torna menos eficaz ou menos "Direito". O direito

\footnotetext{
${ }^{38}$ MELLO (2001, p. 106)

${ }^{39}$ LUHMANN (1990, p.153)

${ }^{40}$ ACCIOLY (2000, p. 3)

${ }^{41}$ MELLO (2001, p. 104-105)
} 
civil e o penal também possuem diversas diferenças entre si, mas isso não faz com que um seja melhor do que o outro, sendo apenas distintos. ${ }^{42}$

Assim, a partir de uma abordagem dogmática, autores de renome, como Accioly, chegam a afirmar que "seja como for, ao DIP não interessam os motivos reais, econômicos, políticos, sociológicos ou históricos, mas apenas as razões jurídicas que explicam o motivo de sua aceitação pelo homem" ${ }^{\text {,43. }}$.

Nesse sentido, na introdução de um dos capítulos de sua dissertação de mestrado, o professor George Galindo afirma:

Os mecanismos de inserção do Direito Internacional - seja ele costumeiro ou convencional - no ordenamento jurídico de determinado Estado dizem respeito somente ao Direito Interno. Ao Direito Internacional apenas interessa que o Estado não viole qualquer das obrigações pactuadas. Como será explicitado posteriormente, convenções internacionais e regras de direito costumeiro somente confirmam isto ao preceituar que, via de regra, um Estado não pode invocar a violação de seu direito interno a fim de descumprir o Direito Internacional. ${ }^{44}$

Por outro lado, em uma abordagem multidisciplinar, que verifica o contexto em que as normas foram criadas e a razão de sua aplicação no caso concreto, a crítica é mais contundente, embora ainda se imponha a obrigatoriedade do Direito Internacional. Nesse sentido, Rezek, que destaca a falta de paridade e isonomia reais:

Curioso paradoxo: vivemos um momento da história em que internamente desaparecem as ditaduras (algumas agonizam, outras nem mais existem), os Estados se recompõem no espírito democrático e celebram a democracia, para alguns reconquistada e para muitos conquistada pela primeira vez. E quando isso acontece no cenário interno de tantas nações, que temos a impressão amarga de que as coisas desmoronam, de que as referências se perdem, de que o puro e simples exercício de uma política de poder fala mais alto do que o direito, e o faz assumidamente.

Muitos cínicos pretendem lembrar-nos de que o passado não foi tão melhor: nem o poder era menos ambicioso, nem o direito mais eficiente. Assim, não estaríamos hoje diante de uma novidade pelo fato de se afirmar, com eloqüência uma política de poder. Qual é, então, a diferença? A diferença é que no passado não se assumia isto. Havia um mínimo de respeito pela proposição teórica, pela afirmação formal de que buscamos justiça, e de que o fazemos à luz do direito. Na virada do século, pela primeira vez, rasga-se a fantasia de modo aberto, e determinados governantes dizem explicitamente que ali estão para fazer a política a que seu poder real lhes dá "direito". Vimos desaparecer uma situação de contraste ideológico para nos defrontarmos não exatamente com a desordem e o caos, mas com algo pior que a desordem e o caos: a afirmação explícita da negação do direito, o brado arrogante de que a detenção do poder permite sacrificar o direito.

\footnotetext{
${ }^{42}$ ACCIOLY (2000, p. 3)

${ }^{43}$ ACCIOLY (2000, p. 16)

${ }^{44}$ GALINDO (2001, p. 107)
} 
Há hoje uma crise do direito internacional? Ortega y Gasset definia a crise como sendo aquele vazio, aquele espaço inocupado que se produz quando perdemos as referências e os valores do passado e ainda não encontramos outros para tomarem seu lugar. $\mathrm{O}$ que acontece hoje na cena internacional não é bem isso, porque não estamos vendo um espaço vazio. Estamos vendo um espaço ocupado pelo que poderia existir de pior em matéria de ideias e de propostas, e na liderança dos grandes centros de poder. Isto conduz ao colapso do sistema das Nações Unidas. ${ }^{45}$ (grifos nossos)

Surgem, então, diversas teorias a fim de explicar o fundamento e justificar a obrigatoriedade e a universalidade - tidas como características do Direito Internacional -, mas, de certa forma, todas se vinculam a uma das correntes principais: a voluntarista ou positivista e a objetivista. A primeira enxerga a obrigatoriedade como decorrente da vontade do Estado, isto é, sujeita às normas positivadas. Seu maior expoente foi Jellinek, que desenvolveu a teoria da autolimitação do Estado, segundo a qual o próprio Estado é quem estabelece limitações a seu poder absoluto. A crítica que lhe é feita é no sentido da mudança de posição, caso o Estado mude sua vontade. ${ }^{46}$ Por essa razão, autores de renome, como Celso Albuquerque Mello, aderiram a teorias adotadas pela corrente objetivista, como é o caso da teoria do direito natural, in verbis:

A conclusão a que podemos chegar é que as doutrinas voluntaristas, que são no Direito a continuação das filosofias de Espinosa e Hegel, são insuficientes para fundamentar o DI ou qualquer outro ramo da ciência jurídica, uma vez que a vontade só produz efeitos quando preexiste uma norma jurídica lhe atribuindo tais efeitos e, como assinala Jiménez de Aréchaga, tal norma não tem caráter consensual. As doutrinas objetivistas procuram evitar esta crítica; todavia, muitas delas acabam por admitir uma norma superior, cuja justificação é impossível. A melhor concepção, a nosso ver, pelos motivos já expostos, é a do direito natural, e podemos citar as observações de Delbez:

(...) o direito tem por missão fazer reinar a ordem e a justiça (...) inspirandose em um certo ideal de justiça, ele visa a assegurar e manter a ordem social. $\mathrm{O}$ direito tira portanto o seu valor obrigatório do fato de que ele é indispensável à ordem social e que ele é presumido estar conforme a justiça. Se os Estados devem obedecer às regras costumeiras e convencionais, é (...) que elas visam a exprimir e a realizar o "bem comum" da sociedade internacional.

O fundamento assim dado (...) tem um tríplice caráter. Ele é objetivo, porque o bem comum da ordem internacional existe em si e não depende das vontades subjetivas dos Estados. Ele é racional, porque é a razão que o concebe. Ele é transcendente, porque visando a assegurar o bem geral da sociedade interestatal, ele é superior aos Estados que perseguem o seu bem particular (...)

O D. Natural e o Direito Positivo não se opõem; o primeiro se concretiza no segundo. É como assinala Luis García Arias: "o Direito Positivo é o prolongamento necessário do Direito Natural". ${ }^{47}$

\footnotetext{
${ }^{45}$ REZEK (2008b, p. 677)

${ }^{46}$ ACCIOLY (2000, p. 17)

${ }^{47} \operatorname{MELLO}(2001$, p. 144)
} 
A corrente objetivista, como o próprio nome sugere, se baseia em razões que se pretendem objetivas. Conhecida a partir da Escola Espanhola, de Francisco Suárez, visa à aplicação de princípios de direito natural baseados na racionalidade. $\mathrm{O}$ principal deles seria $\mathrm{o}$ de pacta sunt servanda, explícito inclusive na Convenção de Viena sobre o Direito dos Tratados de 1969, que dispõe, em seu artigo 26: "Todo tratado em vigor obriga as partes e deve ser cumprido por elas de boa-fé". 48

A aproximação entre as duas teorias se dá quando entendemos que o consentimento pode ser criativo, mas também pode ser perceptivo, ou seja, é perceptivo quando as normas advêm de um "imperativo ético" e, em razão disso, não estão sujeitos à manipulação ou mera vontade estatal ${ }^{49}$. Assim, uma teoria não tem de ser escolhida em detrimento da outra, pois, ainda que adotemos a teoria voluntarista, é reconhecido que alguns princípios não podem ser alterados a depender da vontade do Estado por serem de consentimento perceptivo.

Outra crítica realizada ao Direito Internacional está relacionada às suas finalidades. Alguns doutrinadores, como Accioly, acreditam que a matéria cumpre bem o seu papel, por acreditarem que a parte mais relevante se refere às transações comerciais, como demonstrado a seguir:

Os acordos comerciais e as organizações internacionais de cunho econômico e financeiro se multiplicam. Os problemas de natureza econômica surgidos no mundo moderno exigem uma cooperação interestatal para a sua solução. A sua importância é tão grande que o comércio internacional é uma das bases sociológicas para a existência do DI. Atualmente todos os autores afirmam que a política externa e a política interna estão entrelaçadas de tal modo que não se sabe onde uma começa e a outra acaba. (...) Pode-se lembrar a frase de Jacques Attali (Fraternités, 1999): "a guerra é e será uma continuação do mercado por outros meios". 50

Cabe ainda lembrar que o referido autor classifica o comércio internacional, juntamente com a pluralidade de Estados soberanos e com os princípios jurídicos coincidentes entre eles, como um dos pressupostos para a existência do Direito Internacional. ${ }^{51}$ Outra parte da doutrina, no entanto, considera que o Direito Internacional não atinge seus fins, pois entende que o ideal seria alcançar a paz, conforme critica Rezek:

Não é possível admitir que devemos nos contentar com o sucesso do direito internacional naquilo que ele tem de periférico, no sentido de não essencial. $\mathrm{O}$ direito internacional tem realizado prodígios fazendo evoluir normas do

\footnotetext{
${ }^{48}$ ACCIOLY (2000, p. 16-17)

${ }^{49}$ REZEK (2008a, p. 3)

${ }^{50}$ MELLO (2001, p. 46)

${ }^{51}$ MELLO (2001, p. 68)
} 
direito do trabalho, do direito penal, ou do direito relacionado com vários aspectos da atividade econômica e da integração. Mas nada disso é central. A parte central é aquela que garante a paz entre os membros da comunidade e sua segurança coletiva à luz do direito e em nome do ideal de justiça. Foi para isso que se criou a Organização das Nações Unidas, não foi para atividades periféricas. Quando terminou a guerra do Iraque, entre outros disparates que todos ouvimos, esteve a afirmação de que a ONU não se encontrava alijada, humilhada, desprezada nas suas prerrogativas, nas suas funções. Não. Ela tinha seu papel, ela teria, sim, algo que fazer, e que consistiria em administrar o resíduo da guerra, de modo a socorrer as pessoas com ajuda humanitária e hospitalar. O Brasil lembrou na época (e esse foi um dos grandes momentos da diplomacia brasileira) que a Organização não foi criada para administrar as ruínas de uma guerra que ela não conseguiu evitar. Não, não foi para isso. Não foi para dar assistência humanitária às vítimas da invasão e da ocupação militar estrangeira que a ONU foi criada. Até porque no momento em que a Organização realizar seu fundamental objetivo de prover paz e segurança para todos, em nome do direito, e com justiça, não haverá mais espaço para assistências humanitárias e outras caridades. Tudo isso hoje é subproduto de uma injúria fundamental representada pelo fracasso da organização no cumprimento dos seus objetivos básicos. Não se pode redimir a organização nem sublimar o seu essencial colapso dando-lhe funções beneméritas, distantes da sua destinação principal. $^{52}$

De fato, a crítica é pertinente, embora exacerbada. O Direito Internacional tem, sim, como principal objetivo evitar a guerra. No entanto, as diversas ações que são regulamentadas pelo Direito Internacional, e rotineiramente ocorrem sem que o mundo volte suas atenções para lá, não devem ser desprezadas. Caso o Direito não interviesse e pairasse a autotutela entre os Estados, a situação estaria muito mais caótica, com diversas outras guerras em andamento. Por óbvio, reconhecemos que é necessária a melhora. Essa, no entanto, só será obtida a partir do respeito às normas do Direito Internacional.

\subsection{AS NORMAS DE DIREITO INTERNACIONAL E A ADESÃO A ELAS}

Para que se entenda como funcionam as normas do direito internacional, devemos analisar primeiramente quais são suas fontes de maneira geral. Afinal, ao contrário do que ocorre normalmente no direito interno, o Direito Internacional não possui um órgão centralizado legitimado a legislar ou julgar, o que não deve ser visto como razão para diminuir sua eficácia, como já visto anteriormente. Não se deve, no entanto, ter um conceito estático de fonte, como se o direito fosse dado e imutável. Como ciência social que é, o direito

\footnotetext{
${ }^{52}$ REZEK (2008b, p. 678)
} 
muda juntamente com a sociedade, que está em constante transformação, o que o torna mais complexo. $^{53}$

Na conceituação de Accioly, "por fontes do DIP entendemos os documentos ou pronunciamentos dos quais emanam os direitos e os deveres das pessoas internacionais; são os modos formais de constatação do direito internacional" ${ }^{, 5}$. O autor ainda destaca que, a depender da escola adotada como fundamento do internacionalismo - qual seja, a voluntarista ou a objetivista - serão consideradas apenas as fontes positivadas ou não. O referido doutrinador se coloca em uma posição intermediária e muito razoável, segundo a qual as fontes positivadas seriam tidas como fontes formais e aquelas que decorrem de um aspecto fundamental, racional são consideradas fontes materiais, independente da aceitação dos Estados. $^{55}$

No que diz respeito às fontes materiais, diversos autores, como Celso Albuquerque de Mello, consideram que elas sejam apenas os aspectos histórico, social e econômico que influenciam as fontes formais. ${ }^{56}$ De toda sorte, o autor mencionado destaca que a concepção voluntarista, apesar de simplificar a questão e garantir a soberania estatal, não consegue explicar a contento a eficácia dos costumes internacionais - os quais, embora constituam a fonte de maior parte das obrigações internacionais, seriam apenas expressão da vontade tácita dos Estados. Então, o doutrinador classifica as fontes formais como meios de comprovação e as fontes materiais como auxiliares da interpretação das formais. ${ }^{57}$

Ao serem criados os tribunais internacionais, eles precisavam mostrar com base em que seriam criadas suas decisões. ${ }^{58}$ Assim, primeiramente o Tribunal Internacional de Presas e depois o Estatuto da Corte Internacional de Justiça arrolam as fontes de direito que aplicarão, sendo esse último preferido porque não prevê hierarquia entre as fontes, ou seja, uma fonte é autônoma em relação às demais. ${ }^{59} \mathrm{O}$ artigo 38 do Estatuto dispõe:

I - A Corte, cuja função é decidir de acordo com o Direito Internacional as controvérsias que lhe forem submetidas, aplicará:

a) as convenções internacionais, quer gerais, quer especiais, que estabeleçam regras expressamente reconhecidas pelos Estados litigantes.

b) o costume internacional, como prova de uma prática geral aceita como sendo o direito;

c) os princípios gerais de direito reconhecidos pelas nações civilizadas;

\footnotetext{
${ }^{53}$ HÄBERLE (2003, p. 124 et seq.)

${ }^{54}$ ACCIOLY (2000, p. 19)

${ }^{55}$ ACCIOLY (2000, p. 19)

${ }^{56}$ MELLO (2001, p. 191)

${ }^{57}$ MELLO (2001, p. 193)

${ }^{58}$ REZEK (2008a, p. 9)

${ }^{59}$ MELLO (2001, p. 194)
} 
d) sob ressalva da disposição ao art. 59, as decisões judiciárias e a doutrina dos publicistas mais qualificados das diferentes nações, como meio auxiliar para a determinação das regras de direito.

II - A presente disposição não prejudicará a faculdade da Corte de decidir uma questão "ex aequo et bono", se as partes com isto concordarem. ${ }^{60}$

Os doutrinadores ainda tratam dos atos unilaterais e das decisões das organizações internacionais como se esses não estivessem abarcados pelo rol do Estatuto da Corte Internacional de Justiça. Ora, é possível que os referidos atos jurídicos sejam cumpridos sob a alegação de que são utilizados, na verdade, os princípios gerais encontrados nessas declarações, e não as declarações em si. No entanto, entendemos que, independente da nomenclatura que lhe é dada, toda manifestação de vontade por parte de um Estado se enquadraria na letra "a" do rol transcrito acima, inclusive com as vedações, por exemplo, de violação ao ius cogens, como veremos mais adiante. Ainda que não esteja totalmente de acordo com esse argumento, Rezek chega a mencioná-lo. ${ }^{61}$

Todo ato jurídico no Direito Internacional deve possuir os elementos a seguir, para que seja válido: capacidade do autor; imputação do ato ao sujeito de Direito Internacional feita por um órgão; manifestação de vontade, prevalecendo a declaração explícita ou implícita à vontade real; objeto lícito e possível. Cabe ainda lembrar que, no tocante à capacidade das partes, os Estados possuem capacidade ilimitada, enquanto que as organizações internacionais são limitadas apenas à matéria para que foram criadas, segundo a teoria dos poderes implícitos. ${ }^{62}$

De igual maneira, também os tratados necessitam desses elementos como requisito de validade. Notoriamente, os acordos internacionais são dotados de formalidade. Embora acordos orais também possam ser dotados de obrigatoriedade, os tratados de Direito Internacional se caracterizam pela escrita, pela documentação da vontade das partes, sendo, inclusive, esse atributo um diferencial entre as normas contratuais e as costumeiras. ${ }^{63}$

Os tratados são considerados atualmente a fonte mais importante do DI, não só devido à sua multiplicidade mas também porque geralmente as matérias mais importantes são regulamentadas por eles. Por outro lado, o tratado é hoje considerado a fonte do DI mais democrática, porque há participação direta dos Estados na sua elaboração. ${ }^{64}$

\footnotetext{
${ }^{60}$ CORTE INTERNACIONAL DE JUSTIÇA (1945, art. 38)

${ }^{61}$ REZEK (2008a, p. 137)

${ }^{62} \operatorname{MELLO}(2001$, p. 195)

${ }^{63}$ REZEK (2008a, p. 17) Usaremos, no presente trabalho, a definição em sentido amplo de tratado, sem nos importarmos com a terminologia específica que diferencia, por exemplo, um protocolo de um convênio. No entanto, as características aqui expostas são essenciais a todos os tipos de tratados.

${ }^{64}$ BEDJAOUI apud MELLO (2001, p. 200)
} 
Em razão disso, foram formadas duas Convenções, em Viena, a fim de regulamentar a matéria dos tratados, sendo a segunda, na verdade, decorrência de uma necessidade que havia sido prevista durante os estudos da primeira: a necessidade de regulamentar não só os tratados entre Estados, mas também aqueles que envolvessem as organizações internacionais, sendo essas consideradas como aquelas organizações interestatais, ou seja, formadas por Estados soberanos, independente de vontade autônoma da de seus membros, excluídas as não-governamentais, as multinacionais, as supranacionais, como a União Européia, ou o indivíduo. ${ }^{65}$

Assim, na Convenção de 1969, aquela que tratava dos tratados apenas entre Estados, reconheceu-se que as organizações internacionais necessitavam de um regime jurídico diverso, em razão de suas peculiaridades. Esse regime não foi tema daquela Convenção em si, sob a alegação de que isso tornaria a Convenção complexa a ponto de dificultar sua ratificação. A importância dessa discussão foi classificar as organizações como sujeitos de direito, pois, a partir do momento que lhes é reconhecida a capacidade de celebrar tratados, elas se diferenciam de meros acordos multilaterais. Afinal, apenas dessa maneira elas seriam capazes de assumir obrigações e direitos. ${ }^{66}$

Surge, então, em 1986, uma Convenção análoga à de 1969, o que facilitou, inclusive, o conhecimento do conteúdo da norma que, em grande parte, já vinha sendo colocada em prática. Como expõe Cançado Trindade:

A diferença somente aparece nos pontos que dizem respeito à especificidade do treaty-making power das organizações internacionais.

Uma comparação entre os principais dispositivos dos dois tratados deixa bem clara a congruência existente entre elas. $\mathrm{O}$ artigo $1^{\circ}$ de cada uma, por exemplo, cuida da competência em razão da pessoa (ratione personae), ou seja, delimita quais os sujeitos de direitos obrigados por suas normas. No caso da Convenção de 1969, o texto é claro ao mencionar somente os Estados. Já a Convenção de 1986 menciona duas hipóteses: tratados celebrados entre Estados e organizações internacionais e tratados celebrados entre organizações internacionais. $\mathrm{O}$ artigo $2^{\circ}$ de ambas as convenções, por sua vez, cuida da competência ratione materiae, definindo o que se deve entender por "tratado". A Convenção de 1969 define "tratado" como acordo por escrito entre dois ou mais Estados. A definição da Convenção de 1986 é quase idêntica: "tratado" é acordo por escrito entre um ou mais Estados e uma ou mais organizações internacionais ou entre organizações. Da mesma forma, o art. $4^{\circ}$ dos dois instrumentos jurídicos internacionais cuida da competência ratione temporis, prescrevendo a aplicação da convenção desde o momento em que esse texto legal entrou em vigor para o Estado que a assinou, no caso da Convenção de 1969, ou ainda desde o momento que a organização a assinou, no caso da Convenção de $1986 .{ }^{67}$

\footnotetext{
${ }^{65}$ TRINDADE (2003, p. 187)

${ }^{66}$ TRINDADE (2003, p. 182-183)

${ }^{67}$ TRINDADE (2003, p. 185)
} 
Por outro lado, as similitudes entre as duas convenções fez com que diversos países vissem como desnecessária a ratificação da Convenção de 1986, embora tivessem já ratificado a de 1969, inclusive o Brasil, que a assinou, mas ainda nem enviou a matéria ao Congresso para aprovação - por isso a Convenção ainda não obteve o quórum para entrar em vigor. Nosso país, segundo parecer do Ministério das Relações Exteriores, entende, ainda, que não deve haver uma norma geral para as organizações internacionais, tendo em vista que sua limitação se dará em razão da matéria, o que mudaria segundo a especificidade de cada organização. $^{68}$

Além disso, a Convenção de 1986 traz, como procedimento de solução judicial, arbitragem ou conciliação em caso de conflito, a intervenção da Corte Internacional de Justiça como uma das alternativas. Diversos estados consideram que haveria, assim, uma intervenção em sua soberania, em sua jurisdição, o que demandaria do governante um grande esforço para aprovação no legislativo local, sendo que, a parte da Convenção que lhe convém já é aplicada a título de direito costumeiro ou por se encontrar presente na Convenção de $1969 .{ }^{69}$

Os Estados compreenderam que existem certos problemas que não podem ser resolvidos por eles sem a colaboração dos demais membros da sociedade internacional. As organizações internacionais são as resultantes deste fator e é dentro delas que mais se sente a atuação das ideologias ou blocos sócioculturais nas soluções dos mais diferentes problemas. É a nossa época caracterizada como sendo a do associacionismo internacional. ${ }^{70}$

Assim, a sociedade internacional caminha para a formação de uma comunidade internacional, a partir da necessidade de cooperação e assistência entre os Estados e os demais sujeitos de Direito Internacional, embora autores de renome, como Celso de Mello, tenham dificuldade em enxergar essa transição. ${ }^{71}$

Esse sociólogo [Ferdinand Tonnies], levando em consideração a "intensidade do vínculo psicológico" nos grupos sociais, os classificou em comunidade e sociedade. A comunidade apresentaria as seguintes características: formação natural; vontade orgânica (...); e os indivíduos participariam de maneira mais profunda na vida em comum. A comunidade é uma criação de cooperação natural "anterior a uma escolha consciente de seus membros"(Harry Liebersohn - "Fate and Utopia in German Sociology, 1870-1923", 1988). A sociedade já possuiria caracteres diferentes: formação voluntária, vontade refletida (seria produto do pensamento, dominada pela ideia de finalidade e tendo como fim supremo a felicidade); e os indivíduos participariam de maneira menos profunda na vida em comum. A

\footnotetext{
${ }^{68}$ TRINDADE (2003, p. 203)

${ }^{69}$ TRINDADE (2003, p. 193)

${ }^{70}$ MELLO (2001, p. 45)

${ }^{71}$ MELLO (2001, p. 47)
} 
comunidade estaria regida pelo direito natural, enquanto a sociedade se encontraria sob o contrato. ${ }^{72}$

Algumas características são destacadas ao se observar a situação social em que se encontram os Estados atualmente, independente da classificação dessa, quais sejam: é um grupo universal, paritário, aberto, que não possui uma organização institucional centralizadora e seu direito é originário. ${ }^{73}$

Os países e doutrinadores que defendem a revisão do Direito Internacional, sob a alegação de que as normas desse ramo do Direito atenderiam apenas a interesses dos Estados mais poderosos, alegam que as diversas culturas não são respeitadas e que "a universalidade do direito é, na verdade, a racionalidade do direito ocidental." ${ }^{, 74}$ Assim, o Direito Internacional Clássico teria como base geográfica o direito europeu, como ordenação ético-religiosa o cristianismo, como fonte econômica o mercantilismo e como finalidade política o imperialismo, pelo que favoreceria ao neocolonialismo. ${ }^{75}$

No entanto, algumas características são notórias e percebidas a partir de uma análise fática, independente da reivindicação dos países subdesenvolvidos de políticas compensatórias para que lhes seja assegurada uma igualdade material, e não apenas formal:

Pertencendo ao sistema internacional contemporâneo: a) ter ocorrido um incremento nas relações econômicas no sentido do estabelecimento de um mercado mundial; b) as informações são transmitidas instantaneamente; c) 0 volume de informações e o deslocamento das pessoas têm aumentado; d) devido às armas de destruição em massa há um campo estratégico unificado; e) os Estados participam de um grande número de organismos internacionais ${ }^{76}$

De qualquer maneira, a formação da sociedade internacional possui duas correntes explicativas: a positivista e a jusnaturalista. Enquanto a primeira é defendida por Cavaglieri e justifica a sociedade internacional a partir da vontade dos Estados, a segunda enxerga o homem como um ser social, que não poderia viver fora de um grupo. Del Vecchio defende a teoria jusnaturalista com base na unidade do gênero humano, comprovada pela possibilidade de procriação entre pessoas de diversas etnias. Não se trata apenas de escolher uma dentre as teorias apresentadas. Não se pode defender a teoria positivista, sob pena de se

\footnotetext{
${ }^{72}$ MELLO (2001, p. 47)

${ }^{73}$ MELLO (2001, p. 48)

${ }^{74}$ CHEMILLIER-GENDREAU apud MELLO (2001, p. 51)

${ }^{75}$ BEDJAOUI apud MELLO (2001, p. 53)

${ }^{76}$ MERLE apud MELLO (2001, p. 55)
} 
aceitar que algum Estado "escolha" não participar da sociedade internacional e, com esse argumento, violar normas que independem de aceitação. ${ }^{77}$

Ora, o Direito Internacional é formado, em sua essência, por normas costumeiras e por princípios gerais - os quais, como já foi dito, também são arrolados no Estatuto da Corte Internacional de Justiça como fontes, sem haver hierarquia entre eles e as normas decorrentes da expressão da vontade estatal.

O apelo a princípios que estão acima do Direito Positivo é feito constantemente na prática internacional, como ocorre nas Convenções de Genebra de 1949, que declaram que os casos não previstos na sua regulamentação estão sujeitos, entre outras limitações, às "leis de humanidade e às exigências da consciência pública"; no mesmo sentido está o art. 51 da Carta da ONU, que qualifica o direito de legítima defesa de "direito inerente". Pode-se lembrar que o D. Natural está nas raízes da noção do "jus cogens" que foi consagrado na convenção de Viena sobre direito dos tratados. ${ }^{78}$

Desse modo, desde o século XVII, Grocius introduz a ideia de direito cogente, ainda que sob a forma de ius divinum. De toda sorte, eram normas imperativas, "valores fundamentais" impostos aos Estados, principalmente após os horrores praticados na Segunda Guerra Mundial, a fim de garantir uma "ordem pública". ${ }^{79}$

Da mesma forma que aos indivíduos são impostas regras independente de sua vontade, no plano interno, os Estados estão submetidos a algumas normas cogentes no plano internacional, e assim funcionam todos os sistemas normativos. A Convenção de Viena de 1969 sobre tratados não foi ratificada por alguns países por trazer, em seu artigo 53, a previsão de normas imperativas, que foram consideradas como um risco à soberania estatal, sob a seguinte definição: "uma norma aceita e reconhecida pela comunidade internacional dos Estados em sua totalidade, como uma norma da qual não se admite derrogação e que só pode ser modificada por uma nova norma de direito internacional" ${ }^{\prime 80}$. A referida Convenção traz, ainda, a previsão de nulidade do tratado, caso ele viole alguma norma de ius cogens, mesmo que a criação dessa seja posterior ao tratado.

A questão seguinte seria identificar quais são essas normas. O que a unanimidade dos doutrinadores aceitam é a proibição do uso da força nas relações internacionais, talvez pelo contexto em que passaram a ser admitidos, após as Guerras Mundiais. Concordamos, no entanto, com o espanhol Carrilo Salcedo, que, além daquela, traz outras normas de ius cogens, quais sejam: a igualdade entre os Estados e o princípio da não

\footnotetext{
${ }^{77}$ MELLO (2001, p. 48)

${ }^{78}$ MELLO (2001, p. 145)

${ }^{79}$ PEREIRA e QUADROS apud MELLO (2001, p. 75-76)

${ }^{80}$ CONVENÇÃO DE VIENA (1969, art. 53)
} 
intervenção, a autodeterminação dos povos e os direitos fundamentais do homem. ${ }^{81}$ Assim também parece entender a Corte Interamericana de Direitos Humanos:

Desde sua primeira sentença, esta Corte destacou a importância do dever estatal de investigar e punir as violações de direitos humanos. A obrigação de investigar e, se for o caso, julgar e punir adquire particular importância ante a gravidade dos crimes cometidos e a natureza dos direitos ofendidos, especialmente em vista de que a proibição do desaparecimento forçado de pessoas e o correspondente dever de investigar e punir aos responsáveis há muito alcançaram o caráter de jus cogens. ${ }^{82}$

O fundamento do ius cogens, bem como dos costumes internacionais de modo geral, encontram guarida também na teoria da vontade coletiva, classificada, inclusive como uma teoria voluntarista. Segundo Triepel, os Estados manifestariam suas vontades expressamente por meio de tratados-leis e tacitamente por meio dos costumes. A crítica, além daquelas comuns às teorias voluntaristas, estaria em saber qual é implicitamente a vontade dos Estados, para saber efetivamente as normas costumeiras e as de ius cogens. ${ }^{83}$

A norma costumeira sendo geral, torna-se obrigatória para todos os Estadosmembros da sociedade internacional, mesmo aqueles que não manifestaram a sua vontade no sentido de aceitação. Devemos repetir a crítica de Borchard, que observa: a) se o DI repousasse no consentimento, ele seria uma simples obrigação moral, uma vez que o Estado poderia retirar sua vontade quando bem entendesse; b) que a vontade estatal só é necessária para a nova legislação internacional (codificação) através de tratados internacionais; c) a obrigação de o Estado respeitar o costume "constitui uma condição de sua admissão e do seu reconhecimento contínuo como membro da família das nações. ${ }^{84}$

Costumes diversas vezes são expressos nos tratados não porque haja hierarquia entre eles e o tratado valha mais, mas, sim, porque o tratado, como forma expressa e positivada, tem a sua comprovação facilitada. Afinal, tem de se mostrar que os elementos do costume estão presentes para que ele seja considerado obrigatório. ${ }^{85}$

A norma jurídica costumeira, nos termos do Estatuto da Corte, resulta de "uma prática geral aceita como sendo o direito". Essa expressão dá notícia do elemento material do costume, qual seja a prática - a repetição, ao longo do tempo, de certo modo de proceder ante determinado quadro de fato -, e de seu elemento subjetivo, qual seja a convicção de que assim se procede não sem motivo, mas por ser necessário, justo, e consequentemente jurídico. ${ }^{86}$

\footnotetext{
${ }^{81}$ SALCEDO apud MELLO (2001, p. 75-76)

${ }^{82}$ CORTE Interamericana de Direitos Humanos. Caso Gomes Lund e Outros (Guerrilha do Araguaia) vs. Brasil. Sentença. 24 de novembro de 2010. Disponível em: 〈http://www.corteidh.or.cr/casos.cfm?idCaso=348>. Acesso em: 12 jan 2011.

83 TRIEPEL apud MELLO (2001, p. 137)

${ }^{84}$ BORCHARD apud MELLO (2001, p. 192-193)

${ }^{85}$ REZEK (2008a, p. 124-125)

${ }^{86}$ REZEK (2008a, p. 118)
} 
O autor destaca, ainda, que o elemento material do costume pode versar sobre uma ação ou uma omissão do sujeito de Direito Internacional. No tocante ao tempo necessário de prática, para que ela seja considerada como um costume, ele destaca que a velocidade das relações contemporâneas, em decorrência da globalização e da industrialização, fez com que uma prática fosse tida por costume em um período muito mais curto de tempo do que antes, quando eram exigidos séculos. ${ }^{87}$ Carla Ventura, ao explanar acerca da criação do comércio internacional, exemplifica muito bem o que seria a formação de um costume, in verbis:

O direito dos mercadores é, assim, tão antigo quanto o próprio comércio. Ao lado dessas regras, observou-se o desenvolvimento de práticas comerciais difundidas e aceitas, cuja violação implicava a exclusão do comerciante do respectivo mercado. A este conjunto de regras denominou-se lex mercatoria. A generalização da prática explica o nascimento das regras e as condutas isoladas se ampliam até que, por força espontânea, passam a exercer pressão sobre a coletividade, criando e formalizando normas do comércio internacional, diferentemente das normas estatais. A criatividade inerente à lex mercatoria se torna realidade com o comportamento reiterado dos interessados diante dos mesmos fatos ou fatos novos, movidos pelo consenso que automaticamente vai se tornando uma regra. ${ }^{88}$

Alguns costumes advêm de tratados, quando, então, passam a ser obrigatórios para todos os Estados. ${ }^{89}$ Com isso, os efeitos do tratado deixariam de ser inter partes e passariam a ser erga omnes. O fundamento dos costumes é o mesmo dos tratados, qual seja: o princípio geral de direito que estabelece consuetudo est servanda e pacta sunt servanda. ${ }^{90}$ Assim, podemos perceber como as fontes de Direito Internacional estão inter-relacionadas entre si.

Estes princípios são poucos e, segundo Sereni, podem ser considerados "princípios constitucionais" [da sociedade internacional]: a) princípio que estabelece ser o tratado e o costume fonte do DI ("consuetudo est servanda" e "pacta sunt servanda"); b) o princípio da independência do Estado; c) o princípio da continuidade do Estado, apesar das modificações que ele venha a sofrer. ${ }^{91}$

Os princípios, por sua vez, são de extrema relevância para o Direito Internacional, inclusive na solução de causas que não haviam sido previstas pelas normas positivadas. A existência de valores comuns é um dos fatores que faz com que os Estados se relacionassem. Assim, são pressupostos de base sociológica da existência do próprio Direito

\footnotetext{
${ }^{87}$ REZEK (2008a, p. 119)

${ }^{88}$ VENTURA (2010, p. 93)

${ }^{89}$ MELLO (2001, p. 211)

${ }^{90}$ MELLO (2001, p. 209)

${ }^{91}$ SERENI apud MELLO (2001, p. 192)
} 
Internacional: a pluralidade de Estados soberanos, o comércio internacional e outras matérias de interesse comum e os princípios jurídicos coincidentes. ${ }^{92}$

Trataremos brevemente da jurisprudência e doutrina, tendo em vista que o próprio Estatuto da Corte Internacional de Justiça não as considera como fonte em si, mas, sim, como instrumento de compensação. Mais do que no direito interno, esses instrumentos são muito relevantes, considerando que grande parte das normas internacionais são costumeiras ou principiológicas e, com isso, sem estarem transcritas, têm sua interpretação dificultada. ${ }^{93}$

A jurisprudência levada em consideração em âmbito internacional é, por óbvio, aquela produzida pelas Cortes internacionais, ainda que sob a forma de pareceres, sendo desconsideradas aquelas de caráter doméstico. A doutrina, evidentemente, quase nunca é unânime em relação a uma questão. Isso faz com que os argumentos de uma maioria tenham mais força, pois, uma tese que tenha reunido diversas correntes doutrinárias merece destaque. $^{94}$

O segundo parágrafo do artigo 38 do Estatuto da Corte Internacional de Justiça prevê, ainda, a analogia e a equidade como formas de preencher lacunas caso inexista norma a ser aplicada ou caso a norma existente leve a uma decisão notoriamente injusta. Isto é, não são, na verdade, métodos interpretativos, o que torna sua aplicação ainda mais rara. Destacase, também, a previsão expressa da necessidade de consentimento das partes para solucionar a questão por meio da analogia ou da equidade. ${ }^{95}$

Os Estados só violam o DIP quando a vantagem disto é maior do que o custo dentro do "contexto de sua política exterior"; b) os Estados necessitam possuir confiança dos demais Estados para realizarem a sua própria política externa, daí ser necessário que respeitem o DIP; c) há interesse dos Estados em manterem as relações internacionais dentro de certa ordem; d) os Estados têm medo de represálias; e) os Estados obedecem ao DIP por hábito e imitação. $^{96}$

Dessa forma, é interessante notar que são essas as razões que levam os Estados a violarem as normas - sejam aquelas que lhe são impostas ou até mesmo aquelas com que concordaram. Sabendo quais são, podemos evitar que isso se repita.

\footnotetext{
${ }^{92}$ MELLO (2001, p. 68)

93 REZEK (2008a, p. 141 et seq.)

${ }^{94}$ REZEK (2008a, p. 143 et seq.)

95 REZEK (2008a, p. 145 et seq.)

${ }^{96}$ HENKIN apud MELLO (2001, p. 77)
} 


\section{CAPÍTULO 2 - DIREITO CONSTITUCIONAL BRASILEIRO}

No segundo capítulo, busca-se uma visão mais voltada para o plano interno. Analisaremos, primeiramente, quais foram as influências externas na história constitucional brasileira e a maneira como o Brasil vem tratando, desde a época colonial, o Direito Internacional, principalmente considerando esse tratamento nos dias atuais - não só a partir do advento da Constituição de 1988, mas também com as mutações constitucionais que a seguiram. A título comparativo, quando for relevante, mostraremos também de que forma outros países tratam a mesma matéria - se de modo semelhante ou divergente.

Inserido nesse contexto, analisa-se a questão da separação entre os Poderes e qual é a diferença prática que uma efetiva aplicação dessa teoria traria ao internacionalismo. Questionamos também se o Brasil preza pela concretização dos princípios que apresenta em sua Carta Magna, dentre os quais está a interdependência entre os Poderes. Poderia um dos Poderes se sobrepor aos demais, independente da previsão constitucional de suas competências? Caso isso ocorresse, como poderíamos identificar essa violação e quais medidas deveriam ser adotadas para sanar esse vício?

É nessa seção do presente trabalho que trataremos também de um dos temas mais relevantes atualmente no Direito Internacional: os direitos humanos. A análise aqui realizada não pretende esgotar a temática, cuja extensão aplicativa vai além da imaginação dos doutrinadores e a cada dia se revela mais proeminente. Intentaremos analisar apenas algumas das principais medidas adotadas pelo Brasil para efetivação dos direitos humanos, seja no plano do contratualismo internacional, seja no plano legislativo.

A partir de então, veremos como o Judiciário se manifesta em relação aos conflitos normativos entre o plano interno e o externo, encontrados inclusive na proteção ao indivíduo, uma vez que, em decorrência de alguns tratados humanistas ratificados pelo Brasil, a questão foi colocada sob a forma de casos concretos aos órgãos jurisdicionais como se tivesse de ser escolhido um dos objetos a ser defendido em detrimento do outro: ou os direitos humanos, ou o internacionalismo. Veremos que a proteção a um deles não é excludente da proteção ao outro, mas, sim, elas podem ser aliadas para uma otimização de esforços, principalmente no contexto de cooperação internacional em que o Brasil visa à sua inserção. 


\subsection{O HISTÓRICO DA RELAÇÃO ENTRE O DIREITO (CONSTITUCIONAL) BRASILEIRO E O DIREITO INTERNACIONAL}

A história brasileira começa a ser contada a partir do seu "descobrimento" por Portugal, o que, desde então, nos demonstra como as contingências externas foram importantes ao desenrolar dos acontecimentos neste país. À época, vigiam na metrópole as Ordenações Afonsinas, as quais, então, passam a ser o direito aplicado também no Brasil. As ordenações eram compilações jurídicas que buscavam a reunião em um mesmo diploma da legislação referente a uma temática - no caso, o direito privado - para facilitar sua aplicação. ${ }^{97}$

Não se sabe ao certo desde quando as Ordenações Afonsinas estavam em vigor, já que não havia, naquela época, atos de publicação dos atos legislativos. O que sabemos é que, depois dela, vieram as Ordenações Manuelinas e, por fim, as Filipinas. Basicamente uma se diferenciava da outra apenas no sentido de atualização, com pequenas novidades, como, por exemplo, a criação da Casa da Suplicação como órgão interpretativo. ${ }^{98}$

Além das Ordenações, outras normas foram criadas para regulamentar especificamente as situações da colônia, como as cartas de doação, os forais - que criavam as capitanias hereditárias -, os regimentos dos governadores, os alvarás e as cartas régias. No tocante ao internacionalismo, o Brasil também seguia a prática portuguesa, sendo, então, subordinado também à Inglaterra, de quem Portugal era aliado. ${ }^{99}$

Com a independência do Brasil em relação a Portugal em 1822, não houve uma ruptura imediata do nosso sistema jurídico. Só no campo político essa ruptura foi quase que imediata com a Constituição outorgada de 1824.(...) No campo das relações estritamente civis somente em 1916 é que foi promulgado o nosso Código Civil, entrando em vigência no dia $1^{\circ}$ de janeiro de 1917. Portanto, as Ordenações Filipinas permaneceram com eficácia quase plena por quase 315 anos, ou seja, de 1603 até 1916. Nesse período elas regularam as relações civis na época colonial, e, após nossa independência, passando pelos dois governos imperiais, para alcançar a república e sobreviver até o século XX. ${ }^{100}$

Assim, o Brasil só passa a ter maior importância, deixando de ser tratado como uma mera colônia de exploração mercantil a partir de 1808, com a decretação do Bloqueio

\footnotetext{
97 ANDRÉ ([2005?], p. 2)

${ }^{98}$ ANDRÉ ([2005?], p. 6)

${ }^{99}$ ANDRÉ ([2005?], p. 10)

${ }^{100}$ ANDRÉ ([2005?], p. 11)
} 
Continental por Napoleão Bonaparte, o que levou a Corte Portuguesa a fugir para o Rio de Janeiro. Tanto é assim que, em 1815, o Brasil foi elevado à categoria de Reino Unido. ${ }^{101}$

Os portugueses, em 1820, na Revolução do Porto, se revoltam e exigem o retorno da Corte a Portugal. Dentre as reivindicações lusitanas encontrava-se uma constituição liberal, ou seja, contra o absolutismo, que limitasse os poderes do rei - ideário esse decorrente da Revolução Francesa. ${ }^{102}$

O constitucionalismo se opunha, ideologicamente, ao absolutismo, razão por que "não era qualquer regime, não era, do ponto de vista material e neutro, qualquer sistema constitucional, mas, sim, um sistema político em que houvesse separação de poderes e em que houvesse também a asseguração dos direitos individuais, portanto, um regime ou sistema político de liberdades. Quando, então - prossegue o autor do clássico A Lei e a Constituição -, se exigia um regime constitucional, o que se queria era um regime liberal, e constitucionalismo não era dar uma Constituição qualquer, e sim uma Constituição liberal, fundada naqueles pressupostos clássicos [art. 16 da Declaração dos Direitos do Homem e do Cidadão, de 1789: "Toda sociedade na qual a garantia dos direitos não for assegurada, nem a separação dos poderes determinada, não tem Constituição"]. ${ }^{103}$

Dessa maneira, D. João VI volta a Portugal. As exigências dos portugueses, por sua vez, continuam, incluindo a recolonização do Brasil, o que leva D. Pedro a declarar a independência do país em 7 de setembro de 1822. Antes mesmo, em junho, já havia sido convocada uma Assembleia Constituinte. Demonstrando a crença da época de que a Constituição era a forma de se lutar contra o absolutismo, a Constituinte apresentou um anteprojeto que ficou conhecido como "Constituição da Mandioca", em razão do voto censitário a partir da quantidade de mandioca produzida pelo cidadão. ${ }^{104}$ Previa, inclusive a subordinação do imperador ao Legislativo e, além disso, adotava princípios como o da soberania nacional e do liberalismo econômico, sendo também xenofóbica, principalmente no sentido da lusofobia. ${ }^{105}$

Isso fez com que D. Pedro I dissolvesse a Assembleia e outorgasse, em 25 de março de 1824, a primeira Constituição brasileira ${ }^{106}$, a qual dispunha dos seguintes elementos:

(...) Texto se inicia com a norma institucional do Império do Brasil como associação de todos os cidadãos brasileiros, os quais formam uma nação livre, que não admite com qualquer outra laço algum de união ou federação que se oponha à sua independência (art. $1^{\circ}$ ). O seu território é dividido em províncias, na forma em que se achavam estas, as quais poderão ser subdivididas como pedir o bem do Estado (art. $2^{\circ}$ ). O seu governo é

\footnotetext{
${ }^{101}$ KOSHIBA; PEREIRA (2003, p. 167 et seq.)

${ }^{102}$ KOSHIBA; PEREIRA (2003, p. 177-178)

${ }^{103}$ BITAR apud MENDES; COELHO; BRANCO (2007, p. 151)

${ }^{104}$ KOSHIBA; PEREIRA (2003, p. 200)

${ }^{105}$ KOSHIBA; PEREIRA (2003, p. 217)

${ }^{106}$ KOSHIBA; PEREIRA (2003, p. 219)
} 
monárquico e hereditário, constitucional e representativo (art. $3^{\circ}$ ), tendo como dinastia imperante a de Dom Pedro I, Imperador e Defensor Perpétuo do Brasil (art. $4^{\circ}$ ) e a Religião Católica Apostólica como a Religião do Império, podendo ser permitidas todas as outras religiões, com seu culto doméstico ou particular, em casas para isso destinadas, sem forma alguma exterior de templo (art. $5^{\circ}$ ).

A divisão e harmonia dos poderes políticos é o princípio conservador dos direitos dos cidadãos e o mais seguro meio de fazer efetivas as garantias que a Constituição oferece (art. $9^{\circ}$ ), sendo os Poderes estatais reconhecidos pela Constituição do Império (art. 10), o Poder Legislativo, delegado à Assembleia Geral, com a sanção do Imperador (art. 13), composta de duas câmaras, a Câmara dos Deputados e a Câmara de Senadores ou Senado (art. 14); o Poder Moderador, chave de toda a organização política, delegado privativamente ao Imperador como chefe supremo da Nação e seu primeiro representante a velar incessantemente sobre a manutenção da independência, equilíbrio harmônico dos demais poderes políticos; o Poder Executivo, tendo por chefe o Imperador, que o exerce com os seus ministros (art. 102), e o Poder Judicial, independente e composto de juízes e jurados, os quais terão lugar, assim no cível como no criminal, nos casos e pelo modo que os códigos determinarem (art. 151). ${ }^{107}$

A refutação do anteprojeto e a adoção do modelo absolutista em decorrência da previsão do Poder Moderador - presente singularmente nessa Constituição - não foi bem aceita em todo o país, levando a revoltas como a Confederação do Equador, em Pernambuco. ${ }^{108}$ Com isso, podemos concluir que:

Apesar de não se tratar de nada original - até porque o nosso pensamento político apenas refletia o que nos vinha de fora, numa espécie de 'fatalismo intelectual' que subjuga as culturas nascentes - mesmo assim foi um grande estatuto político, uma lei fundamental que logrou absorver e superar as tensões entre o absolutismo e o liberalismo, marcantes no seu nascimento, para se constituir, afinal, no texto fundador da nacionalidade e no ponto de partida para a nossa maioridade constitucional.

(...)

Do ponto de vista dogmático-constitucional, duas particularidades devem ser destacadas nessa Carta Política: a atribuição ao próprio Poder Legislativo das prerrogativas de interpretar as leis e velar na guarda da Constituição, e a definição do que seria matéria constitucional, para os fins de alteração do seu texto. ${ }^{109}$

No plano internacional, vale registrar a necessidade do reconhecimento da independência política brasileira, uma vez que, somente assim, o Brasil poderia ser tratado como sujeito de direitos e membro da sociedade internacional. ${ }^{110}$ Assim, os primeiros a reconhecerem o Estado brasileiro foram os Estados Unidos, que possuíam interesse na expansão da Doutrina Monroe, traduzida no lema "a América para os americanos". A

\footnotetext{
${ }^{107} \operatorname{BOSON}$ (1996, p. 231-232)

${ }^{108}$ KOSHIBA; PEREIRA (2003, p. 223)

${ }^{109}$ MENDES; COELHO; BRANCO (2007, p. 153-154)

${ }^{110}$ BOSON (1996, p. 232)
} 
Inglaterra, em seguida, para manter os privilégios comerciais que aqui possuía, e com interesse em assinar novos tratados com o Brasil diante do crescimento de sua produção industrial, não só reconheceu a independência brasileira, como também convenceu Portugal a reconhecê-la por meio de uma indenização. ${ }^{111}$ Aqui nota-se claramente como o Direito Internacional serve à ordem econômica internacional, sendo meio de regulação.

O Brasil passou pelo Primeiro e Segundo Reinados, tendo entre eles um período Regencial. Com a Lei Áurea, datada de 13 de maio de 1888, responsável pela abolição da escravatura, houve a substituição dos escravos pelos imigrantes na lavouras cafeeiras. Foi uma mudança que o Império não conseguiu acompanhar, já que era uma de suas bases aristocráticas, levando à proclamação da República, mesmo sem nenhuma revolução, pois foi uma sequência natural, como uma "evolução". 112

O que nos interessa é, na verdade, a nova Constituição que foi formulada. A troca de uma Constituição de um país denota o marco formal da mudança do formato do Estado, mas, no plano internacional, apesar do interesse e relevância em analisar o conteúdo da nova Constituição, não há a necessidade de reconhecimento, como ocorre quando um país se declara independente, pois funciona como uma troca de governo. ${ }^{113}$

Logo após a proclamação, foi convocada um Assembleia Constituinte que promulgou a segunda Constituição brasileira e a primeira da República, em 24 de fevereiro de 1891. Daí em diante, o voto seria aberto, facultativo, restrito aos alfabetizados.

A nova Constituição inspirou-se no modelo norte-americano, ao contrário da Constituição imperial, inspirada no modelo francês.

De acordo com a Constituição de 1891, nosso país estava dividido em vinte estados (antigas províncias) e um Distrito Federal (ex-município neutro). Declarava também que o Brasil era uma república representativa, federalista e presidencialista. ${ }^{114}$

A maior crítica à nova Constituição era a de que ela não correspondia à realidade social brasileira. Ao adotar o modelo americano, em que existia o centripetismo, ou seja, os Estados apartados buscavam unir-se, o constituinte parece ter se esquecido de fazer as adaptações necessárias ao centrifugismo, isto é, quando o que era uma unidade deve se separar e se transformar em novos Estados. Dessa forma, apesar de grandes conquistas como a extinção do Poder Moderador, a abolição da pena de morte, a liberdade religiosa, a ampla defesa e a criação do habeas corpus, o modelo adotado, ao retirar poder da instância central e

\footnotetext{
${ }^{111}$ KOSHIBA; PEREIRA (2003, p. 229)

112 KOSHIBA; PEREIRA (2003, p. 323)

${ }^{113}$ BOSON (1996, p. 233)

${ }^{114}$ KOSHIBA; PEREIRA (2003, p. 379-380)
} 
delegá-lo às instâncias regionais, trouxe a prática do coronelismo e do voto de cabresto, por exemplo, já que o voto era aberto. ${ }^{115}$

O agravamento dessa situação e o descontentamento com a política café-comleite, além da crise mundial de 1929, que trouxe a desvalorização do café, desembocaram na Revolução de 1930. Após o golpe contra Washington Luís, formou-se um governo provisório, sob a liderança de Getúlio Vargas. ${ }^{116}$

Outubro de 1930 marcou o fim de uma República ao mesmo tempo em que fechou um capítulo de nossa história federativa e republicana. Foi 30, sem dúvida, ano de grandes comoções patrióticas, de esperanças cívicas, de confiança no futuro. O Estado liberal da versão clássica - durante mais de um século a ideia-força das nossas instituições - chegava ao fim, depois de haver atravessado dois regimes de um Império e uma República. O País acordava então para as mudanças do século. A ditadura do Governo Provisório, em algumas matérias políticas e sociais, entrava com a mesma força, o mesmo ímpeto, a mesma energia dos republicanos de 89, quando instauram a Primeira República e cuidaram de varrer, em vinte e quatro horas, por decreto-lei, todas as instituições básicas do Império. Era a aurora do Estado Social. ${ }^{117}$

O liberalismo foi desacreditado após a Primeira Guerra Mundial e, principalmente, após a crise de 1929. Percebia-se a necessidade de intervenção estatal, ganhando força, inclusive, a doutrina do comunismo, antiliberal e antidemocrática, após a Revolução de 1917 e a formação da União Soviética. Na extrema direita surgiram também alternativas como o nazismo e o fascismo. Embora o Brasil não seguisse nenhuma dessas correntes, o governo se mostrava extremamente centralizado. Aliás, após o golpe só foi instaurada a Assembleia Constituinte depois da Revolução Constitucionalista de 1932, ocorrida em São Paulo. Ainda assim, a Assembleia Constituinte transformou-se em Câmara dos Deputados, sendo a responsável pela eleição do novo presidente - o que, por óbvio, fez com que Getúlio Vargas permanecesse na presidência. ${ }^{118}$

Por outro lado, foi elaborado um Código Eleitoral que estabelecia o voto secreto e também a extensão do voto às mulheres. ${ }^{119}$ Quando a Constituição foi promulgada, em 1834, também entraram em vigor diversas medidas inovadoras e benéficas à população, quais sejam: a eleição indireta de deputados por meio da representação classista, ou seja, dos sindicatos profissionais, além da eleição direta; a instituição do salário mínimo e de diversos outros benefícios trabalhistas, proibindo-se também a diferença salarial discriminatória; a

\footnotetext{
${ }^{115}$ MENDES; COELHO; BRANCO (2007, p. 154 et seq.)

${ }^{116}$ KOSHIBA; PEREIRA (2003, p. 414 et seq.)

${ }^{117}$ BONAVIDES; ANDRADE apud MENDES; COELHO; BRANCO (2007, p. 156-157)

${ }^{118}$ KOSHIBA; PEREIRA (2003, p. 420 et seq.)

${ }^{119}$ KOSHIBA; PEREIRA (2003, p. 441)
} 
obrigatoriedade do ensino primário; a criação de institutos previdenciários e da Justiça do Trabalho, bem como a assistência judiciária gratuita aos necessitados; e a instituição do mandato de segurança. ${ }^{120}$

No plano internacional, a maior relevância se deu no tocante ao nacionalismo e à estatização, sendo impostas medidas restritivas à imigração, principalmente nipônica. Também nesse sentido, impediu a extradição de brasileiros e, em caso de crime político ou de opinião, também a de estrangeiro, criando, assim, o asilo político.

Preconizou a estatização de empresas estrangeiras e nacionais, quando fosse do interesse geral da nação. Nacionalizou as companhias de seguro estrangeiras. Estabeleceu o princípio da propriedade nacional do subsolo, explorável pela iniciativa privada mediante explícita concessão estatal. Por fim, nacionalizou a informação, proibindo a imprensa nas mãos de estrangeiros. ${ }^{121}$

Em razão do exposto, Cezar Saldanha classifica a Constituição de 1934 como a mais criativa da história brasileira. Infelizmente, ela foi também a que perdurou por menor período de tempo, pois a ela logo se seguiu o período ditatorial conhecido como Estado Novo, que traria consigo a Constituição de $1937{ }^{122}$

O golpe, em verdade, foi apenas o coroamento, triste embora, de algo que já vinha se manifestando desde o início da Segunda República, ou seja, a pouca ou nenhuma inclinação de Getúlio Vargas para as práticas democráticoinstitucionais, que ele substituíra pela lógica do individualismo providencialista, que outra coisa não significava senão uma política contraditória, autoritária, populista, imperial e caudilhista, como assinalam, entre outros, os críticos Paulo Bonavides e Paes de Andrade. ${ }^{123}$

Sob o pretexto de proteção nacional da "ameaça comunista", Vargas já havia decretado estado de sítio e, com um suposto plano de golpe chamado Plano Cohen, pediu ao Congresso que concedesse o estado de guerra. Com isso, o presidente decretou o fechamento do Congresso e outorgou a Constituição que seria conhecida como "Polaca", em decorrência de suas semelhanças em relação à Constituição da Polônia, além de inspirações nazifascistas. ${ }^{124}$ Mais uma vez percebe-se a influência da história mundial na história brasileira, o que denota a importância da cooperação internacional.

Na referida Constituição, o Executivo foi declarado como "órgão supremo do Estado" e o chefe desse poder, além de ter seu mandato estendido para seis anos, possuía total

\footnotetext{
${ }^{120}$ KOSHIBA; PEREIRA (2003, p. 442-443)

${ }^{121}$ KOSHIBA; PEREIRA (2003, p. 442)

122 SALDANHA apud MENDES; COELHO; BRANCO (2007, p. 157)

${ }^{123}$ MENDES; COELHO; BRANCO (2007, p. 159)

${ }^{124}$ KOSHIBA; PEREIRA (2003, p. 447 et seq.)
} 
controle sobre os Estados, podendo, a qualquer tempo, nomear interventores. A pena de morte foi instaurada e a censura aos meios de comunicação era tida como legal. ${ }^{125}$

Embora a Constituição previsse que o Presidente poderia editar normas "enquanto o Parlamento Nacional não se reunisse" - além de poder submeter por uma segunda vez ao Parlamento matéria que houvesse sido declarada inconstitucional pelo Tribunal e, caso novamente aprovada por um quórum determinado, a decisão do Tribunal seria ineficaz e a Constituição estaria emendada - o Parlamento não foi aberto durante o período ditatorial, o que fez com que o Presidente usurpasse suas competências, tendo em vista que ele também era parte do Poder Legislativo. Havia, assim, um "anticontrole de constitucionalidade", pois, norma nenhuma estaria sujeita a revisão diante da concentração de poderes. ${ }^{126}$

O Presidente da República, que os editara, sobrepôs o seu arbítrio à vontade objetiva da Carta Política, revelada pelo tribunal, num gesto insólito que pareceu confirmar, simultaneamente, pelo menos duas importantes teorias filosófico-políticas: a de Fernando Lassale, para quem os problemas constitucionais, basicamente, não são problemas jurídicos, mas questões de poder; e a de Hans-Georg Gadamer, que reputa incompatíveis hermenêutica jurídica e regimes de força, porque nesses governos de fato o senhor absoluto, melhor do que ninguém, sempre poderá "explicar" as suas próprias palavras e sobrepô-las às regras usuais de interpretação, de resto não vinculativas para ele. ${ }^{127}$

Muitos doutrinadores defendem que essa Carta Política nem sequer vigorou de direito, mas apenas de fato, já que não chegou a ser realizado o plebiscito que ela mesma havia previsto e que a legitimaria. Assim, com o fim da Segunda Guerra Mundial e a queda dos regimes nazifascistas, a ditadura perde os únicos pilares que a sustentavam: o medo e a força. Vargas é então destituído do poder, apesar do movimento que ficou conhecido como "queremismo", que o apoiava, e logo em seguida foi eleito senador. Não participou efetivamente da Constituinte, como não poderia deixar de ser, que concluiu a nova Constituição em $1946 .^{128}$

"Essa experiência [a partir de 1946] durou dezoito anos e foi caracterizada pelos historiadores e sociólogos como os anos áureos do populismo."129 A Era Vargas, no plano interno, e a Guerra Fria, de maneira geral, no plano internacional, trouxeram as classes populares para o cenário político.

\footnotetext{
${ }^{125}$ KOSHIBA; PEREIRA (2003, p. 450-451)

${ }^{126}$ MENDES; COELHO; BRANCO (2007, p. 159-160)

${ }^{127}$ MENDES; COELHO; BRANCO (2007, p. 160)

${ }^{128}$ MENDES; COELHO; BRANCO (2007, p. 161-162)

${ }^{129}$ KOSHIBA; PEREIRA (2003, p. 467)
} 
Além disso, consolidou-se, sobretudo na Europa, a ideia da necessidade de construir um Estado do Bem-estar Social (Welfare State), capaz de promover justiça e igualdade social, ainda que nos limites do capitalismo. Essa seria a melhor forma de conter o avanço do comunismo e viabilizar a reconstrução do continente europeu, arrasado pela guerra. ${ }^{130}$

A Constituição de 1946 teve como base a Constituição de 1934, sendo a primeira Carta Política brasileira a não adotar uma Constituição estrangeira como referência. Além das características já apresentadas na própria Carta de 1934, a nova expressão do constituinte distribuiu melhor as competências entre os entes federativos e bem demarcou os direitos políticos e também os sociais. Por outro lado, Reale aponta como seus defeitos: o enfraquecimento do Executivo em detrimento do Legislativo, sendo prevista, inclusive a formação da Comissão Parlamentar de Inquérito; os obstáculos colocados à intervenção estatal no domínio econômico, apesar da indústria brasileira incipiente; e a falta de limites ao pluripartidarismo, o que levou à criação de partidos oportunistas. ${ }^{131}$

A explicação em relação à prevalência dos Poderes Legislativo e Judiciário se deve, na verdade, a uma tentativa de compensação pelo desprestígio por que haviam passado esses poderes políticos durante o período do Estado Novo. Além disso, a doutrina explica que, embora tivesse texto muito semelhante ao de 1934, a Constituição de 1946 perdurou por muito mais tempo em decorrência de um ambiente internacional favorável, ao contrário do que havia ocorrido no Governo Vargas, ainda que com alguns abalos internos. ${ }^{132}$

\footnotetext{
Assim, numa eleição realizada de acordo com regras aceitas pelos concorrentes, é preciso que todos acatem seus resultados. A democracia também supõe alternâncias no poder, já que os perdedores de hoje poderão ser os vitoriosos de amanhã.

(...)

Assim, se é verdade que de 1946 a 1964 houve regularmente eleições para presidente, deputados, senadores e governadores, é preciso reconhecer que nem sempre foi com grande dificuldade que os perdedores aceitaram a derrota, sobretudo nas disputas para a Presidência. As pregações em favor de golpes, anulações de resultados eleitorais e ameaças de impedir a posse dos eleitos, quer por meio das armas, quer por meio de expedientes jurídicos, foram freqüentes. A democracia esteve o tempo todo sob risco. ${ }^{133}$
}

Assim, após a renúncia de Jânio Quadros, acusado de tramar para o Brasil um regime socialista como o de Cuba, os militares tentaram impedir a todo custo que João Goulart, vice-presidente, assumisse o governo, também por medo de sua ligação ao comunismo. Goulart assume, então, sob a forma do parlamentarismo, para que seu poder

\footnotetext{
${ }^{130}$ KOSHIBA; PEREIRA (2003, p. 468)

${ }^{131}$ MENDES; COELHO; BRANCO (2007, p. 163)

${ }^{132}$ MENDES; COELHO; BRANCO (2007, p. 163-164)

${ }^{133}$ KOSHIBA; PEREIRA (2003, p. 468)
} 
fosse limitado, mas, ao não conseguir implementar as mudanças previstas no Plano Trienal e nem mesmo as reformas de base que havia proposto, perdeu apoio da grande massa popular. O estopim para sua deposição foi quando Goulart se indispôs com as Forças Armadas publicamente, e já não havia mais quem o apoiasse: isso levou ao golpe militar de $1^{\mathrm{o}} \mathrm{de}$ abril de $1964 .^{134}$

A Constituição de 1946 continuou vigente, a princípio, embora com alteração do Ato Institucional número 1, pelo qual muitos artigos foram suspensos e foi prevista a eleição indireta para presidente - sendo eleito o general Castelo Branco. Inicialmente os militares pretendiam ser um "movimento democrático, constitucionalista, contrário às ameaças comunistas" ${ }^{135}$, mas a Constituição promulgada em 1967 em muito parecia com a Constituição ditatorial do Estado Novo. Podem, no entanto, ser citadas duas alterações feitas por essa nova Constituição referentes ao plano internacional que permaneceram até os dias de hoje, quais sejam: a possibilidade de celebrar tratados com as Organizações Internacionais hipótese não vislumbrada pelo constituinte de 1946 e que encontra guarida no art. 8 , I em 1967 e no art. 21, I, em $1988^{136}$ - e também a mudança do nome oficial do país de "Estados Unidos do Brasil" para "República Federativa do Brasil", como vigora atualmente. ${ }^{137}$

Junto à nova Constituição de 1937, foram editadas também a Lei de Imprensa e a Lei de Segurança Nacional, que praticamente acabavam com os limites ao poder do Presidente, prevendo, inclusive, o julgamento de crimes contra a Segurança Nacional por Tribunais Militares. ${ }^{138}$ Nesse momento, por meio de Atos Institucionais, já era possível a demissão de funcionários públicos, a cassação de direitos políticos e a extinção dos partidos políticos e demais organizações "subversivas".

No âmbito do processo legislativo, igualmente merecedora de crítica foi a prerrogativa, atribuída ao Presidente da República, para expedir decretos-leis sobre segurança nacional e finanças públicas, um faculdade tanto mais autoritária quanto vinha acompanhada da previsão de que esses textos legislativos teriam vigência imediata, não poderiam ser emendados pelos deputados e senadores e, se não fossem votados dentro de sessenta dias, a contar do seu recebimento pelo Congresso Nacional, seriam tidos como aprovados. A experiência encarregou-se de mostrar os efeitos deletérios dessa novidade, traduzidos na enxurrada de decretos-leis, que o Presidente da República editava "impunemente", com a certeza de que, para a sua aprovação definitiva, poderia contar com a velha e malfadada inércia do Poder Legislativo, de resto igualmente "operante" para a chancela dos

\footnotetext{
${ }^{134}$ KOSHIBA; PEREIRA (2003, p. 506 et seq.)

${ }^{135}$ KOSHIBA; PEREIRA (2003, p. 510)

${ }^{136}$ TRINDADE (2003, p. 183)

${ }^{137}$ BOSON (1996, p. 234)

${ }^{138}$ KOSHIBA; PEREIRA (2003, p. 532)
} 
projetos que o Executivo, nos termos do art. 54 daquela Constituição, poderia encaminhar ao Congresso Nacional para apreciação acelerada.

Mesmo assim, como esses maus exemplos costumam deixar rastros e fazer adeptos, com destaque, no particular, para os que são tentados a "normalizar" instrumentos de exceção, em razão disso, quem se dispuser a fazer a interpretação histórica - para desvendar-lhes a teleologia - dos preceitos que, atualmente, constrangem o Congresso a votar medidas provisórias e projetos de iniciativa do Presidente da República (CFB - arts. $62, \S 6^{\circ}$, e $\left.64, \S 2^{\circ}\right)$ (...) desculpam-se - são obrigados a continuar administrando para não mergulhar o País em crises de governabilidade, algo tão esotérico que nem eles sabem o que é. ${ }^{139}$

A oposição a essas medidas só crescia, o que levou os governantes a editarem o AI-5, em dezembro de 1968, e a Emenda Constitucional $\mathrm{n}^{\circ} 1$ de 1969, que alguns doutrinadores chegam a considerar como uma nova Constituição, pois, ao suprimir direitos fundamentais previstos na Constituição de 1967, modificou-se substancialmente, tentando dar caráter jurídico ao poder de fato instituído ${ }^{140}$ - suspendeu o habeas corpus, retirou da apreciação do Judiciário os atos praticados pelo Presidente, instituiu a pena de morte e estabeleceu a presunção de culpa, além da censura e da suspensão da liberdade de reunião. ${ }^{141}$

“A partir de 1974, com a ascensão do quarto general-presidente, Ernesto Geisel, a ditadura militar iniciou um processo de autodissolução controlada que só iria se completar em 1985." ${ }^{\prime 142}$, pois parte do próprio governo desejava a retomada do poder pelos civis para não desgastar ainda mais a imagem das Forças Armadas. Assim, em 1978 foi revogado o AI-5 e, no ano seguinte, foi decretada a anistia e voltou a existir o pluripartidarismo. O governo foi passado aos civis com a eleição indireta de Tancredo Neves, que morreu antes de tomar posse. Com isso, Sarney, seu vice, assumiu a presidência e constatou os novos desafios: controlar a inflação e combater a recessão econômica escondidas durante o regime militar e decorrentes da globalização financeira. ${ }^{143}$

No plano internacional, os Estados Unidos, após a derrota na Guerra do Vietnã, que desfalcou as finanças americanas, romperam unilateralmente os acordos de Bretton Woods, passando, então, o câmbio a ser flutuante, pois o dólar, moeda considerada internacional, não possuía mais lastro em relação ao ouro - houve, então, a financeirização do capitalismo, o que repercutiu na inflação e no endividamento brasileiros. Além disso, o preço do barril de petróleo foi dobrado pela Organização de Países Exportadores de Petróleo, na

\footnotetext{
${ }^{139}$ MENDES; COELHO; BRANCO (2007, p. 167-168)

${ }^{140}$ MENDES; COELHO; BRANCO (2007, p. 169)

${ }^{141}$ KOSHIBA; PEREIRA (2003, p. 517)

${ }^{142}$ KOSHIBA; PEREIRA (2003, p. 519)

${ }^{143}$ KOSHIBA; PEREIRA (2003, p. 520-521)
} 
época em que o Brasil crescia industrialmente. ${ }^{144}$ Por outro lado, a queda do muro de Berlim e o fim da União Soviética fizeram com que os Estados Unidos perdessem o interesse em manter as ditaduras latino-americanas como satélites contra a "ameaça comunista".

A ascensão científica e política do direito constitucional brasileiro é
contemporânea da reconstitucionalização do país com a Carta de 1988 , em
uma intensa relação de causa e efeito. A Assembleia Constituinte foi cenário
de ampla participação da sociedade civil, que permanecera alijada do
processo político por mais de duas décadas. O produto final de seu trabalho
foi heterogêneo. De um lado, avanços como a inclusão de uma generosa
carta de direitos, a recuperação das prerrogativas dos Poderes Legislativo e
Judiciário, a redefinição da Federação. De outro, no entanto, o texto
casuístico, prolixo, corporativo, incapaz de superar a perene superposição
entre o espaço público e o espaço privado no país. A Constituição de 1988
não é a Carta da nossa maturidade institucional, mas das nossas
circunstâncias. Não se deve, contudo, subestimar o papel que tem
desempenhado na restauração democrática brasileira. Sob sua vigência vem-
se desenrolando o mais longo período de estabilidade institucional da
história do país, com a absorção de graves crises políticas dentro do quadro
da legalidade constitucional. E a nossa primeira Constituição
verdadeiramente normativa e, a despeito da compulsão reformadora que
abala a integridade de seu texto, vem consolidando um inédito sentimento
constitucional. ${ }^{145}$

Desse modo, a Constituição de 1988, que foi apelidada de Constituição Cidadã por Ulisses Guimarães em razão de seu grande elenco de garantias individuais e direitos sociais, muitos deles decorrentes, inclusive, de traumas em relação ao período da ditadura militar, adotou a forma republicana e o sistema presidencialista de governo, apesar dos interesses conflitantes durante a Constituinte. Os congressistas eleitos para a Assembleia continuariam seus mandatos em seguida, não estando sujeitos a novas eleições. A eleição de um Congresso com poderes constituintes suscitou dúvidas em relação à manutenção do regime militar, tendo em vista o poderio desse grupo ainda durante os debates. ${ }^{146}$ A doutrina, no entanto, esclarece: "Houve, portanto, na elaboração da Constituição de 1988, a intervenção do poder constituinte originário. Instaurou-se um novo regime político, superando o anterior. Adotou-se uma nova ideia de Direito e um novo fundamento de validade da ordem jurídica. (grifo nosso)",147

"Por constituição moderna entende-se a ordenação sistemática e racional da comunidade política através de um documento escrito no qual se declaram as liberdades e os direitos e se fixam os limites do poder político." ${ }^{148}$ Não se pretende esgotar as características

\footnotetext{
${ }^{144}$ KOSHIBA; PEREIRA (2003, p. 522 et seq.)

${ }^{145}$ BARROSO (2008, p. 340-341)

${ }^{146}$ KOSHIBA; PEREIRA (2003, p. 575 et seq.)

${ }^{147}$ MENDES; COELHO; BRANCO (2007, p. 191)

${ }^{148}$ CANOTILHO (1998, p. 46)
} 
trazidas pela atual Constituição, pois além de o seu formato analítico dificultar e estender demasiadamente o estudo, não é esse o foco do presente trabalho. Buscamos abordar, no entanto, qual é o tratamento dado por esse diploma legal às normas internacionais, embora, como destaca o professor George Galindo, a Constituição, mais uma vez, tenha escolhido ser omissa no tocante à hierarquia entre Direito Internacional e Direito Interno, ou seja, qual norma deve prevalecer em caso de conflito.

A tradição de nossas Constituições foi mantida: o silêncio constitucional absoluto sobre as relações entre Direito Internacional e Direito Interno, no que concerne à inserção do primeiro no segundo.

Não se pode dizer que a possibilidade de inserção direta do Direito Internacional no Direito Interno era desconhecida - a Constituição dos Estados Unidos tratou do tema no que tange aos tratados. Em matéria de Direito Internacional Geral, Constituições da primeira metade do século, como a Constituição de Weimar, consideravam o Direito Internacional parte do Direito Interno. Inúmeros Estados europeus, inclusive os antigos socialistas mais recentemente, como já visto, consideram o Direito Internacional Geral parte do Direito Interno.

Ademais, a aplicação direta é imprescindível para o desenvolvimento de um Direito Comunitário, que não pode deixar à margem dos Estados a incorporação de seus respectivos atos.

Perdeu-se outra oportunidade de aclarar a matéria. ${ }^{149}$

Por outro lado, em seu preâmbulo a Constituição já expressa consideração em relação ao internacionalismo, como podemos perceber:

Nós, representantes do povo brasileiro, reunidos em Assembléia Nacional Constituinte para instituir um Estado Democrático, destinado a assegurar o exercício dos direitos sociais e individuais, a liberdade, a segurança, o bemestar, o desenvolvimento, a igualdade e a justiça como valores supremos de uma sociedade fraterna, pluralista e sem preconceitos, fundada na harmonia social e comprometida, na ordem interna e internacional, com a solução pacífica das controvérsias, promulgamos, sob a proteção de Deus, a seguinte Constituição da República Federativa do Brasil. ${ }^{150}$

Além disso, em seu artigo $4^{\circ}$, a referida Constituição prevê alguns dos princípios que devem conduzir as relações do país no plano internacional, quais sejam: a independência nacional, que está diretamente ligada à igualdade entre os Estados e à nãointervenção, como expressões da soberania no estrangeiro. A não-intervenção, por sua vez, juntamente com a previsão de solução pacífica dos conflitos, auxilia a defesa da paz, essencial para a cooperação entre os povos para o progresso da humanidade. A melhor expressão desse progresso se encontra na prevalência dos direitos humanos, de que o repúdio ao terrorismo e

${ }^{149}$ GALINDO (2001, p. 127)

${ }^{150}$ CONSTITUIÇÃO FEDERAL (BRASIL, 1988) 
ao racismo faz parte, além do respeito à autodeterminação dos povos, sendo a concessão de asilo político uma forma de exprimir esse respeito. ${ }^{151}$

O parágrafo desse mesmo artigo traz a previsão da busca pela integração econômica, política, social e cultural entre os povos da América Latina, mas, em um mundo globalizado como o que temos atualmente, devemos entender que essa cooperação se faz necessária não apenas em âmbito latino-americano, mas sim, global. Esse seria o ideal, segundo o projeto de Habermas, comentado por Häberle:

Sólo una ciudadanía democrática que no se cierre en términos particularistas puede, por lo demás, preparar el camino para un status de ciudadano del mundo o una cosmociudadanía, que hoy empieza ya a cobrar forma en las comunicaciones políticas que tienen un alcance mundial. El Estado cosmopolita ya ha dejado de ser un simple fantasma, aun cuando nos encontremos todavía bien lejos de él. El ser ciudadano de un Estado y el ser ciudadano del mundo constituyen un continuum cuyos perfiles empiezan ya al menos a dibujarse. ${ }^{152}$

O Brasil assegura, ainda, os mesmos direitos aos brasileiros e aos estrangeiros que aqui estejam, conforme previsto no art. $5^{\circ}$. É esse mesmo artigo que restringe a extradição de estrangeiro por crime político ou de opinião, como não poderia deixar de ser, tendo em vista a concessão de asilo político ser um dos princípios regentes das relações internacionais brasileiras. No mesmo dispositivo se encontra, ainda, a previsão de que, aberta a sucessão, com o falecimento de estrangeiro, será aplicada a lei brasileira aos bens deixados em território nacional, a menos que a lei do país do de cujus seja mais favorável a seus herdeiros. $\mathrm{O}$ disposto nos parágrafos do art. $5^{\circ}$ que se refere ao Direito Internacional será abordado mais adiante. $^{153}$

No tocante aos tratados e demais acordos internacionais, a Constituição prevê como competência exclusiva do Congresso Nacional resolvê-los (art. 49) e competência privativa do Presidente, celebrá-los (art. 84) - além de manter relações com Estados estrangeiros. ${ }^{154}$ Ao Supremo Tribunal Federal compete julgar ordinariamente o litígio entre Estado estrangeiro ou organismo internacional e qualquer ente federado e também, em sede de recurso extraordinário, julgar a inconstitucionalidade do tratado, o qual é, nesse momento,

${ }^{151}$ CONSTITUIÇÃO FEDERAL (BRASIL, 1988)

${ }^{152}$ HABERMAS apud HÄBERLE (2003, p. 180)

${ }^{153}$ CONSTITUIÇÃO FEDERAL (BRASIL, 1988)

${ }^{154}$ CONSTITUIÇÃO FEDERAL (BRASIL, 1988). Interessante notar que não há previsão de delegação desses poderes do Presidente, o que quer dizer que outro poder, como o Legislativo, não pode exercer essa função. No Direito Internacional, no entanto, é permitida a instituição de plenipotenciários que substituam o chefe de Estado. Além disso, os Chefes de Missões Diplomáticas e o Ministério das Relações Exteriores, que tem como função, inclusive, negociar e celebrar tratados e acordos internacionais, não estão obrigados a serem plenipotenciários no momento em que negociam ou celebram o tratado - é uma exceção ratione personae. (GALINDO, 2001, p. 109) 
equiparado a lei federal. À Suprema Corte compete também o julgamento de extradição solicitada por Estado estrangeiro. ${ }^{155}$

Cabe à União, conforme previsto no art. 22, legislar sobre emigração e imigração, entrada, extradição e expulsão de estrangeiros. Aos juízes federais cabe julgar as causas fundadas em tratado ou contrato da União, de Município ou de pessoa domiciliada ou residente no Brasil com Estado estrangeiro ou organismo internacional ou, ainda, as causas referentes à nacionalidade e à naturalização, além dos crimes previstos em tratados ou convenções ou os de ingresso ou permanência irregular de estrangeiro, bem como a execução de carta rogatória, após o exequatur, e de sentença estrangeira, após a homologação. Ao STJ, por sua vez, compete processar e julgar, em sede de recurso especial, as decisões que contrariem tratados internacionais e, ordinariamente, homologar sentenças estrangeiras e a conceder exequatur às cartas rogatórias. ${ }^{156}$

Além dessas, há diversas outras formas de interação entre os Estados, sendo, talvez, a principal delas, os tratados. Assim, vale a pena saber quais são os processos por que passam para serem celebrados, podendo ser solene e completo ou simples e abreviado. No primeiro procedimento, os atos são dispostos da seguinte maneira: negociação; assinatura; mensagem ao Congresso; aprovação parlamentar; ratificação; e promulgação. Se não houver negociação, isto é, o Estado decidir apenas aderir a um tratado que já se encontra pronto, o trâmite inicia com a mensagem ao Congresso e a ratificação é chamada de adesão, no restante sendo idêntico. O processo simples acompanha a seqüência: negociação; assinatura ou troca de notas; e publicação. ${ }^{157}$

Rezek, por sua vez, alerta que não se deve confundir o critério adotado para a classificação do processo - não é um critério temporal ou estatístico, mas sim, procedimental. Vejamos:

Aqui distinguiremos os tratados segundo o procedimento adotado para sua conclusão. Mais que a medida cronológica desse processo - um dado falacioso -, interessa-nos a questão de saber se, dentro dele, é possível detectar duas fases de expressão do consentimento das partes, este entendido como prenunciativo na primeira, a da assinatura, e como definitivo na segunda, a da ratificação, ou se, num quadro unifásico, o consentimento definitivo se exprime na assinatura, desde logo criadas as condições para a vigência do tratado. ${ }^{158}$

Exemplifica, ainda, o mestre:

\footnotetext{
${ }^{155}$ CONSTITUIÇÃO FEDERAL (BRASIL, 1988)

${ }^{156}$ CONSTITUIÇÃO FEDERAL (BRASIL, 1988)

${ }^{157}$ GALINDO (2001, p. 108)

${ }^{158}$ REZEK (2008a, p. 25-26)
} 
Um tratado em forma simples, concluído e posto em imediato vigor pela assinatura das partes no instrumento único, ou por troca de notas, não se confundirá com um acordo executivo se os governos pactuantes estiverem agindo com apoio em aprovação parlamentar tópica, expressa pelo Legislativo ao tempo mesmo da negociação ou antes. Ao reverso, é desenganadamente executivo o tratado solene, de procedimento longo, em que o intervalo entre a assinatura e a ratificação de cada parte se vê preencher não com a consulta ao respectivo parlamento - acaso desnecessária, segundo seu sistema constitucional -, mas com estudos e reflexões confinados no puro âmbito governamental. ${ }^{159}$

No Congresso Nacional, a apreciação do tratado cabe primeiramente a Câmara Legislativa, que, segundo seu Regimento Interno, analisará a constitucionalidade do tratado em suas Comissões e aprovará em seu Plenário o Decreto Legislativo que será encaminhado ao Senado. Também nesse órgão o Decreto deve ser aprovado segundo seu Regimento e promulgado pelo presidente da Casa, seguindo então para a publicação. Deve-se lembrar que será publicado, nesse momento, apenas o Decreto Legislativo, que conclui pela aprovação do tratado. A validade do tratado está sujeita, ainda, à ratificação e promulgação posteriores, realizadas pelo Presidente da República, e em seguida publicadas no Decreto do Executivo. ${ }^{160}$

Em razão de todo esse trâmite legislativo, o qual, por diversas vezes, acaba por exigir por parte do Executivo um desgaste político para a aprovação do tratado pelo Congresso, devido à sua competência exclusiva para tanto, sugere-se que, na delegação nacional responsável pela fase de negociação do tratado, a qual tem como chefe o plenipotenciário que o assinará, estejam presentes membros representantes do Parlamento, para facilitar sua posterior aprovação. ${ }^{161}$

A ratificação é um ato discricionário do Executivo. ${ }^{162}$ No entanto, a nãoratificação, o não envio à mensagem ao Congresso ou até mesmo a não assinatura de um acordo que o Estado havia negociado, parece ofender a boa-fé e a segurança jurídica, usandose para tanto de formalismos a fim de evitar o cumprimento dos acordos, pois, alguns tratados multilaterais, inclusive, apenas entram em vigor quando há um determinado número de ratificações e depósitos - forma pela qual se dá a comunicação aos demais signatários de que

\footnotetext{
${ }^{159}$ REZEK (2008a, p. 26-27)

160 GALINDO (2001, p. 110-111) O procedimento adotado para a aprovação dos tratados cuja temática seja referente aos direitos humanos é diferenciada inclusive pelo quórum, de acordo com o $\S 3^{\circ}$ do artigo $5^{\circ}$ da Constituição Federal, que o elevaram ao status de Emenda Constitucional. Alguns autores entendem que, por isso, eles também teriam eficácia imediata, independente da promulgação pelo Presidente da República. No entanto, esse assunto será abordado com maior profundidade em capítulo específico.

${ }^{161}$ REZEK (2008a, p. 37)

162 GALINDO (2001, p. 111)
} 
o país ratificou o instrumento. ${ }^{163}$ "Rousseau pondera que, lícita embora, a recusa de ratificação se pode às vezes entender como politicamente inoportuna ou inamistosa."

A assinatura é algo a cujo respeito os governos contemporâneos têm hesitado mais do que seria razoável, à vista de que esse ato apenas contribui para garantir a autenticidade do texto que se acabou de negociar no foro multilateral. A não-assinatura por parte do Estado que integrou os trabalhos negociais é um gesto sem significado jurídico, e pretende ter, no plano político, efeito publicitário da insatisfação daquele com o texto acabado, e, pois, de sua dúvida sobre a utilidade de assinar o que provavelmente não será ratificado. ${ }^{165}$

Assim, parte da doutrina entende que os tratados multilaterais obrigam os

Estados que participaram de sua negociação, independente de sua ratificação. "O comprometimento se perfez, e o tratado tem condições de vigência imediata." ${ }^{166}$ Cai por terra, assim, a classificação dos tratados segundo a natureza de suas normas, a qual dispunha que um tratado poderia ter natureza contratual ou normativa. Nesse sentido:

A crítica de Hans Kelsen a essa distinção classificatória é fulminante. Parece-lhe que tanto no tratado chamado contratual quanto naquele dito normativo, a vontade convencional das partes tem sempre um mesmíssimo objeto, constituído pela integralidade do teor do tratado. (...) Assim, Kelsen aponta como pleonasmo a expressão tratados normativos. Todos o são, dos mais transcendentes pactos universais às avenças de comércio que os Estados concluem aos pares. (...) Quando menos, o tratado contratual terá seu texto arrematado pelas indispensáveis cláusulas finais - sobre ratificação, entrada em vigor, perspectiva de denúncia -, cujo caráter normativo os autores dessa proposição classificatória não poderiam negar. ${ }^{167}$

Cabe lembrar, assim, que a ratificação é o ato de governo, e não ato internacional, pelo qual o Executivo confirma seu consentimento em se obrigar por meio daquele acordo. Sua origem histórica advém da necessidade em controlar aquilo que os plenipotenciários haviam negociado. Assim, dispõe Rezek:

Seria demasiada e temerária confiança, entretanto, permitir que o negociador plenipotenciário, numa época de comunicações lentas e difíceis, ajustasse lá fora os termos do compromisso - às vezes sob o peso de circunstâncias fortuitas e questões imprevisíveis, surgidas no curso do trabalho negocial -, e desde logo o assumisse em definitivo, trazendo ao soberano o fato consumado. $\mathrm{O}$ intervalo entre a assinatura e a ratificação era tempo de meditar sobre a qualidade do desempenho negocial do plenipotenciário, e sobre a conveniência de confirmar o pacto. ${ }^{168}$

\footnotetext{
163 GALINDO (2001, p. 112)

${ }^{164}$ REZEK (2008a, p. 52)

${ }^{165}$ REZEK (2008a, p. 44)

${ }^{166}$ REZEK (2008a, p. 46)

${ }^{167}$ REZEK (2008a, p. 29)

${ }^{168}$ REZEK (2008a, p. 51)
} 
Dessa forma, o chefe do Executivo pode, ainda, no momento da assinatura ou da ratificação, declarar unilateralmente, como qualitativo de consentimento, reserva em relação a algum de seus dispositivos, desde que isso não altere a essência da natureza do tratado. Os demais Estados signatários podem a ela se opor, todavia. Além disso, não faria sentido falar em reserva em um tratado bilateral, tendo em vista que a cláusula reservada não teria aplicação prática a nenhum sujeito, não devendo, portanto, existir. ${ }^{169}$

No caso de tratados bilaterais, normalmente desenrolados no território de um dos países pactuantes, se os Estados possuírem algum idioma em comum, não há problema, mas, caso não haja, deve ser estabelecido um idioma neutro desde as negociações - e o tratado, então, será lavrado nessa língua, em versão única, ou, se lavrado em mais de uma versão, para atender a diversos idiomas, deve ter uma versão como privilegiada para hipótese de interpretação. ${ }^{170}$

Para Strenger (2003), são contratos internacionais do comércio, todas as manifestações bi ou plurilaterais das partes, objetivando relações patrimoniais ou de serviços, cujos elementos sejam vinculantes de dois ou mais sistemas jurídicos extraterritoriais, pela força do domicílio, nacionalidade, sede principal dos negócios, lugar do contrato, lugar da execução, ou qualquer circunstância que exprima um liame indicativo de Direito aplicável. Garcez (1994) enfatiza que os contratos internacionais se particularizam por se submeterem a diferenciados e especializados mecanismos de construção, execução, interpretação e solução de conflitos.

Desta forma, o que caracteriza o contrato internacional é a presença de um elemento de estraneidade que o ligue a dois ou mais ordenamentos jurídicos nacionais (ARAÚJO, 2004). ${ }^{171}$

Assim, concluímos que os tratados internacionais possuem características e definições diferentes entre si a depender da matéria que disciplinam. Todos eles terão, no entanto, um cerne comum que tentamos demonstrar aqui, como o são, de fato, as peculiaridades em relação à solução de conflitos no plano internacional.

\subsection{A RELAÇÃO ENTRE OS PODERES DA REPÚBLICA E SUAS LEGITIMIDADES PARA ADOTAR MUDANÇAS}

Diante do exposto no tópico anterior, resta nítida a importância de uma boa e equilibrada relação entre os poderes políticos de um país para a dinamicidade na aplicação e

\footnotetext{
${ }^{169}$ REZEK (2008a, p. 66-67)

${ }^{170}$ REZEK (2008a, p. 39-40)

${ }^{171}$ VENTURA (2010, p. 94-95)
} 
no cumprimento do Direito Internacional. Não apenas no que se refere ao Legislativo e ao Executivo, mas também no tocante ao Judiciário, pois, conforme demonstra George Galindo, além dos fatores ideológico e histórico, também os fatores político e jurídico são essenciais para a questão da inserção dos tratados no Direito Interno. ${ }^{172}$

Assim, a posição dos tribunais ao adotarem as normas de Direito Internacional como verdadeiras fontes de direito ou não é determinante para saber a aplicabilidade que os tratados celebrados por um Estado terão em âmbito nacional. Assim:

Os Tribunais devem, queiram ou não e independentemente da existência ou não-existência de uma motivação em termos de política jurídica, interpretar, construir e, se for o caso, "distinguir" os casos (como se diz no Common Law), para que possam formular novas regras de decisão e testá-las quanto à sua consistência frente ao Direito vigente. Assim surge por intermédio da atividade sentenciadora dos Tribunais um Direito judicial (...), que, no decorrer da sua reutilização constante, é, em parte, condensado, isto é, formulado com vistas ao reconhecimento (...) e, em parte, confirmado, isto é, visto como aproveitável também em outros casos (...). Parece ser universalmente reconhecido hoje que essa espécie de desenvolvimento do Direito não pode ser antecipada, nem produzida, nem impedida pelo legislador. (...) Por essa razão, podemos compreender essa norma fundamental da atividade dos Tribunais (...) como o paradoxo da transformação da coerção em liberdade. Quem se vê coagido à decisão e, adicionalmente, à fundamentação de decisões, deve reivindicar para tal fim uma liberdade imprescindível de construção do Direito. Somente por isso não existem "lacunas no Direito". Somente por isso a função interpretativa não pode ser separada da função judicativa. E somente por isso o sistema jurídico pode reivindicar a competência universal para todos os problemas formulados no esquema "Direito ou não-Direito". ${ }^{173}$

Não se deve, com isso, entender que os tribunais possuam poder maior do que os demais por serem aqueles que aplicam as normas ao caso concreto, ou, nas palavras do expresidente americano Theodore Roosevelt, "representam a voz final da autoridade". ${ }^{174} \mathrm{De}$ fato, a nova Constituição trouxe garantias que antes os membros do Judiciário não detinham. Todavia, isso se deve ao fato de a nova Constituição ter assegurado maiores poderes a todos os segmentos da sociedade que haviam sido rechaçados durante a ditadura militar, não apenas ao Judiciário. Além disso, os direitos não são previstos pessoalmente aos magistrados, mas sim, institucionalmente, para que os órgãos tenham liberdade para decidir de maneira imparcial e justa, sem risco de retaliações sequer financeiras. Assim:

A Constituição de 1988 confiou ao Judiciário papel até então não outorgado por nenhuma outra Constituição. Conferiu-se autonomia institucional, desconhecida na história de nosso modelo constitucional e que se revela, igualmente, singular ou digna de destaque também no plano do direito

\footnotetext{
172 GALINDO (2001, p. 129)

${ }^{173}$ LUHMANN (1990, p. 162-163)

${ }^{174}$ ROOSEVELT apud COELHO (2010)
} 
comparado. Buscou-se garantir a autonomia administrativa e financeira do Poder Judiciário. Assegurou-se a autonomia funcional dos magistrados. ${ }^{175}$

Ao mesmo tempo, são colocadas limitações ao Poder dado ao magistrado inerentes ao Estado de direito, como o devido processo legal e a necessidade de fundamentação de suas decisões. Desde a Magna Carta, esse método é utilizado para evitar a discricionariedade do Poder Público, assim como abusos ao julgar e punir os cidadãos, afetando direitos fundamentais dentre os quais se podem citar a liberdade e a propriedade. ${ }^{176}$ Nas palavras de Montesquieu, "os juízes da nação não são, conforme já dissemos, mais que a boca que pronuncia as palavras da lei, seres inanimados que desta lei não podem moderar nem a força e nem o rigor." 177 Ainda nesse sentido, complementa Tomás de Aquino:

É melhor que todas as coisas sejam reguladas por lei do que deixar que sejam decididas por juízes; e isto por três razões. Primeiro, porque é mais fácil encontrar alguns sábios competentes para conceber leis justas do que encontrar os muitos que seriam necessários para julgar corretamente cada caso particular. - Segundo, porque aqueles que fazem leis consideram durante muito tempo quais as leis que devem ser feitas; ao passo que o julgamento de cada caso particular deve ser pronunciado tão logo ele surja; e é mais fácil para o homem ver o que é certo levando em consideração muitos exemplos do que considerando um fato isolado. - Terceiro, porque os legisladores julgam no abstrato e sobre fatos futuros; ao passo que aqueles que participam de julgamentos julgam coisas presentes, em relação às quais estão afetados pelo amor, pelo ódio ou por algum tipo de cobiça; por esse motivo, seu julgamento é pervertido. ${ }^{178}$

Por outro lado, parte da doutrina reconhece a importância do Judiciário, considerando que todo texto está sujeito a interpretação e essa, quando mal realizada, leva à desgraça da lei, bem como de quem ela serve. "Não existe norma jurídica, senão norma jurídica interpretada. Interpretar um ato normativo nada mais é do que colocá-lo no tempo ou integrá-lo na realidade pública." 179

Por vezes, a própria lei adota esse entendimento, como, por exemplo, no artigo 557 do Código de Processo Civil, que dispõe acerca do não seguimento a recurso em confronto com súmula ou com jurisprudência dominante do respectivo tribunal, do Supremo

\footnotetext{
${ }^{175}$ MENDES; COELHO; BRANCO (2007, p. 883)

${ }^{176}$ CANOTILHO (1998, p. 87-88)

177 MONTESQUIEU (2007, p. 172) A nosso ver, essa postura deve ser combatida para que não se cometam injustiças, pois, quando a parte recorre ao Judiciário com uma demanda, pode-se perceber o descumprimento da lei e a inconformidade do cidadão, que procura o Estado para lhe defender já que esse tomou para si o monopólio do uso da força. Cometer injustiças em razão da aplicação irracional da lei seria incentivar a autotutela, o que não interessa ao Estado.

${ }^{178}$ AQUINO apud MORRIS (2002, p. 64-65)

${ }^{179}$ HÄBERLE apud VALE; MENDES (2009)
} 
Tribunal Federal, ou de Tribunal Superior - ou seja, referido artigo dá, à jurisprudência consolidada, força de lei. ${ }^{180}$

Em razão disso, alguns dizem que o Judiciário nacional vem padecendo de ativismo judicial, que seria, segundo Elival Ramos, "o exercício da função jurisdicional para além dos limites impostos pelo próprio ordenamento jurídico", pois esses o limitariam a julgar conflitos de interesses e conflitos normativos. ${ }^{181}$ Assim, seria como se o Poder Judiciário usurpasse as funções atribuídas aos demais Poderes, indo além daquilo que poderia.

Diversamente do ativismo judicial, que desrespeitaria esses limites [limites normativos substanciais no sistema de separação de poderes do Estado Constitucional de Direito], a criação judicial do Direito seria o exercício regular do poder-dever, que incumbe aos juízes, de transformar o direito legislado em direito interpretado/aplicado, caminhando do geral e abstrato da lei ao singular e concreto da prestação jurisdicional, a fim de realizar a justiça em sentido material, que nisto consiste o dar a cada um o que é seu. ${ }^{182}$

Até mesmo porque, como bem se sabe, o magistrado não pode deixar de decidir a causa sob a alegação de que não há norma que se aplique àquele caso concreto e, inevitavelmente, isso ocorrerá, pois, por mais que o legislador exerça sua criatividade, é impossível prever todas as situações do cotidiano - utiliza-se, inclusive, nesses casos, os princípios de direito, ainda que não expressamente previstos em lei. ${ }^{183}$

Não se pode negar a justiça aos cidadãos em razão de uma interpretação literal da lei, mas devemos lembrar que essa é apenas uma das expressões do Direito, que consiste em algo muito mais amplo. Por óbvio, seria um retrocesso abrir mão de tudo o que foi conquistado desde a época das Revoluções Liberais, mas, por outro lado, para alcançar o desenvolvimento pleno do Estado Social, deve-se buscar o equilíbrio entre o que seria chamado de ativismo judicial e a rigidez da separação clássica entre os Poderes. ${ }^{184}$

A liberdade do intérprete/aplicador do direito, por outro lado, há de ser uma liberdade responsável e auto-controlada, pois não lhe é dado introduzir na lei o que deseja extrair dela e tampouco aproveitar-se da abertura semântica dos textos para neles inserir, fraudulentamente, conteúdos que, de antemão, ele sabe serem incompatíveis com esses enunciados normativos.(...)

Nesse sentido é o ensinamento de Gadamer, a nos dizer que uma consciência formada hermeneuticamente tem que se mostrar receptiva, desde o começo, à alteridade do texto, sem que isso signifique neutralidade ou autodestruição diante dele; que uma verdadeira compreensão exige confronto/interação entre as verdades do intérprete e as verdades do texto; e que, enfim, uma coisa é respeitarmos a alteridade/transcendência do texto e outra, bem diversa, é adotarmos uma postura de "objetividade eunuca", que a tanto

\footnotetext{
${ }^{180}$ COELHO (2010)

${ }^{181}$ RAMOS apud COELHO (2010)

182 COELHO (2010)

183 SAVIGNY apud MORRIS (2002, p. 291-292)

${ }^{184}$ COELHO (2010)
} 
equivale nos postarmos, passivamente, diante dele sem lhe provocar com alguma pergunta. ${ }^{185}$

Assim, não se pretende negar o princípio defendido por Montesquieu, mas apenas reinterpretá-lo de modo a assegurar a melhor aplicação dele à nossa realidade. Afinal, o Brasil, ao longo de sua história, já errou por diversas vezes ao não adaptar os institutos à cultura local que importa de outros países. Como dispõe brilhantemente Inocêncio Coelho:

Portanto, e noutras palavras, o de que se trata é de re-interpretar esse velho dogma para adaptá-lo ao moderno Estado constitucional, que sem deixar de ser liberal, tornou-se igualmente social e democrático, e isso não apenas pela ação legislativa dos Parlamentos, ou pelo intervencionismo igualitarista do Poder Executivo, mas também pela atuação política do Poder Judiciário, sobretudo das modernas Cortes Constitucionais, crescentemente comprometidas com o alargamento da cidadania e a realização dos direitos fundamentais. ${ }^{186}$

O princípio da união harmônica entre os Poderes da União se encontra consubstanciado a título de cláusula pétrea no artigo $2^{\circ}$ de nossa Carta Magna, o que quer dizer que, embora independentes, os Poderes devem atuar de maneira cooperativa entre si isto é, além de exercer a função fiscalizadora do sistema de freios e contrapesos, um Poder deve auxiliar os demais a alcançar o seu melhor, flexibilizando, assim, a separação rígida, desde que não ofendida a Constituição. ${ }^{187}$

As competências atribuídas a cada um dos poderes - ainda que não sigam a rigidez da tripartição clássica, criada no momento histórico de excessos do absolutismo delimitam sua atuação, evitando abusos e atendendo aos ensinamentos de Montesquieu, que categoricamente afirma: "Tudo então estaria perdido se o mesmo homem, ou o mesmo corpo dos principais, ou o dos nobres, ou o do povo, exercesse estes três poderes: o de criar as leis, o de executar as resoluções públicas e o de julgar os crimes e as querelas dos particulares."188

Assim, é essencial ao bom funcionamento do Estado Democrático de Direito a distinção entre legislação e jurisdição, pois esse é um dos fundamentos contra a centralização do poder, além de "um instrumento de autodisciplina do sistema jurídico"189. Nesse sentido:

Mas a função da distinção entre legislação e jurisprudência não se localiza no plano organizacional; ela se localiza no sistema jurídico da sociedade. Assim o paradoxo da unidade do que é distinguido se dissolve: do ponto de vista organizacional $\mathrm{o}$ fato da distinção vale como pressuposto da

\footnotetext{
${ }^{185}$ COELHO (2010)

${ }^{186}$ COELHO (2010)

${ }^{187}$ MENDES; COELHO; BRANCO (2007, p. 146)

${ }^{188}$ MONTESQUIEU (2007, p. 166)

${ }^{189}$ LUHMANN (1990, p. 149)
} 
especificação de tarefas. Do ponto de vista social a distinção vale como unidade, como forma. ${ }^{190}$

Dessa forma, analisaremos o produto principal do processo legislativo, qual seja, a lei. Segundo Tomás de Aquino, filósofo expoente da Escolástica, a lei seria a regra e a medida dos atos de um homem, estando diretamente ligada à razão, o que possibilitaria qualquer um a criar leis, embora elas nem sempre levassem ao bem comum, pois poderiam estar dirigidas ao bem privado. Ele declara, ainda, com base em Agostinho, que "aquilo que não é justo não parece ser lei; portanto, a força de uma lei depende da extensão de sua justiça"191.

Thomas Hobbes, teórico iluminista ligado ao despotismo esclarecido, enxerga a possibilidade de legislar de outra maneira, delegando essa função apenas ao soberano, que, na visão dele, deveria controlar o estado de guerra animalesco e natural do homem. Por essa razão, o soberano estaria isento do cumprimento das leis e até mesmo as normas costumeiras seriam fruto de sua vontade, tendo em vista que apenas se encontram em vigor em razão da omissão do soberano. Ao menos a visão de Hobbes traz consigo o legalismo segundo o qual as pessoas são obrigadas apenas em virtude de lei, oferecendo um direito de primeira geração. Assim, dispõe:

Leis são regras do justo e do injusto, não sendo reputado injusto aquilo que não é contrário a alguma lei. Do mesmo modo, ninguém pode fazer leis a não ser o Estado, pois nossa sujeição é apenas para com o Estado; e as ordens devem ser expressadas por sinais suficientes; porque, caso contrário, um homem não saberia como obedecer-lhes. (...) Mais ainda, o fim da elaboração de leis não é outro senão essa restrição, sem a qual não é possível haver paz. E a lei só foi trazida ao mundo com o intuito de limitar a liberdade natural dos indivíduos, de tal maneira que eles não possam causar dano uns aos outros, mas sim se ajudarem e se unirem contra o inimigo comum. ${ }^{192}$

Grócio, a partir de sua perspectiva internacionalista, não se aprofunda no tema, mas o interpreta da seguinte maneira:

(...) outra frase de Horácio: "Foi o medo do erro que nos fez fazer nossas leis", opinião essa que um dos interlocutores da República de Platão explica dessa maneira: as leis foram introduzidas pelo medo de se receber o mal, e que os homens são impelidos a praticar a justiça por uma certa compulsão... muitos, individualmente fracos, receando ser oprimidos por aqueles que eram mais fortes, combinaram estabelecer autoridades judiciais, e apoiá-las com sua força comum; a fim de que, unidos, pudessem controlar aqueles aos quais não poderiam resistir isoladamente. ${ }^{193}$

\footnotetext{
${ }^{190}$ LUHMANN (1990, p. 155)

${ }^{191}$ AQUINO apud MORRIS (2002, p. 65)

192 HOBBES apud MORRIS (2002, p. 120-121)

${ }^{193}$ GRÓCIO apud MORRIS (2002, p. 78)
} 
Savigny chega a retirar do legislador a função legislativa, ao caracterizá-la como um procedimento de tendência popular capaz inclusive de identificar determinada população, a dizer:

Toda lei é formada originalmente à maneira pela qual, numa linguagem usual, porém não correta de todo, se diz que foi formado o direito consuetudinário; isto é, que primeiro desenvolveu-se por costume e crença popular, em seguida pela jurisprudência - em toda parte, portanto, por poderes internos que operam em silêncio, não pela vontade arbitrária de um legislador. ${ }^{194}$

Kant reitera essa tese, alegando que a união de todos para a formação das leis faz com que elas se tornem justas. O referido autor caracteriza, ainda, os cidadãos a partir de três atributos: a liberdade, pela qual ninguém está obrigado a nada, a não ser por lei; a igualdade entre os indivíduos, pois ninguém está submetido a outrem; e a independência, que atesta que a condição de cidadão advém dos direitos e poderes de um membro da sociedade.

O Poder Legislativo, visto em seu princípio racional, só caberá à Vontade unida do Povo. Pois como todo Direito deve proceder desse Poder, é necessário que suas Leis sejam incapazes de prejudicar quem quer que seja. (...) Por isso é apenas a Vontade unida e concorde de todo o Povo - na medida em que Cada qual determina a mesma coisa sobre todos, e Todos determinam a mesma coisa sobre cada um - que deve ter o poder de aprovar Lei no Estado. ${ }^{195}$

Nossa Constituição parece ter adotado essa teoria ao trazer já no parágrafo único do seu primeiro artigo a fórmula "Todo o poder emana do povo, que o exerce por meio de representantes eleitos ou diretamente, nos termos desta Constituição."196 Montesquieu, ao criar a ideia da tripartição dos poderes também previu o exercício da democracia representativa no processo legislativo.

Uma vez que, em um Estado livre, todo homem que supõe possuir uma alma livre deve ser governado por si próprio, é necessário que o povo, em seu conjunto, exerça o poder legislativo; mas como isso é impossível nos grandes Estados, e nos Estados pequenos estaria sujeito a muitos inconvenientes, é preciso que o povo exerça pelos seus representantes tudo o que não pode exercer por si mesmo. ${ }^{197}$

Dessa forma, concluímos que, ainda que o Poder Político seja exercido efetivamente por outros agentes, é o povo que legitima essa atuação, desde a criação do Estado Constitucional Democrático - produto de uma evolução histórica iniciada com a Revolução Francesa. Sendo assim, o povo, se consciente do poder que tem, deve reivindicar

\footnotetext{
${ }^{194}$ SAVIGNY apud MORRIS (2002, p. 290)

${ }^{195}$ KANT apud MORRIS (2002, p. 252)

${ }^{196}$ CONSTITUIÇÃO FEDERAL (BRASIL, 1988)

${ }^{197}$ MONTESQUIEU (2007, p. 168)
} 
que seus mandatários ajam de acordo com sua vontade. "Se o poder constituinte é a expressão da vontade política da nação, não pode ser entendido sem a referência aos valores éticos, religiosos, culturais que informam essa mesma nação e que motivam as suas ações."198

O elemento democrático não foi apenas introduzido para "travar" o poder (to check the power); foi também reclamado pela necessidade de legitimação do mesmo poder (to legitimize State power). Se quisermos um Estado constitucional assente em fundamentos não metafísicos, temos de distinguir claramente duas coisas: (1) uma é a da legitimidade do direito, dos direitos fundamentais e do processo de legislação no sistema jurídico; (2) outra é a da legitimidade de uma ordem de domínio e da legitimação do exercício do poder político. O Estado "impolítico" do Estado de direito não dá resposta a este último problema: donde vem o poder. Só o princípio da soberania popular segundo o qual "todo o poder vem do povo" assegura e garante o direito à igual participação na formação democrática da vontade popular. Assim, o princípio da soberania popular concretizado segundo procedimentos juridicamente regulados serve de "charneira" entre o "Estado de direito" e o "Estado democrático" possibilitando a compreensão da moderna fórmula Estado de direito democrático. ${ }^{199}$

Ao tratarmos a lei como produto do exercício do Poder Legislativo, tratamos também da própria Constituição, segundo o método hermenêutico-clássico de interpretação ${ }^{200}$, ainda que, ela, de fato, seja, na verdade, quem delimita os poderes políticos, sendo "estrutura política conformadora do Estado"201. "Nesse sentido se compreende a expressão constituição da República - para exprimir a ideia de que a constituição se refere não apenas ao Estado mas à própria comunidade política, ou seja, à res publica"202.

Não se pretende, contudo, ao tratar a Constituição como elemento normativo do Estado Constitucional, negar a sua posição hierárquica superior às demais normas. Embora exista o princípio da presunção de constitucionalidade das leis e atos do Poder Público, até mesmo em decorrência de toda a burocracia necessária à aprovação de uma norma, o princípio da supremacia da Constituição abarca o controle de constitucionalidade. Aliás, a sistemática da ordem jurídica exige que sejam aplicados conjuntamente os princípios da unidade da Constituição, da sua supremacia, da presunção de constitucionalidade e da interpretação conforme. $^{203}$

A conseqüência lógica do entendimento da constituição como higher law é ainda a elevação da lei constitucional a paramount law, isto é, uma lei superior que torna nula (void) qualquer "lei" de nível inferior, incluindo as leis ordinárias do legislador, se estas infringirem os preceitos constitucionais.

\footnotetext{
${ }^{198}$ MENDES; COELHO; BRANCO (2007, p. 189)

${ }^{199}$ CANOTILHO (1998, p. 93-94)

${ }^{200}$ MENDES; COELHO; BRANCO (2007, p. 93)

${ }^{201}$ CANOTILHO (1998, p. 81)

${ }^{202}$ CANOTILHO (1998, p. 82)

${ }^{203}$ BARROSO (2008, p. 370 et seq.)
} 
Diferentemente do que sucedeu no constitucionalismo inglês e no constitucionalismo francês, o conceito de "lei proeminente" (constituição) justificará a elevação do poder judicial a verdadeiro defensor da constituição e guardião dos direitos e liberdades. Através da fiscalização da constitucionalidade (judicial review) feita pelo juiz transpunha-se definitivamente o paradoxo formulado por John Locke em 1689: (...) (entre o legislador e o povo ninguém na terra é juiz). O povo americano deu a resposta à pergunta de Locke - quis erit inter eos judex? - Os juízes são competentes para medir as leis segundo a medida da constituição. Eles são os "juízes" entre o povo e o legislador. ${ }^{204}$

O controle de constitucionalidade é realizado no Brasil de duas maneiras: em sede de controle abstrato, também chamado de concentrado, ou em sede de controle incidental, também conhecido como controle concreto ou difuso. Esse último esteve sempre presente nas Constituições Republicanas brasileiras, mas, o controle abstrato surgiu apenas em 1965, com uma Emenda à Constituição de 1946. Embora já existisse no ordenamento brasileiro a ação direta, essa visava apenas ao processo de intervenção nos estados. ${ }^{205}$

A Constituição de 1988 privilegiou o controle abstrato em detrimento do concreto, aumentando o rol de legitimados a propor as ações diretas, criando a argüição de descumprimento de preceito fundamental, além de ampliar também o objeto das ações diretas, uma vez que a Emenda Constitucional de 1993, e também a de 2004, equipararam a Ação Declaratória de Constitucionalidade à Ação Direta de Inconstitucionalidade, reconhecendo seu caráter dúplice. Além disso, passou-se a controlar a inconstitucionalidade por omissão por meio de instrumentos como o mandado de injunção e o habeas data. Essa espécie de controle tem efeito erga omnes, considerando que os legitimados a propor a ação o fazem em decorrência do interesse público, de modo que não caberia falar em efeito inter partes. Por isso também alguns defendem o uso da ação civil pública como um novo instrumento do controle de constitucionalidade, mas parte da doutrina rejeita essa ideia, pois seria atribuir ao juiz ordinário da primeira instância a competência do Supremo Tribunal Federal, vez que a decisão teria efeito erga omnes na prática. ${ }^{206}$

O controle concreto, por sua vez, possui uma série de obstáculos à decretação da inconstitucionalidade da norma, pois, diante do princípio da presunção de constitucionalidade, o seu afastamento deve ser realmente necessário, não podendo ser realizado diante do voluntarismo das partes. Em razão disso, obriga-se a reserva de Plenário, por exemplo, além da necessidade do cumprimento de alguns requisitos objetivos, que, se não cumpridos, podem levar à rejeição pelo órgão fracionário - antes mesmo de chegar ao

\footnotetext{
${ }^{204}$ CANOTILHO (1998, p. 53-54)

${ }^{205}$ MENDES; COELHO; BRANCO (2007, p. 1010 et seq.)

${ }^{206}$ MENDES; COELHO; BRANCO (2007, p. 1000 et seq.)
} 
Plenário: caso a suposta inconstitucionalidade não seja relevante para o julgamento da causa, caso o ato questionado não seja de natureza normativa ou não advenha do Poder Público, ou, ainda, caso o Supremo já tenha se manifestado no sentido da inconstitucionalidade. ${ }^{207}$

Além disso, a Emenda Constitucional $\mathrm{n}^{\circ} 45 / 04$ trouxe o instituto da repercussão geral, o qual estabelece um crivo de admissibilidade em que deve ser demonstrada a repercussão geral do tema a ser discutido. Caso essa não seja demonstrada, a palavra final do caso será dada pelo Tribunal Superior competente, e não pelo Supremo. Essa Emenda trouxe uma verdadeira mutação constitucional ao criar a Súmula Vinculante. Afinal, o papel que antes competia ao Senado Federal de dar efeito erga omnes à decisão de inconstitucionalidade em sede de controle concreto - segundo o disposto no art. 52, X da Constituição - passou a ser exercido pela Corte Suprema, que vislumbrou no exemplo americano do stare decisis, diante da inércia do Legislativo, a possibilidade de dar eficácia geral às suas decisões. ${ }^{208}$

Outra situação decorre de adoção de súmula vinculante (art. 103-A da CF, introduzido pela EC n.45/2004), na qual se afirma que determinada conduta, dada prática ou uma interpretação é inconstitucional. Nesse caso, a súmula acabará por dotar a declaração de inconstitucionalidade proferida em sede incidental de efeito vinculante. A súmula vinculante, ao contrário do que ocorre no processo objetivo, decorre de decisões tomadas em casos concretos, no modelo incidental, no qual também existe, não raras vezes, reclamo por solução geral. Ela só pode ser editada depois de decisão do Plenário do Supremo Tribunal Federal ou de decisões repetidas das Turmas. Desde já, afigura-se inequívoco que a referida súmula conferirá eficácia geral e vinculante às decisões proferidas pelo Supremo Tribunal Federal sem afetar diretamente a vigência de leis declaradas inconstitucionais no processo de controle incidental. E isso em função de não ter sido alterada a cláusula clássica, constante do art. 52, X, da Constituição, que outorga ao Senado a atribuição para suspender a execução de lei ou ato normativo declarado inconstitucional pelo Supremo Tribunal Federal. ${ }^{209}$

Isso nos traz um questionamento inevitável: a atuação do Supremo Tribunal Federal é jurídica ou política? Afinal, parece que, a depender do subjetivismo dos julgadores, são criadas estratégias para lhes fornecer a competência de julgar determinadas causas que lhes pareçam interessantes, enquanto outras são relegadas aos Tribunais Superiores.

Uma corte constitucional é, por definição, um órgão do judiciário ou diverso, cuja principal função é julgar a constitucionalidade de leis, emitindo pareceres sobre elas e decretos dos poderes Executivo e Legislativo, em consonância com correta aplicação da Constituição. Já uma suprema corte tem caráter de última instância, de corte de apelação. No Brasil, o Supremo

\footnotetext{
${ }^{207}$ MENDES; COELHO; BRANCO (2007, p. 1015 et seq.)

${ }^{208}$ MENDES; COELHO; BRANCO (2007, p. 1025 et seq.)

${ }^{209}$ MENDES; COELHO; BRANCO (2007, p. 1036-1037)
} 
Tribunal Federal - STF - não é autêntica corte constitucional, pois acumula funções de corte constitucional e suprema corte.

(...)

Uma importante discussão acerca do controle de constitucionalidade realizada no século passado ocorreu entre Carl Smith e Hans Kelsen. O primeiro, defensor do estado totalitário, apontou para a idéia de que o controle de constitucionalidade ficaria a cargo do chefe do Estado, pois caso tal tarefa fosse dada a uma corte constitucional, esse controle implicaria uma politização da justiça e uma judicialização da política. Hans Kelsen, criador da Teoria Pura do Direito, inspirou a redação da Constituição Austríaca de 1920, na qual foi criada a primeira corte constitucional que instituiu a tese de validade das leis atuando como "legislador negativo": não criar leis, mas ter a competência de julgá-la e retirá-la do ordenamento jurídico, revogando-a total ou parcialmente. ${ }^{210}$

Não nos parece, contudo, que o Supremo não seja, assim, uma Corte Constitucional. O que ocorre, de fato, e isso não pode ser negado, é um acúmulo de funções ainda que esse acúmulo possa ser criticado e possamos dizer que, ao acumular mais de uma função, o exercício delas é prejudicado - afinal, com a grande quantidade de processos a serem julgados e o direito à celeridade processual, expresso desde a Emenda $n^{\circ} 45 / 04$, a qualidade do julgamento pode ser prejudicada - e para isso surgem medidas como a repercussão geral. ${ }^{211}$ No entanto, ao exercer o controle abstrato, o Supremo se aproxima da função legislativa, ainda que como legislador negativo, exercendo, assim, papel político, como não poderia deixar de fazê-lo por ser guardião da Carta Política; mas, ao revisar decisões judiciais, ele atua como órgão judicial.

Registramos que, ao menos em relação aos tribunais constitucionais, o juízo de reprovação do ativismo judicial enquanto conduta que seria ofensiva ao dogma da separação de poderes, não é compartilhado por muitos juristas de expressão, como é o caso de Mauro Cappelletti, por exemplo, para quem, pela singular posição institucional de que desfrutam - situadas fora e acima da tradicional tripartição dos poderes -,as cortes constitucionais não podem ser enquadradas nem entre os órgãos jurisdicionais, nem entre os legislativos, nem muito menos entre os órgãos executivos, porque a elas pertence de fato uma função autônoma de controle constitucional, que não se identifica com nenhuma das funções próprias de cada um dos Poderes tradicionais, antes se projeta de várias formas sobre todos eles, para reconduzi-los, quando necessário, à rigorosa obediência das normas constitucionais. ${ }^{212}$

Não se pode, contudo, como já foi contemplado anteriormente no presente trabalho, exercer a jurisdição criativamente ao ponto de ir contra a norma que legitima essa atuação da Corte Suprema, a Constituição. Com esse fundamento sendo observado, não se deve temer as críticas, que viriam de qualquer maneira, pois "como observa De Page, citando

\footnotetext{
${ }^{210}$ LOHN (2009)

211 PELUSO (2010)

${ }^{212}$ COELHO (2010)
} 
outros clássicos, a controvérsia sobre a autoridade da jurisprudência é tão velha quanto o direito." ${ }^{213}$ Conforme análise de Inocêncio Coelho:

Um ligeiro passar de olhos sobre as decisões da jurisdição constitucional ilustra, sobejamente, o crescimento dessa legislação judicial em diversos sistemas jurídicos. No Brasil, sob aplausos de uns e críticas de outros, vemos a todo instante o STF criar direito novo, embora sempre com a cautela de anunciar que as normas emergentes dos seus julgados não surgiram do nada, antes foram apenas extraídas do próprio texto da Constituição, onde estavam insinuadas, latentes ou implícitas, como que à espera do momento de se mostrarem às claras. ${ }^{214}$

Além disso, segundo os ensinamentos de Konrad Hesse, a vontade de

Constituição deve preponderar sobre a vontade de poder daqueles responsáveis por manter a ordem jurídica, para que a Constituição se torne efetiva, in verbis:

(...) a força normativa da Constituição não reside, tão-somente, na adaptação inteligente a uma dada realidade. A Constituição jurídica logra converter-se, ela mesma, em força ativa, que se assenta na natureza singular do presente. Embora a Constituição não possa, por si só realizar nada, ela pode impor tarefas. A Constituição transforma-se em força ativa se essas tarefas forem efetivamente realizadas, se existir a disposição de orientar a própria conduta segundo a ordem nela estabelecida, se, a despeito de todos os questionamentos e reservas provenientes dos juízos de conveniência, se puder identificar a vontade de concretizar essa ordem. (...) pode-se afirmar que a Constituição converter-se-á em força ativa se fizerem-se presentes, na consciência geral - particularmente na consciência dos principais responsáveis pela ordem constitucional -, não só a vontade de poder (Wille zur Macht), mas também a vontade de Constituição (Wille zur Verfassung). ${ }^{215}$

No tocante ao Direito Internacional, as normas referentes a essa matéria também se encontram sujeitas ao controle de constitucionalidade, como sintetizou George Galindo, a ver:

Portanto, no Brasil, o controle de constitucionalidade, tanto difuso como concentrado, aplica-se também aos tratados internacionais. No caso do controle concentrado, a prática do Supremo Tribunal Federal tem considerado que, na verdade, o objeto do controle não é propriamente o tratado internacional, mas o Decreto Legislativo que o aprova e o Decreto do Executivo que o insere no ordenamento jurídico interno. Também é possível advogar a possibilidade de controle apenas do Decreto Legislativo, quando o tratado ainda não foi ratificado. ${ }^{216}$

Cabe lembrar, ainda, que também os atos advindos do Executivo estão sujeitos ao controle de constitucionalidade, e não apenas os do Legislativo. Pois, diante da nova concepção da tripartição dos poderes, observamos que o Executivo também legisla de certa

\footnotetext{
${ }^{213}$ DE PAGE apud COELHO (2010)

${ }^{214}$ COELHO (2010)

${ }^{215}$ HESSE apud LIMA (2010, p. 45-46)

${ }^{216}$ GALINDO (2001, p. 172)
} 
forma, ao criar normas como as medidas provisórias. De igual maneira, os demais poderes também exercem o controle de constitucionalidade prévio - o Legislativo antes de criar a norma e o Executivo, antes de criá-la ou de promulgá-la, pois só assim faz sentido a aplicação da presunção de constitucionalidade a atos do Poder Público.

De fato, a atividade legislativa destina-se, em última análise, a assegurar os valores e a promover os fins constitucionais. A atividade administrativa, tanto normativa quanto concretizadora, igualmente se subordina à Constituição e destina-se a efetivá-la. O Poder Judiciário, portanto, não é o único intérprete da Lei Maior, embora o sistema lhe reserve a primazia de dar a palavra final. ${ }^{217}$

Além disso, o Executivo exerce o controle de constitucionalidade preventivo em relação às normas internacionais, antes de ratificá-las - considerando que internacionalmente as normas só entram em vigor após a ratificação.

Caso assim considere, com o instrumento de ratificação, poderá opor reservas ao tratado - se o instrumento convencional assim prever - que podem servir como uma espécie de controle da constitucionalidade. Se há dúvidas acerca da constitucionalidade interna de determinada disposição convencional, é conveniente promover a ratificação com reservas. ${ }^{218}$

Os atos internacionais estão também sujeitos ao controle de constitucionalidade realizado pelo Judiciário, uma vez que, além de a Constituição consubstanciar o princípio da inafastabilidade do controle judicial, o sistema de freios e contrapesos exige a fórmula descrita a seguir:

Só é possível reconhecer Estado de Direito onde: a) o Estado se submete à jurisdição; b) a jurisdição deva aplicar a lei preexistente; c) a jurisdição seja exercida por uma magistratura imparcial (obviamente, independente), cercada de todas as garantias; d) o Estado a ela se submeta como qualquer pars, chamada a juízo em igualdade de condições com a outra pars. ${ }^{219}$

Nesse sentido, descreve bem o funcionamento harmônico dos poderes políticos, dentro cada um de seus limites, a situação exposta por Canotilho, in verbis:

A limitação do Estado pelo direito teria de estender-se ao próprio soberano: este estava também submetido ao império da lei (...) transformando-se em "órgão do Estado". No âmbito da actividade administrativa, fundamentalmente dedicada à defesa e seguranças públicas, os poderes públicos deviam actuar nos termos da lei (princípio da legalidade da administração) e obedecer a princípios materiais como, por exemplo, o princípio da proibição do excesso (...). Logicamente, estes princípios conduzem à exigência do controlo judicial da actividade da administração. ${ }^{220}$

\footnotetext{
${ }^{217}$ BARROSO (2008, p. 371)

${ }^{218}$ GALINDO (2001, p. 112)

${ }^{219}$ SUNDFELD (2006, p. 43)

${ }^{220}$ CANOTILHO (1998, p. 91)
} 
Para definir qual seria, então, a atividade fundamental do Executivo, isto é, administrar, Hobbes traz a explicação da formação do Estado, sem o qual, segundo ele, os homens, em seu estado natural, viveriam em uma constante guerra, baseando, então, a ideia de contrato social, como pode ser percebido na transcrição a seguir:

Porque as leis da natureza (como a justiça, a equidade, a modéstia, a misericórdia e, em suma, fazer aos outros o que gostaríamos que nos fizessem), por si mesmas, sem o terror de algum poder que as faça serem observadas, são contrárias às nossas paixões naturais, que nos levam à parcialidade, ao orgulho, à vingança e coisas semelhantes. E os pactos, sem a espada, nada mais são que palavras sem nenhuma força para proteger um homem. Por conseguinte, apesar das leis da natureza (que cada um cumpre quando tem vontade de cumprir, quando pode fazê-lo em segurança), se não houver um poder instituído, ou não houver um poder que seja grande o bastante para nossa segurança, cada homem confiará, e poderá legitimamente confiar em sua própria força e arte como proteção contra todos os outros homens.(...)

A única maneira de instituir um tal poder comum, capaz de defendê-los da invasão de estrangeiros e das injúrias uns dos outros, garantindo-lhes assim que, por meio de sua própria indústria e dos frutos da terra, possam nutrir-se e viver satisfeitos, é conferir todo seu poder e força a um homem ou a uma assembléia de homens, que possa reduzir todas as suas vontades, por pluralidade de votos, a uma única vontade... Isto é mais do que consentimento, ou concórdia, é uma verdadeira unidade de todos, numa única e mesma pessoa, realizada por um pacto de cada homem com cada homem, de maneira que seria como se cada homem dissesse a todo homem: autorizo e cedo meu direito de governar-me a este homem, ou a esta assembleia de homens, com a condição de cederes teu direito a ele, autorizando todas as suas ações da mesma maneira. Isso feito, a multidão assim unida numa pessoa é chamada de Estado, em latim civitas. $^{221}$

Diante de todo o exposto em relação à separação dos poderes, enfrentaremos uma das maiores críticas ao Direito Internacional: o fato de esse sistema jurídico não possuir órgãos centralizadores que exerçam cada uma das funções designadas ao poderes políticos Judiciário, Legislativo e Executivo.

A segunda tendência - (constitucionalização do direito internacional) - é talvez mais recente. Manifesta-se através da inspiração que a ordem constitucional oferece aos internacionalistas, abraçados, com fervor, à idéia de implantação de uma comunidade universal de Estados, devidamente institucionalizado. A Carta da Organização das Nações Unidas é desses documentos que sugerem a imitação ainda um tanto rude do modelo constitucional, como se estivesse a criar nos três órgãos básicos (1) Assembléia Geral - (2) Conselho de Segurança e - (3) Corte de Justiça. A imagem dos três poderes (legislativo, executivo e judiciário), que distinguem como seu perfil característico, a organização do Estado moderno. Escreve a esse respeito o professor Afonso Arinos de Melo Franco: "define-se, desta forma, o período que chamamos da constitucionalização do direito internacional." ${ }^{222}$

${ }^{221}$ HOBBES apud MORRIS (2002, p. 115)

${ }^{222}$ BRUNO NETO (s/d, p. 3-4) 
A começar pela dificuldade em se estabelecer um governo central, Kant já dispunha:

Mas com a extensão por demais grande de tal União de Estados sobre vastas regiões, qualquer governo dela e, por conseguinte, a proteção de seus membros individuais devem ao final tornar-se impossíveis; desse modo, uma grande quantidade de tais corporações restabeleceria de novo o estado de guerra. Por isso, a Paz Perpétua, que é a derradeira finalidade de todo o Direito das Gentes, se torna de fato uma ideia impraticável. Entretanto, não são impraticáveis os princípios políticos que visam tal fim e que recomendam a formação de tais uniões entre os Estados como meio de promover uma aproximação contínua da Paz Perpétua. ${ }^{223}$

O que Kant não previa era que as referidas corporações, além de não travarem entre si uma batalha em busca de poder, uma vez que costumam tratar de objetos ou de sujeitos distintos, por diversas vezes se aliam para, por meio da cooperação interestatal, alcançar metas maiores e mais significativas. Até mesmo porque, para combater crimes como, por exemplo, o terrorismo, o Estado, sozinho, se mostra fraco e ineficaz.

While greater investment in the security infrastructure is justified, it is also important to stress the limitations of material power illustrated by the chaos in "post war" Iraq, and the loss of trust in and good-will towards the US in the aftermath of the Iraq invasion. (...) Since then US military power in Iraq has been severely tested and it is questionable whether the US can even sustain its engagement in this single theatre for the time necessary to accomplish its goals. If anything has been revealed since 11 September 2001 , it is that material power is itself weak in many circumstances, and States need to pay attention to both their hard power assets and their capacity to influence through persuasive power. ${ }^{224}$

Dessa maneira, os Estados criam formas de regulação semelhantes às estatais para reger as relações internacionais, separando as normas a partir da matéria ou do objeto por meio das organizações supraestatais específicas. Como exemplo, tomaremos o comércio internacional, o qual, segundo parte da doutrina, é um dos maiores responsáveis pela existência do Direito Internacional em si.

Uma das características da sociedade internacional é a denominada globalização, isto é, uma economia integrada por obra das empresas transnacionais. Erich Weede (...) escreve: "globalização da economia significa que as fronteiras entre os países perdem importância, quando se trata de decisões sobre investimentos, produção, oferta, procura e financiamentos. As consequências são uma rede cada vez mais densa de entrelaçamento das economias nacionais, uma crescente internacionalização da produção, no sentido de que os diferentes componentes de um produto final possam ser manufaturados em diferentes países, e a criação de mercados mundiais integrados para inúmeros bens, serviços e produtos

${ }^{223}$ KANT apud MORRIS (2002, p. 258-259)

${ }^{224}$ BRUNNÉE; TOOPE (2004, p.788-789) 
financeiros. A globalização também abarca os mercados de trabalho. Aumentaram as migrações de mão-de-obra entre países. Nenhum país pode retirar-se da rede de integração econômica internacional sem, no mínimo, temporariamente, ocasionar perdas na assistência social para si e para os outros países. ${ }^{225}$

Com isso, o comércio internacional é caracterizado por compras e vendas entre agentes cujos estabelecimentos ou domicílios se encontram em Estados diferentes, nos termos da Convenção de Haia de 1964 e da Convenção de Viena de $1980 .^{226}$

Neste sentido, como existe a possibilidade de aplicação da lei de mais de um país, levanta-se a questão da escolha da lei aplicável pelas partes aos contratos internacionais e do princípio da autonomia da vontade. (...) No âmbito do Direito Internacional Privado, autonomia da vontade significa permitir que as partes escolham a lei aplicável ao contrato internacional. Essa possibilidade só existe no contrato internacional, pois nos contratos internos não é possível determinar qual o sistema jurídico que vai resolver suas questões. ${ }^{227}$

Assim, alguns ordenamentos permitem inclusive o dépeçage ou fracionamento, segundo o qual cada parte do contrato estará submetida a uma ordem jurídica diversa, sendo, por exemplo, a forma contratual regida pelas normas de um país e a execução, pelas leis de outro. $^{228}$ No Brasil, a Lei de Introdução ao Código Civil restringe a autonomia ao prever, no art. $9^{\circ}$, que serão aplicadas as leis do país em que as obrigações foram constituídas, mas, ao mesmo tempo, admite as peculiaridades da lei estrangeira. ${ }^{229}$ É clara também a atuação de organismos internacionais na formulação das fontes aplicáveis ao comércio internacional, determinando, inclusive, em que consistiria a chamada lex mercatoria, isto é, os usos e costumes do comércio internacional, além de positivar Incoterms, responsáveis por indicar os limites da obrigação do vendedor e do comprador.A esse respeito, escreve Carla Ventura:

Garcez (1994) assevera ainda a contribuição de alguns organismos privados internacionais, como a Câmara de Comércio Internacional (International Chamber of Commerce - ICC) que, com a finalidade de fornecer um conjunto de regras internacionais confiáveis para a utilização e interpretação dos termos negociais que envolvem as responsabilidades das partes quanto à entrega, embarque e transporte de mercadorias, vem, desde 1936, publicando e atualizando os INCOTERMS (International Rules for Interpretation of Trade Terms). ${ }^{230}$

A autora esclarece, ainda, que a autonomia da vontade abrange, inclusive, a escolha do tribunal competente para dirimir eventual litígio entre as partes, desde que a

\footnotetext{
${ }^{225}$ MELLO (2001, p. 56)

${ }^{226}$ VENTURA (2010, p. 113-114)

${ }^{227}$ VENTURA (2010, p. 97)

${ }^{228}$ VENTURA (2010, p. 99)

${ }^{229}$ LEI DE INTRODUÇÃO AO CÓDIGO CIVIL (BRASIL, 2002)

${ }^{230}$ VENTURA (2010, p. 96)
} 
referida escolha não ofenda à ordem pública. ${ }^{231} \mathrm{~A}$ partir disso, começamos a analisar o funcionamento do Poder Judiciário em âmbito internacional.

O Brasil, já no art. $7^{\circ}$ do Ato das Disposições Constitucionais Transitórias da atual Constituição se dispõe a lutar pela formação de um tribunal internacional que proteja os direitos humanos $^{232}$. Ora, esse dispositivo demonstra claramente a disposição nacional a se submeter à jurisdição internacional e isso pode ser comprovado pelo $\S 4^{\circ}$ do art. $5^{\circ}$, incluído pela Emenda Constitucional no 45/04, o qual prevê justamente a submissão à jurisdição de Tribunal Penal Internacional a cuja criação o Brasil tenha manifestado adesão. ${ }^{233}$ Isso faz com que o Brasil se submeta de maneira geral ao aderir à criação, e não tenha que confirmar a jurisdição diante de cada caso concreto, conforme entende parte da doutrina.

Deve-se ressaltar que a entrega de criminosos internacionais, com a qual o Brasil se compromete no âmbito do Tribunal Penal Internacional (TPI) não se confunde com a extradição e tampouco se trataria de efeito de uma sentença penal estrangeira, já que o TPI é um tribunal internacional, que, ipso facto, dita sentenças internacionais. ${ }^{234}$

Assim, cria-se, em âmbito internacional, uma jurisdição universal, como não poderia deixar de ser diante da forma pela qual o Estado Cooperativo se manifesta atualmente. Afinal, se caminhamos para o modelo de uma comunidade internacional, essa comunidade tem o direito de perseguir aqueles que a ofendem a partir dos seguintes elementos: a existência de valores comuns entre os membros dessa comunidade, a expansão dos mecanismos de tutela desses valores e a constatação de que essa tutela puna e previna outras ofensas, de modo a assegurar a ordem mundial, a justiça e a paz. ${ }^{235}$

A teoria da jurisdição universal é estranha ao conceito de soberania nacional, a qual se configura como raiz histórica da jurisdição nacional. A jurisdição universal (...) transcende a soberania nacional.

Dessa forma, os Estados exercem a jurisdição universal, não apenas como jurisdição nacional, mas como sub-rogação da comunidade internacional. Em outras palavras, um Estado, ao exercer a jurisdição universal, realiza uma action popularis contra pessoas consideradas hostis humani generis. ${ }^{236}$

Assim, surge a Corte Internacional de Justiça, a fim de concretizar a persecução àqueles que ofendem os valores expressos pela comunidade internacional. $\mathrm{O}$ Estado inerte diante de uma violação aos direitos humanos, por exemplo, pode ser condenado a tomar providências para repressão aos violadores, além de prestar assistência, compensação

\footnotetext{
${ }^{231}$ VENTURA (2010, p. 97)

${ }^{232}$ ATO DAS DISPOSIÇÕES CONSTITUCIONAIS TRANSITÓRIAS (BRASIL, 1988)

${ }^{233}$ CONSTITUIÇÃO FEDERAL (BRASIL, 1988)

${ }^{234}$ PEREIRA ([2010?], p. 9)

${ }^{235}$ JANKOV (2009, p. LI)

${ }^{236}$ JANKOV (2009, p, L)
} 
- pecuniária e no sentido de fazer justiça para garantir a construção da memória individual e coletiva - e proteção às vítimas, além, claro, de garantir a cessação da violação. ${ }^{237}$ Cabe à Corte Internacional de Justiça definir, também, quais são os valores protegidos, pois, segundo Bobbio, “(...) os súditos se tornam cidadãos quando lhes são reconhecidos alguns direitos fundamentais; haverá paz estável, uma paz que não tenha a guerra como alternativa, somente quando existirem cidadãos não mais apenas deste ou daquele Estado, mas do mundo,"238

As the principal judicial organ of public international law, the International Court of Justice contributes to the understanding of the fundamental values of the international community expressed in international humanitarian law. Judicial decisions as such are not a source of law, but the dicta by the International Court of Justice are unanimously considered as the best formulation of the content of international law in force. ${ }^{239}$

Com isso, percebe-se a presença de interesses cuja defesa extrapola a órbita estatal, dentre os quais se encontrariam os direitos humanos. Outros entendem que as Constituições dos próprios Estados já garantem a cooperação entre si e trazem instrumentos para assegurar o exercício dos direitos fundamentais, como seria exemplo a Constituição brasileira de 1988, sendo dispensável a criação de novos institutos para essa proteção. ${ }^{240}$

\subsection{A MODIFICAÇÃO REALIZADA PELA EMENDA CONSTITUCIONAL NÚMERO 45/2004}

Como foi demonstrado no tópico anterior, a Emenda Constitucional $n^{\circ} 45 / 04$, também conhecida como a Reforma do Judiciário, trouxe diversas inovações relevantes ao nosso estudo - seja a transferência da competência para homologação de sentenças e concessão do exequatur de cartas rogatórias, as alterações no controle de constitucionalidade concentrado, a criação do instituto da repercussão geral e da súmula vinculante, a submissão a Tribunal Penal Internacional ou a previsão da celeridade no processo judicial como um direito. Abordaremos neste tópico as alterações especificamente trazidas pela adição do $\S 3^{\circ}$ do art. $5^{\circ}$, analisando também como era anteriormente.

$\mathrm{O} \S 2^{\circ}$ do mesmo artigo já trazia a seguinte redação, desde a promulgação da Constituição, em 1988: “Os direitos e garantias expressos nesta Constituição não excluem

\footnotetext{
${ }^{237}$ LIMA (2010, p. 24-25)

${ }^{238}$ BOBBIO (1992, p. 1)

${ }^{239}$ CHETAIL (2003, p. 235)

${ }^{240}$ LIMA (2010, p. 52)
} 
outros decorrentes do regime e dos princípios por ela adotados, ou dos tratados internacionais em que a República Federativa do Brasil seja parte."241 ${ }^{24}$ deixando claro que o rol de direitos expressos no art. $5^{\circ}$ era meramente exemplificativo.

Com isso, o dispositivo possibilitava a interpretação segundo a qual as normas internacionais referentes a direitos humanos teriam status de norma constitucional. Além disso, essa espécie de tratado teria aplicação imediata, ou seja, logo após sua ratificação, o que levaria o Decreto Executivo que o promulga a perder sua natureza de ato de transformação, passando a ser mero ato de publicação, em razão do $\S 1^{\circ}$ - que dispunha que as normas que definissem direitos e garantias fundamentais teriam aplicação imediata. ${ }^{242} \mathrm{Em}$ interpretação a contrario sensu, os tratados que não se referissem a direitos humanos não teriam essas prerrogativas, isto é:

O regime jurídico diferenciado conferido aos tratados de direitos humanos não é, todavia, aplicável aos demais tratados, isto é, aos tratados tradicionais. No que tange a estes, adota-se a sistemática da incorporação legislativa, de modo a exigir que, após a ratificação, um ato com força de lei (no caso brasileiro este ato é um Decreto expedido pelo Executivo) confira execução e comprimento aos tratados no plano interno. ${ }^{243}$

Não se contesta a necessidade da publicidade que é dada à norma internacional por meio do Decreto Executivo. Afinal, somente a partir de então é que a norma será conhecida e invocada em âmbito nacional. A publicação do Decreto Legislativo não alcança esse efeito porque o consentimento ao cumprimento da norma pelo Estado ainda não se completou, pois ele apenas ocorre com a ratificação, quando a norma entra em vigor internacionalmente. $^{244}$ A própria Convenção de Viena de 1969 previu que a inconstitucionalidade extrínseca, isto é, a ratificação imperfeita, celebrada por agente incompetente ou sem a aprovação do Legislativo, é vício que gera a nulidade da norma, por manifestamente violar norma de direito interno de importância fundamental - no caso brasileiro, normas constitucionais - ofendendo a boa-fé. ${ }^{245}$

Por óbvio, o indivíduo, pelas implicações decorrentes do princípio da legalidade, só é obrigado a algo após a publicação da norma. No entanto, como ninguém pode se beneficiar de sua própria torpeza, o Estado não pode usar sua inércia a fim de se livrar do cumprimento das normas a que havia se comprometido. Por isso, conclui-se que, ainda que a norma não tenha sido publicada, ela pode ser invocada judicialmente para proteger o

\footnotetext{
${ }^{241}$ CONSTITUIÇÃO FEDERAL (BRASIL, 1988)

${ }^{242}$ GALINDO (2001, p. 121)

${ }^{243}$ PIOVESAN apud GALINDO (2001, p. 121)

${ }^{244}$ GALINDO (2001, p. 122)

${ }^{245}$ GALINDO (2001, p. 159 et seq.)
} 
indivíduo, mas não para obrigá-lo. ${ }^{246}$ Isso faz com que adotemos a posição de Mirtô Fraga, consonante com Rezek e outros doutrinadores, no tocante à natureza do Decreto Executivo seja em matéria de direitos humanos ou não, in verbis:

(...) O decreto de promulgação é o atestado de existência de uma regra jurídica, regularmente concluída, em obediência ao processo específico, instituído na Lei Maior. Se a promulgação não integra o processo legislativo, se, ao contrário, ela lhe é posterior - o que se promulga já é lei -, não se pode, logicamente, afirmar-se que o tratado promulgado por decreto do Executivo deixa, no âmbito interno do Estado, de ser Direito Internacional, para ser disposição legislativa interna. O que acontece é o seguinte: assinado o tratado, aprovado pelo Legislativo, ratificado pelo Executivo, ele passa, conforme o que se estabeleceu no seu próprio texto, a vigorar na órbita internacional. Os indivíduos, porém, para acatá-lo e os Tribunais para aplicálo precisam ter conhecimento de que ele existe. Pela promulgação, o Chefe do Poder Executivo apenas declara, atesta, solenemente, que foram cumpridas as formalidades exigidas para que o ato normativo se completasse. Mas, como afirma José Afonso da Silva, fazer saber que há uma norma jurídica pouco adiantaria se não se divulgasse tal comunicação. Isso se faz com a publicação. E como é ela que dá conhecimento a todos da existência da norma recém-formulada, e como só se é obrigado à norma que se conhece (a publicação faz presumir conhecimento), o tratado só é obrigatório a partir da data de inserção, no Diário Oficial da União, do decreto de promulgação, contendo em apenso o tratado.

Uma vez publicado, com o decreto, o tratado deve ser observado pelos particulares, aplicado pelos Tribunais. Na afirmativa de Rousseau, o tratado é obrigatório, em virtude de ratificação; executório, em face da promulgação; aplicável, em consequiência da publicação. ${ }^{247}$

Passando a analisar a questão da aplicabilidade imediata das normas internacionais que versem acerca de direitos humanos, é louvável a tentativa do constituinte em dar efetividade ao texto que havia escrito, conferindo materialidade e acabando com o caráter non-self executing de direitos antes meramente formais. As normas deveriam funcionar da seguinte maneira:

O significado essencial dessa cláusula é ressaltar que as normas que definem direitos fundamentais são normas de caráter preceptivo, e não meramente programático. Explicita-se, além disso, que os direitos fundamentais se fundam na Constituição, e não na lei - com o que se deixa claro que é a lei que deve mover-se no âmbito dos direitos fundamentais, não o contrário. Os direitos fundamentais não são meramente normas matrizes de outras normas, mas são também, e sobretudo, normas diretamente reguladoras de relações jurídicas. ${ }^{248}$

\footnotetext{
${ }^{246}$ GALINDO (2001, p. 124)

${ }^{247}$ FRAGA apud GALINDO (2001, p. 116-117)

${ }^{248}$ MENDES; COELHO; BRANCO (2007, p. 241)
} 
Não se trata de autorização constitucional para infringir o procedimento previsto para a adoção do tratado - como parte da doutrina entende, que estaria isenta da aprovação pelo Parlamento, estendendo a noção de aplicação imediata ao plano formal. ${ }^{249}$

Cabe lembrar, ainda, que o $\S 1^{\circ}$ trata de toda e qualquer norma de direito fundamental, e não apenas daquelas inseridas no ordenamento por meio de tratados internacionais. Tem-se de reconhecer, no entanto, que nem sempre é possível aplicar o referido parágrafo em situações práticas, pois, independente da vontade do constituinte, às vezes a natureza do direito resguardado exige a interferência do legislador para sua aplicação.

A inteligência do art. $5^{\circ}, \S 1^{\circ}$, da Constituição não pode fazer-se sem atenção à natureza das coisas, consoante lição de Manoel Gonçalves Ferreira Filho, que adverte: "pretender que uma norma incompleta seja aplicada é desejar uma impossibilidade, ou forçar a natureza que, rejeitada, volta a galope".

Por isso, sustenta Celso Bastos que, quando a norma de direito fundamental não contiver os elementos mínimos indispensáveis que lhe assegurem aplicabilidade, nos casos em que a aplicação do direito pelo juiz importar infringência à competência reservada ao legislador, ou ainda quando a Constituição expressamente remeter a concretização do direito ao legislador, estabelecendo que o direito apenas será exercido na forma prevista em lei -, nessas hipóteses, o princípio do $\S 1^{\circ}$ do art. $5^{\circ}$ da CF haverá de ceder.

Essas circunstâncias levam a doutrina a entrever no art. $5^{\circ}, \S 1^{\circ}$, da Constituição Federal uma norma-princípio, estabelecendo uma ordem de otimização, uma determinação para que se confira a maior eficácia possível aos direitos fundamentais. O princípio em tela valeria como indicador de aplicabilidade imediata da norma constitucional, devendo-se presumir a sua perfeição, quando possível. (grifos nossos) $)^{250}$

Em razão da suposta inoperância das normas internacionais, alguns autores alegam que esse ramo do Direito mais se assemelharia à aplicação de normas morais, e não jurídicas. Não se deve confundir, no entanto, eficácia e existência ou validade.

É óbvio que, se uma norma é absolutamente desrespeitada por todos, não se
pode dizer que ela exista. Mas se ela for parcialmente desrespeitada, ou
geralmente respeitada, então não se pode pôr em dúvida sua validade ou sua
natureza jurídica, pois isso é o que acontece normalmente com muitas
normas jurídicas que compõem os direitos nacionais internos. Admite-se,
contudo, que um sistema legal só possui essa qualidade se a generalidade de
suas normas for habitualmente respeitada e aplicada, i.e., se ele for, de uma
forma geral, eficaz. A tese que parece ser mais correta é que, a despeito das
suas deficiências institucionais, o conjunto de normas que compreende o
direito internacional é relativamente eficaz. ${ }^{251}$

${ }^{249}$ GALINDO (2001, p. 221) O doutrinador demonstra como Roberto Augusto Castellanos Pfeiffer e Anna Carla Agazzi levam a aplicabilidade imediata da norma ao plano formal. Mas, nesse caso, se não observada a aprovação parlamentar, a norma estará eivada de vício formal, passando a ter uma ratificação imperfeita, o que poderia ser considerado como vício de nulidade, e isso não interessa a ninguém, muito menos àqueles que defendem a efetividade dos direitos humanos.

${ }^{250}$ MENDES; COELHO; BRANCO (2007, p. 243)

${ }^{251}$ SOUZA (1999, p. 222) 
Alexy caracteriza os direitos humanos como sendo normas morais, sim, mas no sentido de que sua validade independe de positivação, ou seja, elas são justificáveis racionalmente. Além disso, os direitos humanos seriam normas universais, preferenciais ou prioritárias na ordem jurídica em que são acolhidas, fundamentais ou essenciais ao ser humano e abstratos. ${ }^{252}$ Assim, passamos a nos questionar o que poderia ser considerado como norma de direito humano. Na definição de Roberto Luquini:

O conceito atual dos direitos humanos se compõe dos clássicos direitos civis e políticos, ou seja, das liberdades públicas, dos direitos econômicos, sociais e culturais que obrigam o Estado a tomar medidas positivas para a satisfação das necessidades humanas no âmbito econômico, social e cultural e dos novos direitos que surgiram diante das demandas do mundo atual. Existe uma interdependência entre esses direitos, pois cada um deles e cada uma de suas categorias demanda para sua existência o reconhecimento e a vigência dos demais. ${ }^{253}$

$\mathrm{O}$ autor ressalta em seguida que tais direitos deveriam ser protegidos e promovidos pelo Estado, mas que, como, em alguns casos, é o próprio Estado que os viola e, em razão disso, os indivíduos passaram a ser considerados como sujeitos de direito com capacidade postulatória em relação aos direitos humanos ${ }^{254}$-, a intervenção do Direito Internacional se faz necessária - os direitos humanos passaram a ser matéria de regulação concomitante dessas duas esferas, e não de uma em detrimento da outra. Não é mais possível aplicar, então, o chamado domínio reservado, segundo o qual "o Estado reclamado tenta impedir a consideração de uma matéria a nível internacional alegando que ela recai essencialmente em seu domínio reservado ou competência nacional" ${ }^{255}$, ou, ainda, que os recursos internos e, portanto, a chance de o Estado reparar a violação por si, não se esgotaram. "É possível mesmo dizer que (...) referido direito à institucionalização converteu-se em parte integrante da ordem pública internacional. O caráter de norma consuetudinária que possui atribuiu-lhe o sentido de norma imperativa, que vincula os indivíduos e governos."256

Contudo, não se devem confundir os direitos humanos com o direito humanitário. De certo, eles advêm da mesma base: a proteção ao indivíduo. No entanto, enquanto os primeiros devem ter eficácia a todo tempo, o segundo tipo somente se justifica em tempos de guerra, pois possui natureza complementar e regulamenta essa situação de exceção a fim de evitar absurdos. Não quer dizer que um deva ser aplicado em detrimento do outro, pois, mesmo em tempos de guerra, os Estados possuem a obrigação de assegurar os

\footnotetext{
${ }^{252}$ ALEXY apud AMARAL JÚNIOR (2002, p. 51-52)

${ }^{253}$ LUQUINI (2003, p. 138)

${ }^{254}$ AMARAL JÚNIOR (2002, p. 56)

${ }^{255}$ TRINDADE apud SANTOS (2011, p. 20)

${ }^{256}$ AMARAL JÚNIOR (2002, p.52)
} 
direitos humanos a seus cidadãos, quando, na verdade, se fazem ainda mais necessários. ${ }^{257}$ "The key here is to avoid sacrificing important civil liberties values, some of the very values for which the unfortunately named 'war of terror' is said to be fought.",258

Tanto os tribunais internos quanto os internacionais podem delimitar o que seria tido por direito humano. Esses, normalmente, aplicam um sentido mais ampliador de direitos, levando em consideração não apenas as práticas internacionais, mas também a interação entre essas e os diversos Direitos internos, como os mais variados países tratam a questão. ${ }^{259}$ Desse modo, segundo Gros Espiell:

Sus fuentes se encuentran en la Carta de Naciones Unidas, en la Declaración Universal de Derechos Humanos, en los dos Pactos Internacionales de Derechos Humanos, en el Protocolo Facultativo al Pacto de Derechos Civiles y Políticos y en una larga seria de instrumentos, convencionales o no, elaborados en el ámbito de las Naciones Unidas y de algunos de sus organismos especializados, particularmente de la OIT y de la UNESCO. Pero a todos estos textos de carácter universal se suman los documentos internacionales de tipo regional, como la Convención Europea de Salvaguardia de los Derechos del Hombre y de las Libertades Fundamentales, la Carta Social Europea, la Declaración Americana de Derechos y Deberes del Hombre, la Convención Americana de Derechos Humanos y, entre otros, los textos nacidos de la liga de Estados árabes y de la Organización de Unidad Africana. ${ }^{260}$

Os direitos humanos "nacen con la modernidad en el seno de la atmósfera intelectual que inspirará las revoluciones liberales del siglo XVIII."261 Ao longo da história, encontram-se movimentos que os justificam a partir de doutrinas como o jusracionalismo, postulando: "todos los seres humanos desde su propria naturaleza poseen unos derechos naturales que dimanan de su racionalidad, en cuanto rasgo común a todos los hombres, y que esos derechos deben ser reconocidos por el poder político a través del derecho positivo."262 Complementa, ainda, o mestre: "En las fases anteriores se podrá hablar de derechos de príncipes, de etnias, de estamentos o de grupos, pero no de derechos humanos en cuanto facultades jurídicas de titularidad universal."263

A proliferação dos direitos humanos se deu após a Segunda Guerra Mundial em três sentidos: a quantidade de bens tutelados aumentou - se antes a proteção se referia apenas à liberdade, agora se exige uma postura positiva do Estado para garantir os direitos

\footnotetext{
${ }^{257}$ LUQUINI (2003, p. 138 et seq.)

${ }^{258}$ BRUNNÉE; TOOPE (2004, p. 789)

${ }^{259}$ GALINDO (2001, p. 250-251)

${ }^{260}$ ESPIELL apud LUQUINI (2003, p. 138-139)

${ }^{261}$ PÉREZ LUÑO (2002, p. 23)

${ }^{262}$ PÉREZ LUÑO (2002, p. 23)

${ }^{263}$ PÉREZ LUÑO (2002, p. 24)
} 
políticos e sociais e até mesmo os chamados "direitos de terceira geração"; alguns direitos extravasaram a esfera do homem em si, considerando até mesmo as futuras gerações; e a especificidade de cada indivíduo (idoso, criança, deficiente,...) que exige maior proteção passou a ser levada em consideração. ${ }^{264}$ "Se siente hoy, con mayor intensidad que en cualquier etapa histórica precedente, la exigencia de que los derechos y las libertades no se vean comprometidos por el tránsito de las fronteras estatales."265

Não podemos aprisionar as futuras gerações a valores que a presente geração reconheceu como fundamentais. Bem como não podemos deixar de observar que a garantia de determinados direitos às gerações futuras depende de ações ou omissões das gerações presentes. Assim é que, por exemplo, para garantir o direito à paz para as futuras gerações é importante que haja a omissão das gerações presentes no sentido da não proliferação de armas nucleares; bem como é imperioso para que se garanta um meio ambiente ecologicamente equilibrado às gerações futuras, que as gerações presentes atuem na redução da emissão de gás carbônico na atmosfera. ${ }^{266}$

Em razão disso, parte da doutrina, a que se vincula Sylvia Helena de Figueiredo Steiner, considera que os direitos humanos possuem caráter de norma materialmente constitucional, tendo de ser assim considerada - ou seja, com status e proteção constitucionais, ainda que não houvesse a previsão do $\S 2^{\circ}$ do art. $5^{\circ}$, uma vez que as normas de direitos humanos possuiriam a natureza de norma de ius cogens. ${ }^{267}$ Vale lembrar também que a redação do dispositivo em estudo encontra guarida desde a primeira Constituição brasileira republicana, a qual, em 1891, em seu art. 78, já consagrava fórmula semelhante. ${ }^{268}$

Nesse contexto, mesmo conscientes de que os motivos que conduzem à concepção de um Estado Constitucional Cooperativo são complexos, é preciso reconhecer os aspectos sociológico-econômico e ideal-moral como os mais evidentes. E no que se refere ao aspecto ideal-moral, não se pode deixar de considerar a proteção aos direitos humanos como a fórmula mais concreta de que dispõe o sistema constitucional, a exigir dos atores da vida sócio-política do Estado uma contribuição positiva para a máxima eficácia das normas constitucionais que protegem a cooperação internacional amistosa como princípio vetor das relações entre os Estados Nacionais e a proteção dos direitos humanos como corolário da própria garantia da dignidade da pessoa humana. ${ }^{269}$

Desse modo, o dispositivo em cotejo é, na verdade, uma cláusula de abertura da Constituição a novos direitos fundamentais, como não poderia deixar de ser, pois, no mundo cooperativo em que vivemos, novos direitos se fazem necessários a partir de situações

\footnotetext{
${ }^{264}$ BOBBIO apud AMARAL JÚNIOR (2002, p. 54)

${ }^{265}$ PÉREZ LUÑO (2002, p. 27)

${ }^{266}$ LAMARÃO (2009)

${ }^{267}$ STEINER apud GALINDO (2001, p. 222-223)

${ }^{268}$ GALINDO (2001, p. 230)

${ }^{269}$ VALE; MENDES (2009)
} 
antes inimagináveis. "Segundo a lição de Scheuner, citada por Häberle, a Constituição, para ter preservada sua força regulatória em uma sociedade pluralista, não pode ser vista como texto acabado ou definitivo, mas sim como 'projeto' em desenvolvimento contínuo."270

Tiene razón Habermas cuando indica que la modernidad constituye um proyecto inacabado, y que em lugar de abandonar esse proyecto como una causa perdida, deberíamos aprender de los errores de aquellos programas extravagantes que trataron o tratan de negar la modernidad. ${ }^{271}$

Não se pode confundir, por sua vez, o pluralismo ou multiculturalismo com o relativismo dos direitos humanos, pois esse último é prejudicial e reduziria a proteção devida, levando a crer que tudo pode ser feito em nome de uma cultura diversa, como explica Pérez Luño: "El pluralismo cultural, o sea el reconocimiento de una realidad plural de tradiciones e instituciones políticas y culturales, no debe confundirse con el relativismo cultural, es decir, con el mito de que todas las formas culturales poseen idéntico valor." ${ }^{272}$ Assim, não encontra guarida a alegação chinesa em meio à Conferência Internacional de Direitos Humanos de 1993 de que "nações com diferentes graus de desenvolvimento econômico e tradições culturais teriam concepções distintas dos direitos humanos." $273 \mathrm{O}$ mestre segue explicando: "Es evidente que el relativismo cultural no puede servir de pantalla ocultadora de violaciones sistemáticas de los derechos humanos, ni de cômodo expediente legitimador para la impunidad de tiranos y déspotas." 274 Alberto do Amaral Júnior conclui, sintetizando, enfim, a solução: “A realização de diálogos interculturais, que identifiquem constelações axiológicas comuns nas diferentes culturas, é a única forma apta a propiciar a consolidação dos elos sociais que definem, em última instância, a eficácia internacional dos direitos humanos."275

De qualquer maneira, para evitar qualquer dúvida dos operadores do direito em relação à constitucionalidade dos tratados de direitos humanos no ordenamento jurídico brasileiro, o constituinte derivado trouxe, por meio da Emenda Constitucional $n^{\circ} 45 / 04$, o $\S 3^{\circ}$ do art. $5^{\circ}$, com a redação: "Os tratados e convenções internacionais sobre direitos humanos que forem aprovados, em cada Casa do Congresso Nacional, em dois turnos, por três quintos dos votos dos respectivos membros, serão equivalentes às emendas constitucionais. ${ }^{, 276}$ Em meio ao Direito comparado, podemos ver que não somos os únicos a dar tratamento especial as normas de direitos humanos internacionais.

\footnotetext{
${ }^{270}$ VALE; MENDES (2009)

${ }^{271}$ PÉREZ LUÑO (2002, p. 47)

${ }^{272}$ PÉREZ LUÑO (2002, p. 41)

${ }^{273}$ AMARAL JÚNIOR (2002, p. 57)

${ }^{274}$ PÉREZ LUÑO (2002, p. 40)

${ }^{275}$ AMARAL JÚNIOR (2002, p. 60)

${ }^{276}$ CONSTITUIÇÃO FEDERAL (BRASIL, 1988)
} 
A Constituição da Nicarágua, em seu art. 182, prevê, de fato, que os tratados são inferiores à Constituição. Todavia, no que diz respeito aos tratados de Direitos Humanos, estabelece, em seu art. 46, o caráter constitucional de direitos consagrados em alguns tratados de Direitos Humanos - inclusive a Convenção Americana, justamente no capítulo sobre Direitos Individuais. ${ }^{277}$

A doutrina protestava contra a promulgação desse parágrafo, não por não desejar maior proteção aos direitos humanos, mas por considerá-lo desnecessário, já que as normas internacionais que tratassem dessa matéria já teriam status de norma constitucional pela aplicação do $\S 2^{\circ}$.

É equivocada a associação entre a inclusão de direitos fundamentais em virtude de uma cláusula aberta e as emendas constitucionais. Os tratados de Direitos Humanos não retiram seu status constitucional do iter legislativo em que são aprovados, quer ele exija quorum qualificado para a aprovação ou não. Este status é retirado, primeiramente, de sua natureza internacional e; segundamente, da matéria regulada, qual seja, concernente aos direitos fundamentais, o que leva a crer que, por conta disto, são normas materialmente constitucionais. ${ }^{278}$

Com a nova Emenda, surgem três espécies de tratados internacionais: aqueles que não tratam de direitos humanos; aqueles que tratam de direitos humanos, mas que não passaram pelo trâmite legislativo previsto no $\S 3^{\circ}$ por serem anteriores a ele - mas que a melhor doutrina considera que tenham status de norma materialmente constitucional em razão do $\S 2^{\circ}-$; e aqueles que tratam de direitos humanos e foram aprovados segundo os termos do $\S 3^{\circ}$ - ou seja, com quórum de aprovação igual ao de Proposta de Emenda à Constituição (art. $60, \S 2^{\circ}$ ) para lhe dar status formal de norma constitucional. ${ }^{279}$

Assim, o $\S 3^{\circ}$, que veio para dirimir dúvidas, acaba tendo mais de uma interpretação: a primeira, seguida pela melhor doutrina, considera que ele é mera norma interpretativa e que veio dar maior segurança jurídica ao $\S 2^{\circ}$ apenas, mas isso não influenciaria na hierarquia das normas internacionais promulgadas antes dele. A segunda gera a inconstitucionalidade parcial dessa Emenda Constitucional, uma vez que trata o $\S 3^{\circ}$ como instrumento tendente a abolir os direitos fundamentais que haviam sido incorporados ao ordenamento brasileiro antes de sua promulgação, apenas por não terem seguido o quórum de Emendas Constitucionais. Além disso, limitaria também o alcance do $\S 2^{\circ}$. Tendo em vista que os direitos fundamentais são cláusulas pétreas segundo o $§ 4^{\circ}$ do art. 60 da Constituição, e havendo uma inconstitucionalidade entre eles e o $\S 3^{\circ}$ do art. $5^{\circ}$, entende-se que, segundo essa

\footnotetext{
${ }^{277}$ GALINDO (2001, p. 234)

${ }^{278}$ GALINDO (2001, p. 244)

${ }^{279}$ LIMA (2010, p. 47)
} 
interpretação, ele seria inconstitucional. ${ }^{280}$ O Supremo já entendeu como possível também o controle de constitucionalidade de emendas constitucionais quando em conflito com cláusulas pétreas, conforme se depreende do julgamento da ADI $939 .^{281}$

De qualquer maneira, o que não se pode negar é que os tratados de direitos humanos são cláusulas pétreas, pois são normas de estatura constitucional referentes a direitos fundamentais. Parte da doutrina enxerga nesse ponto uma distinção útil possível ao $\S 3^{\circ}$ :

Como decorrência lógica da distinção entre tratados material e formalmente constitucionais, os direitos decorrentes dos tratados internacionais formalmente incorporados pelo procedimento das emendas constitucionais, descrito no art. $5^{\circ}$, parágrafo $3^{\circ}$, constituem cláusulas pétreas, sendo vedada qualquer tentativa de abolição deles, conforme o art. 60 , parágrafo $4^{\circ}$, da $\mathrm{CF} / 88$; o que não ocorre no caso dos tratados incorporados pelo procedimento do parágrafo $2^{\circ}$, estes sim, ainda suscetíveis de denúncia no plano internacional. ${ }^{282}$

A possibilidade de denúncia dos tratados de direitos humanos, ainda que anteriores ao $\S 3^{\circ}$, não é pacífica, pois, são considerados como tratados de hierarquia constitucional e "do ponto de vista do Direito Constitucional, a denúncia se assemelha, em seus efeitos, a uma emenda supressiva, agravada pelo fato de que, no Brasil, a denúncia dos Tratados é de competência exclusiva do Chefe do Executivo". ${ }^{283}$ Dessa forma, seria uma Emenda supressiva de direito fundamental sem passar por aprovação parlamentar, o que seria inaceitável. A doutrina admite apenas a denúncia sem efeito, pois, de qualquer maneira, os direitos já estariam incorporados ao ordenamento, o que também não faz sentido. ${ }^{284}$

Uma boa solução para esse conflito entre normas seria a aplicação da norma mais favorável à vítima, fosse essa norma interna ou internacional, já que ambas têm o mesmo objetivo: a proteção do ser humano. Diversas vantagens advêm da aplicação desse método, segundo Cançado Trindade, quais sejam: reduz a possibilidade de conflitos entre instrumentos legais; obtém uma maior coordenação entre eles, seja na dimensão vertical - tratados e direito interno - ou horizontal - tratados entre si, lembrando-se que não se pode descumprir um tratado em detrimento de outro; e fortalece a proteção a partir da coexistência de instrumentos. ${ }^{285}$ Assim, seria aplicado o mesmo método utilizado para garantir a unidade da

\footnotetext{
${ }^{280}$ LIMA (2010, p. 48-49)

${ }^{281}$ GALINDO (2011, p. 237)

${ }^{282}$ LIMA (2010, p. 47)

${ }^{283}$ GALINDO (2001, p. 246)

${ }^{284}$ GALINDO (2001, p. 247)

${ }^{285}$ GALINDO (2001, p. 216)
} 
Constituição quando se encontram normas em conflito aparente: a ponderação em cada caso concreto para analisar qual prevalecerá e qual será relativizada. ${ }^{286}$

O ponto fulcral desta terceira corrente defendida aqui é a aceitação da compatibilidade das normas constitucionais com a normatividade internacional de proteção aos direitos humanos como presunção absoluta, em face dos princípios da Constituição de 1988. Isso porque a Constituição Brasileira atual, ao estabelecer um Estado Democrático de Direito e o apego à primazia dos direitos fundamentais da pessoa humana, não pode ser vista como obstáculo a uma maior proteção da pessoa humana, obtida em dispositivos internacionais. ${ }^{287}$

O Brasil ainda não aceita amplamente essa corrente, como veremos adiante, por meio de seus tribunais, mas a Convenção Americana de Direitos Humanos, em seu art. 29-b, traz essa possibilidade, ainda que seja pela prevalência de norma interna em confronto com a referida Convenção, mostrando que o Direito Internacional prefere a proteção do indivíduo a questões formalistas - exemplo esse que deveria ser seguido pelo nosso país. ${ }^{288}$

\subsection{A MUDANÇA DE ENTENDIMENTO DO SUPREMO TRIBUNAL FEDERAL E SUA APLICAÇÃO}

Ao longo de sua história, o Supremo Tribunal Federal modificou o seu entendimento, não apenas na questão de que trataremos aqui, mas também em diversas outras matérias. Nisso não há mal algum, pois, partindo-se da premissa colocada por Häberle de que a hermenêutica é uma atividade historicamente situada - pois a norma tem seu significado alterado de acordo com as experiências em que se situa -, a mutação normativa ou de interpretação pode declarar a inconstitucionalidade de situações anteriormente consideradas legítimas e vice-versa.

A orientação doutrinária tradicional, marcada por uma alternativa rigorosa entre atos legítimos ou ilegítimos (...), encontra dificuldade para identificar a consolidação de um processo de inconstitucionalização (Prozess des Verfassungswidrigwerdens). Prefere-se admitir que, embora não tivesse sido identificada, a ilegitimidade sempre existira. ${ }^{289}$

Isso não quer dizer que a ordem jurídica foi alterada em si, mas, simplesmente, que as experiências à sua volta se modificaram, como não poderia deixar de ser diante do transcorrer do tempo. Como toda norma há de ser interpretada para que faça sentido - ainda

\footnotetext{
${ }^{286}$ GALINDO (2001, p. 256)

${ }^{287}$ RAMOS (2002, p. 57)

${ }^{288}$ RAMOS (2002, p. 69)

${ }^{289}$ HÄBERLE apud VALE; MENDES (2009)
} 
que a título de mera subsunção do fato à norma - a norma se modifica com o tempo, como explana Häberle:

O Direito Constitucional vive, prima facie, uma problemática temporal. De um lado, a dificuldade de alteração e a conseqüente duração e continuidade, confiabilidade e segurança; de outro, o tempo envolve o agora mesmo, especificamente o Direito Constitucional. É que o processo de reforma constitucional deverá ser feito de forma flexível e a partir de uma interpretação constitucional aberta. A continuidade da Constituição somente será possível se passado e futuro estiverem nela associados. ${ }^{290}$

Completa Pérez Luño: "La juridicidad o antijuridicidad, la licitud o ilicitud, la validez o invalidez de los actos jurídicos son categorías de fronteras móviles y oscilantes que de ningún modo pueden considerarse previas a su definición o tipificación como tales." 291

Assim, analisaremos os seguintes precedentes: o Recurso Extraordinário $\mathrm{n}^{\circ}$ 466.343, o Recurso Extraordinário $\mathrm{n}^{\circ} 349.703$ e o Habeas Corpus $\mathrm{n}^{\circ}$ 87.585, que corroboraram o entendimento que aqui identificaremos, em que foi consubstanciada essa evolução de interpretação. Devemos, contudo, vislumbrar que, a única razão pela qual temos o mínimo de certeza de que esse entendimento será aplicado a novos casos propostos ao Supremo é a edição da Súmula Vinculante $n^{0}$ 25, de 2009, já que a tese foi abraçada pelo tribunal em sede de controle de constitucionalidade difuso - e a Súmula Vinculante é, como vimos, um instrumento para tornar erga omnes as decisões encontradas em controle concreto, e não abstrato. Nela encontramos a seguinte redação: "É ilícita a prisão civil de depositário infiel, qualquer que seja a modalidade do depósito.”, conclusão advinda da aplicação da tese da supralegalidade do tratado internacional conhecido como Pacto de San Jose da Costa Rica.

O que faz com que a doutrina e a jurisprudência se debrucem sobre o tema é justamente a omissão do constituinte em delimitar de forma clara qual seria a hierarquia das normas internacionais em relação a cada tema - pois os direitos humanos, por exemplo, por sua natureza, merecem maior proteção. Cabe ressaltar, ainda, que essa omissão já é tradição na história do constitucionalismo brasileiro, pois nenhuma Constituição até hoje estabeleceu os referidos parâmetros para que se saiba qual norma deve prevalecer em caso de conflito normativo. ${ }^{292} \mathrm{O}$ professor Galindo nos traz a observação de que "Quando estava sendo preparada a Constituição de 1934, tentou-se garantir a superioridade dos tratados em relação

\footnotetext{
${ }^{290}$ HÄBERLE apud VALE; MENDES (2009)

${ }^{291}$ PÉREZ LUÑO (2002, p. 60)

${ }^{292}$ GALINDO (2001, p. 133)
} 
às leis ordinárias federais, tomando como modelo a Constituição da Espanha de 1931."293, mas não se logrou êxito nessa tentativa.

A tese inicialmente adotada pelo Supremo Tribunal Federal era a da legalidade ordinária dos tratados internacionais - até mesmo para aqueles que tratassem de direitos humanos - conforme podemos perceber pelo julgamento do RE 80.004, em 1977, referente a Direito Comercial. Além disso, em razão do caráter legal da norma internacional, qualquer norma interna que lhe fosse posterior poderia revogá-la diante da aplicação do princípio: lex posterior derrogat legi priori. ${ }^{294}$ Também aplicou-se, durante muito tempo, o princípio da especialidade, sem analisar a questão da hierarquia entre as normas em conflito. ${ }^{295}$ Dessa forma, as normas internacionais não possuíam qualquer segurança jurídica dentro do ordenamento brasileiro, podendo ser descumpridas a qualquer tempo.

Aos olhos da Convenção de Viena de 1969, em cujo art. 27 se encontra o disposto: "Uma parte não pode invocar as disposições de seu direito interno para justificar o descumprimento de um tratado. Esta regra não prejudica o artigo 46.”, a interpretação jurisprudencial brasileira não teria qualquer efeito, tendo em vista que o art. 46 trata apenas de vícios de nulidade na promulgação do tratado. ${ }^{296}$ Ao Direito Internacional não parece importar o aspecto cronológico das normas e nem mesmo a sua hierarquia - ainda que fosse uma nova norma constitucional - pois o que esse ramo do Direito exige é o cumprimento das normas acordadas de acordo com a aplicação do princípio pacta sunt servanda. O contraponto é feito por Raquel Lima em: "ainda que a lei anterior tenha sido decorrente de um compromisso internacional firmado pelo país, a criação de uma nova lei pelo Congresso Nacional demonstraria a vontade soberana do povo de alterar a regulação de direitos e conflitos."297 Quando a referida norma trata de direitos humanos, o professor George Galindo adverte: "parece claro que a soberania popular não se opõe à proteção da pessoa humana. E mais, a soberania popular não pode servir de entrave para a efetivação dos Direitos Humanos." 298

Interessante notar, também, a posição do Ministro Leitão de Abreu, no sentido de que a norma internacional não poderia ser revogada por norma interna por possuir "forma própria de revogação, a denúncia, somente podendo ser alterado por outra norma de categoria

\footnotetext{
${ }^{293}$ GALINDO (2001, p. 134)

${ }^{294}$ VALE; MENDES (2009)

${ }^{295}$ GALINDO (2001, p. 140)

${ }^{296}$ GALINDO (2001, p. 164)

${ }^{297}$ LIMA (2010, p. 31)

${ }^{298}$ GALINDO (2001, p. 233)
} 
igual ou superior, internacional, e jamais pela inferior, interna ou nacional" ${ }^{\text {299 }}$, propugnando pelo simples afastamento do tratado, que poderia voltar a incidir caso a lei fosse revogada.

Em 1995, já sob a égide da nova Constituição, o tema voltou a ser discutido no $\mathrm{HC} \mathrm{n}^{\mathrm{o}}$ 72.131, que tratava da mesma matéria de que tratam os precedentes que escolhemos para analisar a questão: a possibilidade de prisão do depositário infiel diante do art. $7^{\circ}$, item 7 , do Pacto de San José da Costa Rica - que dispõe que "ninguém deve ser detido por dívida", a não ser em virtude do inadimplemento de obrigação alimentar. O que foi decidido, à época, foi que a norma internacional, por ser norma geral, não afastaria a aplicação do Decreto-Lei n. 911/69, que regulamenta especificamente esse tipo de prisão ao equiparar o devedor fiduciante ao depositário infiel e foi recepcionado pela nova Constituição. ${ }^{300}$

Em 1997, o entendimento acima foi mantido em sede de controle de constitucionalidade abstrato, na ADI n ${ }^{\circ}$ 1.480. A referida ação foi importante, no entanto, por esclarecer questões acerca das quais a doutrina se debatia. Primeiramente, ficou claro que o entendimento do Supremo equiparava as normas internacionais às leis ordinárias, e não a leis complementares, como defendiam alguns, admitindo, assim, a paridade normativa sem hierarquia de qualquer espécie. ${ }^{301}$ Outra definição relevante, como se pode ver por meio da ementa abaixo transcrita, foi a de que, tanto em sede de controle difuso, quanto em sede de controle concentrado - esse já previsto na competência constitucional do Supremo -, as normas internacionais estariam sujeitas a controle. Cabe ainda lembrar que o controle é feito a partir dos Decretos - Legislativo e Executivo - ainda que só faça sentido falar em controle do Decreto Legislativo se estivermos tratando do controle de constitucionalidade preventivo, uma vez que não é por meio desse Decreto que o tratado é inserido no ordenamento. ${ }^{302}$

AÇÃO DIRETA DE INCONSTITUCIONALIDADE - CONVENÇÃO N. 158/OIT (...) SUBORDINAÇÃO NORMATIVA DOS TRATADOS INTERNACIONAIS À CONSTITUIÇÃO DA REPÚBLICA. - No sistema jurídico brasileiro, os tratados ou convenções internacionais estão hierarquicamente subordinados à autoridade normativa da Constituição da República. Em consequiência, nenhum valor jurídico terão os tratados internacionais, que, incorporados ao sistema de direito positivo interno, transgredirem, formal ou materialmente, o texto da Carta Política. O exercício do treaty-making power, pelo Estado brasileiro - não obstante o polêmico art. 46 da Convenção de Viena sobre o Direito dos Tratados (ainda em curso de tramitação perante o Congresso Nacional) -, está sujeito à necessária observância das limitações jurídicas impostas pelo texto constitucional. CONTROLE DE CONSTITUCIONALIDADE DE TRATADOS INTERNACIONAIS NO SISTEMA JURÍDICO

\footnotetext{
${ }^{299}$ ABREU apud GALINDO (2001, p. 139)

${ }^{300}$ VALE; MENDES (2009)

${ }^{301}$ LIMA (2010, p. 31-32)

302 GALINDO (2001, p. 171)
} 
BRASILEIRO - O Poder Judiciário - fundado na supremacia da Constituição da República - dispõe de competência, para, quer em sede de fiscalização abstrata, quer no âmbito do controle difuso, efetuar o exame de constitucionalidade dos tratados ou convenções internacionais já incorporados ao sistema de direito positivo interno. Doutrina e Jurisprudência. PARIDADE NORMATIVA ENTRE ATOS INTERNACIONAIS E NORMAS INFRACONSTITUCIONAIS DE DIREITO INTERNO - Os tratados ou convenções internacionais, uma vez regularmente incorporados ao direito interno, situam-se, no sistema jurídico brasileiro, nos mesmos planos de validade, de eficácia e de autoridade em que se posicionam as leis ordinárias, havendo, em conseqüência, entre estas e os atos de direito internacional público, mera relação de paridade normativa. (...) O primado da Constituição, no sistema jurídico brasileiro, é oponível ao princípio pacta sunt servanda, inexistindo, por isso mesmo, no direito positivo nacional, o problema da concorrência entre tratados internacionais e a Lei Fundamental da República, cuja suprema autoridade normativa deverá sempre prevalecer sobre os atos de direito internacional público. (...)

(ADI 1480 MC, Relator(a): Min. CELSO DE MELLO, Tribunal Pleno, julgado em 04/09/1997) (grifos aditados)

Como podemos perceber, o julgado faz referência à Convenção de Viena, mas não se preocupa em infringir um de seus artigos ao decidir, já que o tratado ainda não havia sido aprovado pelo Congresso - isto é, ainda não estava em vigor, pois o Brasil não havia completado seu consentimento em cumprir o tratado: situação essa que só se encerrou em 14 de dezembro de 2009, com a promulgação do Decreto 7.030.

Por outro lado, mesmo ainda identificando a norma internacional como se fosse lei ordinária, surgiram posicionamentos, inclusive de Ministros do Supremo, defendendo a suspensão da norma que regula a prisão do depositário infiel, já que o tratado lhe seria posterior e, então, ela teria sido revogada. Seria necessária uma nova lei para revogar, dessa vez, o tratado. ${ }^{303}$

Nessa esteira de acontecimentos, os julgamentos do HC n. 87.585 e dos RE's n. 466.343 e n. 349.703 trouxeram a mutação da interpretação jurisprudencial do Supremo Tribunal. A Procuradoria Geral da República emitiu parecer em que identificava a prisão civil como instrumento de coerção desproporcional e sem utilidade ao processo, além de inviabilizar a obtenção de meios para o pagamento do débito. ${ }^{304}$ Assim, os Ministros passaram a analisar qual deveria ser o tratamento dado ao conflito entre normas de direito interno e de direito internacional no tocante à matéria de direitos humanos em face de sua crescente internalização. ${ }^{305}$

\footnotetext{
${ }^{303}$ GALINDO (2001, p. 209)

${ }^{304} \mathrm{HC}$ n. 87.585-8/TO (2008, p. 238 et seq.).

${ }^{305} \operatorname{LIMA}(2010$, p. 33)
} 
No RE 466.343, o voto que conduziu o julgamento foi o de Gilmar Mendes, embora a relatoria fosse do Ministro Cezar Peluso. Foram vislumbradas, ali, quatro vertentes doutrinárias possíveis acerca do status hierárquico das normas internacionais de direitos humanos: a equiparação à lei ordinária, que já era o entendimento adotado pelo Supremo para todas as normas internacionais; a supraconstitucionalidade dos tratados e convenções; a equiparação desses diplomas internacionais às normas constitucionais; e a interpretação que adotaria a teoria da supralegaligade dessas mesmas normas - tendo essa última prevalecido pelas razões a seguir dispostas. ${ }^{306}$

A tese da supraconstitucionalidade foi rejeitada por se imaginar que, se ela fosse adotada, a soberania estatal estaria em perigo, sujeita a uma produção normativa externa e que não poderia sequer ser controlada pela análise da constitucionalidade da norma, uma vez que essa seria superior à própria Constituição. ${ }^{307}$

No tocante à teoria da constitucionalidade, os Ministros fizeram uma interpretação buscando a vontade do constituinte derivado e, em uma leitura a contrario sensu, chegaram à conclusão de que, se a Emenda $n^{o} 45 / 04$ trouxe o disposto no $\S 3^{\circ}$, que equipara as normas internacionais de direitos humanos às normas constitucionais mediante a aprovação por quórum igual ao de uma Emenda Constitucional, seria porque, aquelas que não fossem submetidas a esse quórum não deveriam ser constitucionais. ${ }^{308}$

Ainda contra essa possibilidade, o Ministro Gilmar Mendes tece o seguinte comentário, mostrando que o aumento exacerbado de normas constitucionais levaria, além da atomização das normas constitucionais, a não proteção efetiva dos direitos humanos, uma vez que haveria o problema da qualificação das normas em protetoras de direitos humanos ou não:

Nós temos uma Constituição já por si só extensa. Se agora formos afirmar que todos os tratados de direitos humanos - e, aí, certamente vamos ter uma disputa hermenêutica para saber quais são esses tratados de direitos humanos - têm também hierarquia constitucional originária, certamente estamos nos embrenhando por um caminho que, talvez, em termos de insegurança jurídica, a vista já não mais alcança. ${ }^{309}$

Assim, alterou-se o entendimento jurisprudencial que adotava a teoria da ordinariedade, ou da legalidade, para a adoção da teoria da supralegalidade, não impedindo,

\footnotetext{
${ }^{306}$ RE n. 466.343/SP (2006, p. 3-4) Analisaremos mais detidamente os argumentos que foram utilizados durante os julgamentos em estudo para a aplicação ou não dessas teorias, pois, o histórico, a aplicabilidade segundo o Direito Comparado e as consequências da aplicação de cada uma dessas teorias será matéria tratada no capítulo seguinte.

${ }^{307}$ RE n. 466.343/SP (2006, p. 5) Os Ministros parecem ter se esquecido de que, ainda que fosse deferido o caráter supraconstitucional aos tratados de direitos humanos, eles somente entrariam em vigor no Brasil após todo o trâmite previsto constitucionalmente no tocante a aprovação, ratificação e promulgação.

308 LIMA (2010, p. 34)

${ }^{309}$ HC n. 87.585-8/TO (2008, p. 345)
} 
contudo, que qualquer tratado de direitos humanos, independente de já ter tido sua promulgação, passasse pelo quórum do $\S 3^{\circ}$, para adquirir status constitucional. Em síntese:

Nesse sentido, concluiu o Supremo Tribunal Federal que, diante da supremacia da Constituição sobre os atos normativos internacionais, a previsão constitucional da prisão civil do depositário infiel (art. $5^{\circ}$, inciso LXVII) não foi revogada pelo ato de adesão do Brasil ao Pacto Internacional dos Direitos Civis e Políticos (art. 11) e à Convenção Americana sobre Direitos Humanos - Pacto de San José da Costa Rica (art. $\left.7^{\circ}, 7\right)$, mas deixou de ter aplicabilidade diante do efeito paralisante desses tratados em relação à legislação infraconstitucional que disciplina a matéria, incluídos o artigo 1.287 do Código Civil de 1916 e o Decreto-Lei 911, de $1^{\circ}$ de outubro de 1969.

Tendo em vista o caráter supralegal desses diplomas normativos internacionais, a legislação infraconstitucional posterior que com eles seja conflitante também tem sua eficácia paralisada. É o que ocorre, por exemplo, com o artigo 652 do Novo Código Civil (Lei 10.406/2002), que reproduz disposição idêntica ao artigo 1.287 do Código Civil de 1916.

Enfim, desde a adesão do Brasil, no ano de 1992, ao Pacto Internacional dos Direitos Civis e Políticos (art. 11) e à Convenção Americana sobre Direitos Humanos - Pacto de San José da Costa Rica (art. $\left.7^{\circ}, 7\right)$, não há base legal para aplicação da parte final do artigo $5^{\circ}$, inciso LXVII, da Constituição, ou seja, para a prisão civil do depositário infiel. ${ }^{310}$

Na redação do voto condutor do julgamento do RE no 466.343, Gilmar Mendes consubstancia, ainda, que a prisão do depositário infiel contrariava a Constituição de 1988 - e não apenas as normas infraconstitucionais que regulamentavam a prisão - antes mesmo da promulgação da Convenção Americana de Direitos Humanos, pois ofendia o princípio da proporcionalidade, como já havia antecipado o parecer do Procurador Geral da República, violando a proibição do excesso e ofendendo também a reserva legal proporcional. ${ }^{311}$ Assim, reconhece-se que "A Constituição atribui ao legislador a tarefa de dar conformação legal à figura do depósito, mas proíbe-o de desfigurar ou redesenhar esse instituto em termos demasiado restritivos para o depositário." 312 , isto é, privando-o de sua liberdade.

Por outro lado, embora tenha adotado a teoria da supralegalidade das normas internacionais de direitos humanos - e nisso enxergamos uma evolução interpretativa -, o Supremo permanece a fazer referências ao princípio da supremacia da Constituição e tratar como uma realidade absoluta, insuscetível de relativização, a soberania estatal. ${ }^{313}$ Ora, a soberania do Estado é exercida no momento em que ele escolhe aderir ou não a determinada

\footnotetext{
${ }^{310}$ VALE; MENDES (2009)

311 RE n. 466.343/SP (2006, p. 30) Em razão dessa interpretação, a redação da Súmula Vinculante deveria considerar a referida prisão como inconstitucional, e não meramente ilícita.

${ }^{312}$ RE n. 466.343/SP (2006, p. 53)

${ }^{313}$ LIMA (2010, p. 36-37)
} 
norma internacional. Muito mais salutar seria ceder, como sugerem André do Vale e Gilmar Mendes:

Deixe-se acentuado, por fim, que a evolução jurisprudencial sempre foi uma marca de qualquer jurisdição de perfil constitucional. A afirmação da mutação constitucional não implica o reconhecimento, por parte da corte, de erro ou equívoco interpretativo do texto constitucional em julgados pretéritos. Ela reconhece e reafirma, ao contrário, a necessidade da contínua e paulatina adaptação dos sentidos possíveis da letra da Constituição aos câmbios observados numa sociedade que, como a atual, está marcada pela complexidade e pelo pluralismo. ${ }^{314}$

Além disso, o Supremo somente adota a teoria da supralegalidade quando se trata de direitos humanos - que, de fato, exigem tal proteção, mas também poderia ser estendida aos demais tratados -, permanecendo a teoria da legalidade das normas internacionais para aquelas que versam sobre outras matérias, o que pode ser um problema para o cumprimento das normas internacionais, como será visto no capítulo a seguir. 


\section{CAPÍTULO 3 - A TEORIA DA SUPRALEGALIDADE DAS NORMAS INTERNACIONAIS}

O conceito de soberania, em que tanto se sustenta o Supremo Tribunal Federal para refutar a aplicação de normas internacionais, já não pode ser lido em seu contexto clássico, quando, pelo momento histórico, eram atribuídas ao soberano características metafísicas que justificariam todas as suas ações, ${ }^{315}$ conforme vimos na justificativa de Hobbes para a formação do Estado. Bobbio já nos adverte de que esse conceito nada mais é do que uma ilusão no mundo contemporâneo.

A ilusão jurídico-institucional do século XIX consistia em acreditar que o
sistema político fosse auto-suficiente, e portanto gozasse de uma certa
independência do sistema social global, ou que fosse ele próprio o sistema
dominante, e que portanto bastasse buscar remédios adequados ao controle
do sistema político para controlar o sistema de poder da sociedade inteira. ${ }^{316}$,

Não se pretende, de forma alguma, ir contra a existência do Estado. Tratamos, porém, da questão da soberania, por acreditar que a sua exacerbação pode levar a um movimento contrário ao Estado Cooperativo. Como explana Häberle, a soberania popular é um dos elementos do Estado Constitucional, a qual, no entanto, não pode ser entendida como “competencia para la arbitrariedad ni como magnitud mística por en cima de los ciudadanos, sino como fórmula que caracteriza la unión renovada constantemente en la voluntad y en la responsabilidad pública."317

Desse modo, é completamente natural que a Constituição brasileira possua, dentre seus fundamentos e princípios, categorias aparentemente contraditórias entre si, como a soberania e a integração visando à formação de uma comunidade de nações, uma vez que a soberania possui um significado diverso daquele clássico. Um exemplo disso seria a previsão feita pela própria Constituição de submissão a tribunal penal internacional, sem que isso seja considerado como uma ofensa à soberania.

Feitas essas considerações, podemos começar a desenvolver o presente capítulo, que abarcará questões relacionadas à teoria da supralegalidade das normas internacionais e às teorias que lhe são colocadas como opções, a depender da adoção da perspectiva monista ou dualista, bem como as consequências advindas dessa escolha.

\footnotetext{
${ }^{315}$ BOSON (1996, p. 141)

${ }^{316}$ BOBBIO (2000, p. 258-259)

${ }^{317}$ HÄBERLE (2003, p. 1)
} 


\subsection{O SIGNIFICADO DA TEORIA DA SUPRALEGALIDADE E SUA APLICAÇÃO NO ESTRANGEIRO}

Conforme mencionamos brevemente ao tratar da jurisprudência do Supremo Tribunal Federal que adotou a teoria da supralegalidade das normas internacionais de direitos humanos, essa teoria consiste em instrumento para dirimir eventuais conflitos entre normas internas e normas internacionais, enxergando os tratados entre sujeitos de Direito Internacional como superiores às leis internas, mas inferiores hierarquicamente às Constituições estatais. ${ }^{318}$

De início analisaremos as teorias acerca da relação entre Direito Interno e Direito Internacional, quais sejam: a teoria monista com prevalência do Direito Interno, a teoria dualista e a teoria monista com prevalência do Direito Internacional. Esse estudo se faz indispensável ao desenvolvimento do trabalho, uma vez que, embora dificilmente se aplique uma teoria pura, sem influências das outras, são essas teorias que legitimarão os discursos e as práticas dos sujeitos de Direito Internacional - Estados e organizações, principalmente. ${ }^{319}$

Os maiores expoentes da primeira teoria ${ }^{320}$ - monista com prevalência do Direito Interno - são Spinoza e Hegel. Em excesso, a prevalência do Direito Interno levaria à negação do internacionalismo, pois se baseia na ausência de uma autoridade superior ao Estado, levando a crer que o mundo viveria em estado de natureza na ordem internacional. $\mathrm{O}$ Direito Internacional serviria apenas para legitimar a atuação voluntarista do Estado, considerado como único sujeito de direito, atrelado às ideias de soberania e supremacia - o Estado tem o "direito" de violar tratados, pois nada limita sua vontade. Assim, a obrigatoriedade de determinadas condutas no plano internacional só se dá quando prevista pelo Direito Interno. "Mesmo quando há uma ruptura constitucional, os tratados continuam a vigorar, provando que as Constituições não podem de maneira alguma fundamentar o Direito Internacional”321 e nesse sentido se encontra a crítica mais veemente ao monismo com prevalência do Direito Interno.

Como já explanado, a soberania está, hoje, relativizada em favor do Estado Cooperativo, embora não possa ser negada. A Constituição chilena de 1980, após a Reforma de 1989, corrobora, em seu art. $5^{\circ}$, esse entendimento, expressando que sua soberania tem

\footnotetext{
${ }^{318}$ RE n. 466.343/SP (2006, p. 21)

${ }^{319}$ GALINDO (2001, p. 9)

${ }^{320}$ GALINDO (2001, p. 11 et seq.)

${ }^{321}$ GALINDO (2001, p. 16)
} 
como limites os direitos essenciais à pessoa - devendo o Estado garanti-los, inclusive aqueles constantes de tratados internacionais. ${ }^{322}$

As teorias dualistas espanholas, também conhecidas como dualismo moderado por fazer concessões ao monismo com prevalência do Direito Internacional, alegam que haveria dois sistemas jurídicos distintos - um Interno e outro Internacional - mas ambos submetidos ao Direito Natural. ${ }^{323}$ A teoria surge no final do século XIX, com Triepel, que a baseia em três diferenças fundamentais entre os sistemas jurídicos: a) no ordenamento interno o homem também seria sujeito de direitos, enquanto que, em âmbito internacional, apenas os Estados seriam; b) a fonte do Direito Interno seria a vontade do Estado, enquanto que, no plano internacional, a fonte seria a vontade coletiva, tendo em vista, por exemplo, sua natureza consuetudinária; c) a ordem jurídica interna encontra respaldo na subordinação, mas, a internacional se baseia na cooperação. Aplicando-se essa teoria, para que uma norma de Direito Internacional seja aplicada pelo Estado, ela deve ser "incorporada", uma vez que originalmente ela pertencia a outro sistema jurídico independente - o tratado seria como um convite ao Estado a um ato particular de vontade, diferente do desenvolvimento internacional. $^{324}$

Essa teoria, quando adotada por Anzilotti, admitiu "adoção da idéia da existência de uma norma fundamental no Direito Internacional. Esta regra seria o princípio pacta sunt servanda” ${ }^{325}$ Algumas das críticas são: as normas consuetudinárias internacionais são aplicadas pelos tribunais internos sem incorporação; Kelsen alega que a cooperação, na verdade, seria uma submissão a uma terceira ordem; a teoria em questão trata o Direito Internacional como se fosse todo de caráter privatístico. ${ }^{326}$.

O monismo com prevalência do Direito Internacional surge, então, como resposta ao dualismo - de maneira mais radical e lógica, iniciou-se por Kelsen a fim de emprestar obrigatoriedade ao Direito Internacional, declarando nula toda norma interna que entrasse em conflito com normas internacionais. "Para Kelsen, neste caso não há qualquer conflito entre a norma inferior e a norma superior, mas apenas a anulabilidade da norma inferior ou a punibilidade de um órgão responsável." ${ }^{327}$ Foi seguido por Verdross e Kunz, mas de modo a flexibilizá-lo. "É famosa a posição de Verdross quanto à questão das Constituições que estabelecem que as regras universalmente reconhecidas do Direito Internacional valem

\footnotetext{
${ }^{322}$ CONSTITUIÇÃO CHILENA DE 1980 apud GALINDO (2001, p. 275)

${ }^{323}$ GALINDO (2001, p. 18)

${ }^{324}$ MELLO (2001, p. 109-110)

${ }^{325}$ GALINDO (2001, p. 37)

${ }^{326}$ MELLO (2001, p. 110-111)

${ }^{327}$ GALINDO (2001, p. 33)
} 
como parte integrante de determinado Direito." ${ }^{328}$ Outra vertente dessa teoria foi seguida por Georges Scelle, que a ela chegou a partir de bases sociológicas do federalismo. ${ }^{329}$ Lauterpacht foi outro expoente da teoria e "sua luta contra as influências perniciosas do positivismo no Direito Internacional e sua insistência no reconhecimento da personalidade internacional dos indivíduos talvez sejam os mais conhecidos. ${ }^{, 330}$ A principal crítica é que, historicamente, o Direito Internacional surgiu depois dos Estados e de seus ordenamentos e por isso não deveria prevalecer.

Como foi estabelecido antes de iniciar a análise das teorias, é difícil encontrar a aplicação pura de uma delas, sendo mais comum as teorias mistas ou moderadas. Surgem, assim, novas teorias chamadas conciliadoras, sendo, algumas dessas, interessantes para o estudo do Direito Internacional, como se pode ver pelo transcrito a seguir:

Erich Kaufman fala em "ideia de Direito", que por ser a mesma nas duas ordens jurídicas, as uniria; acrescenta que existem princípios que pertenceriam a uma ordem superior, que estão unidos à ideia de Direito, que se impõem onde o direito seja aplicado. Estes princípios seriam do Direito Natural. ${ }^{331}$

A teoria supra citada vai ao encontro da jurisprudência dos tribunais internacionais, uma vez que eles costumam dar primazia ao Direito Internacional, como era de se esperar. Além disso, a unidade de Direito é extremamente conveniente dentro da perspectiva do Estado Cooperativo, pois traz uma maior interação entre os agentes normativos e evita, assim, a possibilidade de conflito entre suas normas. ${ }^{332}$

Kaufman bem observa que é "o mesmo Estado que possui uma vida interior e uma vida exterior"; ele "é o ponto de junção entre as duas ordens". Dentro deste raciocínio, um Estado pode incorrer em responsabilidade internacional mesmo quando a violação do DI é cometida por sua lei básica, a Constituição. Neste sentido encontramos na jurisprudência internacional a decisão da comissão arbitral franco-mexicana, no caso George Pinson. ${ }^{333}$

Assim, retomamos a importância de que os Estados cumpram as normas a que estão vinculados, independente da teoria adotada em suas Constituições, já que o pacta sunt servanda é um princípio de aplicação global e que, caso descumprido, importará responsabilização do Estado, juntamente com possíveis sanções. É interessante perceber que:

O conflito somente se dá [entre tratado e lei ou entre Constituição e tratado] em caso de tratados self-executing e disposições de Direito Interno. Ou seja,

\footnotetext{
${ }^{328}$ GALINDO (2001, p. 41)

${ }^{329}$ GALINDO (2001, p. 31 et seq.)

${ }^{330}$ GALINDO (2001, p. 45)

${ }^{331}$ MELLO (2001, p. 113)

332 GALINDO (2001, p. 159)

${ }^{333}$ MELLO (2001, p. 115)
} 
os tratados que podem necessariamente ser invocados no Direito Interno sem a intermediação de qualquer lei interna. No caso de tratados nonselfexecuting, onde se estabelece a obrigação de o Estado legislar para se conformar à obrigação internacionalmente pactuada, haverá somente possibilidade de conflito entre normas internas. Neste último caso, ressaltese, a obrigação internacional permanece. Mudará apenas o meio de cumprila. Seguindo a linha de Buergenthal, é matéria de Direito Interno disciplinar que tratados são self-executing ou não. Em sistemas que adotam o dualismo, como é, em princípio, o caso do Reino Unido, por exemplo, esta distinção é inócua, uma vez que os tratados são necessariamente transformados em Direito Interno, por meio de instrumentos legislativos, a fim de valer internamente. ${ }^{334}$

A partir de então começamos a analisar quais são os Estados que adotaram a teoria da supralegalidade e de que modo essa decisão foi concretizada em seus ordenamentos. A Constituição búlgara, por exemplo, adota a supralegalidade dos tratados aliada, ainda, à ideia de controle de constitucionalidade preventivo, o que seria ideal quando colocado em prática. ${ }^{335}$ Mais próximo a nós, temos os países do MERCOSUL, como Argentina e Paraguai, os quais, em nome da interação gerada por esse bloco econômico, vêm adotando posturas no sentido de reconhecer a superioridade dos tratados em relação às leis. ${ }^{336}$ A Argentina, principalmente, após sua reforma constitucional em 1994, reconheceu o que seus tribunais já vinham aplicando: consagrou a estatura de norma constitucional aos tratados de direitos humanos, a fim de fornecer-lhes maior proteção, passando, então a adotar um monismo com prevalência do Direito Internacional. ${ }^{337}$ Com isso, podemos concluir que:

En la medida en que, desde la perspectiva internacional, la cooperación entre los Estados ocupe el lugar de la mera coordinación y del simple ordenamiento de la coexistencia pacífica (es decir, de la delimitación de los ámbitos de la soberanía nacional), en el campo del derecho constitucional nacional pueden advertirse tendencias que apuntan hacia un debilitamiento de la distinción estricta entre lo interno y lo externo a favor de una apertura hacia el exterior. ${ }^{338}$

A supralegalidade não é a única forma de se conseguir a cooperação entre os Estados, como veremos a seguir. No entanto, é considerada por muitos - inclusive tendo sido a escolhida pelo Judiciário brasileiro -, quando se trata de dar proteção e efetividade aos tratados de direitos humanos, a melhor opção, por não se correr o risco de ofender à malfadada soberania estatal.

Não há dúvida de que, no Estado constitucional cooperativo, é mais consistente a interpretação que atribui a característica de supralegalidade aos

\footnotetext{
${ }^{334}$ GALINDO (2001, p. 136)

${ }^{335}$ GALINDO (2001, p. 236)

${ }^{336}$ GALINDO (2001, p. 154)

${ }^{337}$ GALINDO (2001, p. 276 et seq.)

${ }^{338}$ HÄBERLE (2003, p. 73)
} 
tratados e convenções de direitos humanos. Essa tese pugna pelo argumento de que os tratados sobre direitos humanos seriam infraconstitucionais, porém, diante de seu caráter especial em relação aos demais atos normativos internacionais, também seriam dotados de um atributo de supralegalidade.

Em outros termos, os tratados sobre direitos humanos não podem afrontar a supremacia da Constituição, mas têm lugar especial reservado no ordenamento jurídico. Equipará-los à legislação ordinária significa subestimar o seu valor especial no contexto do sistema de proteção dos direitos da pessoa humana.

Assim, diante do inequívoco caráter especial dos tratados internacionais que cuidam da proteção dos direitos humanos, entende-se que a sua internalização no ordenamento jurídico, por meio do procedimento de ratificação previsto na Constituição, tem o condão de paralisar a eficácia jurídica de toda e qualquer disciplina normativa infraconstitucional com ela conflitante. ${ }^{339}$

\subsection{AS TEORIAS OPTATIVAS À TEORIA DA SUPRALEGALIDADE}

As Constituições, segundo Antonio Cassese, podem se referir à matéria dos tratados de quatro maneiras: omissiva, sem nada estabelecer acerca de hierarquia normativa; estabelecendo que obrigações convencionais devem ser obedecidas por todos, mas não considerando os tratados como superiores às leis ordinárias; determinando que tratados são superiores às leis internas - supralegalidade; e trazendo a possibilidade de tratados modificarem normas constitucionais. ${ }^{340}$ O Brasil parece ter adotado uma espécie de teoria mista - ainda que vinculada ao dualismo, pois claramente aplica a incorporação das normas internacionais ao sistema brasileiro ${ }^{341}$ - a partir da mutação de interpretação do Supremo que já estudamos: a teoria da supralegalidade para os tratados de direitos humanos que não atendessem ao quórum de aprovação do $\S 3^{\text {o }}$; a constitucionalidade dessas mesmas normas quando atendido o quórum, que, na visão de Celso Albuquerque de Mello, poderia se estender às demais matérias; e, ainda, a legalidade dos tratados internacionais que versem sobre outras matérias - tudo isso em decorrência da omissão do constituinte.

A única regra expressa no ordenamento brasileiro no tocante aos tratados internacionais que não sejam de direitos humanos se encontra no art. 98 do Código Tributário Nacional, o qual já estabelecia a supralegalidade das normas internacionais, mas, obviamente, apenas em matéria tributária. Parte da doutrina considera que o dispositivo da lei não deve ser aplicado, uma vez que o constituinte se omitiu, e isso equivaleria à equiparação das normas

\footnotetext{
${ }^{339}$ VALE; MENDES (2009)

${ }^{340}$ GALINDO (2001, p. 134)

${ }^{341}$ MELLO (2001, p. 119)
} 
internacionais à legislação ordinária. ${ }^{342}$ Estranho seria reconhecer esse tratamento diferenciado a normas tributárias, e não a direitos humanos, e nisso a decisão do Supremo acertou. $^{343}$

Deve-se sempre propugnar pela interpretação que evite antinomias entre a norma interna e a internacional e, nesse sentido, o Brasil permite interpretações desse gênero pelo disposto no art. $4^{\circ}$ de sua Constituição. ${ }^{344}$ Quando, no entanto, o confronto for inevitável, deve ser mantida a validade da norma internacional, pois, após o Estado ter acordado determinado tratado, não é de bom grado que ele o descumpra alegando a sua inconstitucionalidade - essa sequer evita a responsabilização internacional. Uma alternativa que não chega ao mérito da hierarquia normativa é a análise a partir da competência, que considera os órgãos estatais incompetentes para modificar unilateralmente compromissos internacionais em vigor. ${ }^{345}$ Para isso, também é de suma importância o controle de constitucionalidade preventivo, não reparador, assim como prevê o art. 241 da Constituição colombiana. $^{346}$

Quando esse não se fizer possível, o Estado deve buscar alternativas que não a declaração de nulidade - como o simples afastamento da norma - tendo em vista que, conforme defendido pelo Ministro Leitão de Abreu, no RE 80.004, seria impossível que a norma interna revogasse ou anulasse o tratado, pois são normas de sistemas jurídicos distintos - para os dualistas - e, ainda que assim não se considere, a norma deixará de ter aplicabilidade apenas em um país, não sendo considerada nula para os demais. ${ }^{347}$

Ainda, sob um ponto de vista prático, em determinados casos, o tratado prevalece em relação à lei sem a necessidade de uma declaração específica neste sentido. Assim, diversos recursos interpretativos podem ser aplicados, como a presunção iuris tantum de que o Legislador permite a aplicação das disposições preexistentes do tratado; a aplicação do princípio da especialidade; a interpretação de conformidade da lei com o tratado; a aplicação da idéia de que o tratado, como fruto do acordo entre sujeitos de Direito Internacional, prevaleceria sobre disposições como a lei, emanada por apenas uma das partes. Também o uso de uma interpretação constitucional "amiga" do Direito Internacional. Ainda restaria a possibilidade de considerar o tratado como non-self-executing, situação que, como dito, não estaria a nível de conflito entre norma de Direito Internacional e norma de Direito Interno. ${ }^{348}$

342 GALINDO (2001, p. 141) Entendemos, todavia, que, se o constituinte se omitiu, a legislação infraconstitucional está autorizada a adotar a hierarquia que entender própria à matéria de que trata, uma vez que o que não é proibido é permitido.

${ }^{343}$ RE n. 466.343/SP (2006, p. 23)

${ }^{344}$ GALINDO (2001, p. 175)

${ }^{345}$ GALINDO (2001, p. 136)

${ }^{346}$ GALINDO (2001, p. 235)

${ }^{347}$ GALINDO (2001, p. 174)

${ }^{348}$ GALINDO (2001, p. 137) 
Nesse sentido segue a crítica do professor George Galindo à antiga jurisprudência do Supremo, filiada à teoria da legalidade das normas internacionais. $\mathrm{O}$ referido autor já antevia a teoria da supralegalidade como melhor alternativa - mais abrangente do que o Supremo, no entanto, pois ampliou a aplicação da teoria a todas as matérias, e a relativizou quando tratasse de direitos humanos, para que se pudesse garantir à vítima o melhor tratamento normativo.

Teria sido possível ao Supremo optar por diversas saídas para não proclamar a decisão equiparando tratado e lei. A primeira delas seria admitir a superioridade da norma internacional. A segunda seria recorrer a inúmeros métodos interpretativos que buscam evitar o conflito. A "supremacia do Poder Judiciário" não ficaria diminuída com tal conduta. Ao contrário, aumentaria a sua credibilidade. ${ }^{349}$

O tratamento hierárquico dado às normas internacionais no Direito nacional em muito depende da confiança nas instituições internacionais e é interessante ao Direito Internacional que suas normas possuam força nos ordenamentos internos, pois isso facilita a sua execução e garante o seu cumprimento. Por outro lado, há que se considerar que uma imposição do grau hierárquico superior por parte do Direito Internacional não seria agradável aos Estados, podendo ocasionar até mesmo a restrição em se aceitar novos tratados. ${ }^{350}$ Vedel complementa a crítica à constitucionalidade alegando que "se qualquer tratado que limitasse a competência do Estado tivesse que ser por lei constitucional, o Estado acabaria sem poder concluir tratados". 351

Portanto, o cumprimento dos tratados passa a não ser somente dirigido aos órgãos políticos. Também demanda a ação de inúmeras autoridades administrativas e a cooperação dos tribunais para aplicar as disposições convencionais nos casos surgidos entre particulares. (...) a possibilidade maior de conflitos entre tratados internacionais e Constituições deve-se a um aumento quantitativo e qualitativo do Direito Internacional. (...) característica do constitucionalismo das décadas de setenta e oitenta de preferir Constituições analíticas e dirigentes. Embora este fenômeno mostre sinais de esgotamento, Constituições desta natureza tornam-se muito mais propícias ao conflito com disposições convencionais, tanto pelo tipo como pela quantidade de matérias versadas. ${ }^{352}$

Sendo assim, como ao Direito Internacional suas normas são válidas de qualquer maneira, e ele não impõe um grau hierárquico normativo aos Estados, cabe a cada Constituição estabelecer qual modelo seguirá: o da supraconstitucionalidade, o da

\footnotetext{
${ }^{349}$ GALINDO (2001, p. 152)

${ }^{350}$ GALINDO (2001, p. 155)

${ }^{351}$ VEDEL apud MELLO (2001, p. 120)

${ }^{352}$ GALINDO (2001, p. 163)
} 
constitucionalidade, o da supralegalidade ou o da legalidade das normas internacionais. Somente as Constituições poderiam sobrepor outras normas ao seu próprio texto, como escolheu a Holanda. ${ }^{353}$

A Holanda adota que a ordem jurídica comunitária está acima de sua Constituição (...). A Constituição holandesa é expressa no sentido de que os tratados e, até mesmo, as decisões obrigatórias das organizações internacionais não podem ser revogadas por legislação interna e revoga a esta. A norma internacional tem valor supraconstitucional. Existe nesse sentido o controle da convencionalidade e o D. Constitucional tem que ser conforme ao DIP. Na Suíça o Tribunal Federal "opera no controle de convencionalidade das leis nacionais", isto é, se estas não violam convenções internacionais. Os tribunais não alegam inclusive que o tratado não é "self-executing", porque isto faria com que o tratado não fosse aplicado. ${ }^{354}$

A Grã-Bretanha e os Estados Unidos, por sua vez, equiparam as normas de Direito Internacional às nacionais, mostrando-se em posição retrógrada semelhante ao antigo entendimento do Supremo, segundo o qual um tratado pode ser revogado por norma interna que lhe seja posterior. ${ }^{355}$ Por outro lado, é de se notar que, quanto mais elevado for o grau hierárquico dado à norma, maior deve ser o seu conteúdo democrático, para que o Direito Internacional não sirva à legitimação de regimes ditatoriais.

Primeiramente, determinadas Constituições concedem pouca participação democrática na processualística dos tratados, por exemplo, não concedendo nenhum papel formal ao Legislativo - como é o caso do Reino Unido -, ou permitindo que o controle da política externa seja feito por apenas um pequeno grupo. Neste caso, o papel do Parlamento no ato de transformação é imprescindível. Se aos tratados é concedida uma estatura hierárquica superior às leis, este problema se torna ainda mais grave. ${ }^{356}$

Surgem, então, diversas alternativas para o tratamento do relacionamento entre normas internacionais e normas internas. A Constituição austríaca, por exemplo, a fim de evitar a declaração de nulidade de um tratado, prevê em seu art. 140A, que o Tribunal Constitucional, ao perceber a antinomia entre as normas, prorrogará a aplicação do tratado por, no máximo, um ou dois anos, a depender da espécie do tratado, como um tipo de transição, para que a norma não deixe de ser aplicada de maneira abrupta. ${ }^{357}$

Outra alternativa seria a já analisada aplicação dos princípios da norma mais favorável à vítima, da proibição ao retrocesso e da aplicação da lógica da adição, não da supressão, quando falarmos em tratados de direitos humanos, conforme já expressos em

\footnotetext{
${ }^{353}$ GALINDO (2001, p. 158)

${ }^{354}$ MELLO (2001, p. 121)

355 MELLO (2001, p. 117)

${ }^{356}$ GALINDO (2001, p. 130)

${ }^{357}$ GALINDO (2001, p. 175)
} 
diversas convenções internacionais, dentre as quais estão: o Pacto de Direitos Civis e Políticos, o Estatuto dos Refugiados, a Convenção da Eliminação de Todas as Formas de Discriminação contra a Mulher, a Convenção dos Direitos da Criança, a Convenção Americana sobre Direitos Humanos, a Convenção Européia de Direitos Humanos, a Convenção Européia para a prevenção da Tortura e Tratamento ou Punição Desumano ou Degradante e a Carta Social Européia. ${ }^{358}$

Em razão de sua especificidade, alguns doutrinadores consideram que as normas de tratados de direitos humanos teriam natureza de ius cogens, e, com isso, atingiriam a hierarquia de normas supraconstitucionais, independente do disposto na Constituição do país. ${ }^{359}$ Não se pode, contudo, com o intento de abarcar o maior número de direitos possíveis, elevar todos os direitos humanos à categoria de ius cogens, pois, com isso, eles se esvaziariam e acabariam por perder a proteção especial que deveriam ter. Como forma de balizamento, adotaremos o que foi proposto pela Corte Internacional de Justiça no Caso "Barcelona Traction", a ver: a proibição do genocídio e os direitos fundamentais da pessoa humana, sendo considerado como esse último exemplo apenas a proteção contra a escravidão e contra a discriminação racial, já que seu caráter seria demasiadamente impreciso. ${ }^{360}$

A noção de community interest abrange três ideias principais a serem defendidas por todos os Estados: a comunidade internacional seria formada por indivíduos, além de Estados; a possibilidade de interferência de demais Estados em relações bilaterais, fiscalizando a proteção dos direitos humanos e outras obrigações para com a comunidade internacional; e a institucionalização da comunidade internacional, visando a garantir os interesses da própria comunidade, como ente próprio - por meio de órgãos de fiscalização dos direitos humanos, tribunais internacionais e mesmo uma opinião pública internacional. ${ }^{361}$

Por un lado, la possibilidad de la cooperación encubre grandes oportunidades y desafios: los elementos constitutivos del Estado constitucional (como los procedimientos democráticos, la independencia de la jurisdicción, los derechos humanos) pueden ser "exportados", a fin de constituir a la comunidad de los Estado. ${ }^{362}$

Com isso, a despeito da crítica distintiva entre pluralismo e relativismo, devemos ter cuidado para não exportarmos, na verdade, um modelo de vida, sem respeitar, assim, a diversidade cultural - e por cultura nos referimos a todas as manifestações, inclusive

\footnotetext{
${ }^{358}$ GALINDO (2001, p. 255)

${ }^{359}$ GALINDO (2001, p. 227)

${ }^{360}$ GALINDO (2001, p. 248)

${ }^{361}$ GALINDO (2001, p. 150)

362 HÄBERLE (2003, p. 69)
} 
o Direito - pois somente após os horrores que o ocidente experienciou durante a Segunda Guerra Mundial é que países como a França passaram a adotar a primazia do Direito Internacional em suas Constituições. ${ }^{363}$

Em termos de pluralidade de convicções e distintos modos de vida, outra indagação de maior profundidade se coloca diante de nós, desafiando-nos a revelar qual o critério de verdade que legitimaria a imposição de crenças particulares à obediência geral, como acontece na seara dos direitos humanos, por exemplo, cujas solenes Declarações, embora autodenominadas universais, são vistas pelos críticos como textos ocidentais e, por isso mesmo, carentes de normatividade para quem vive do outro lado do mundo e ali se conduz em conformidade com valores diversos. ${ }^{364}$

Além disso, o atual estágio do Estado de Direito em que nos encontramos exige uma postura positiva do Estado - e, por isso, mais difícil de ser imposta por meio de normas internacionais -, no sentido de se conformar aos direitos de terceira geração, e também de assegurá-los. Assim, até mesmo o legislador possui o dever de concretizar os direitos previstos em âmbito internacional com observância ao núcleo essencial dos direitos em sua conformação por meio da ponderação. ${ }^{365}$

\subsection{AS CONSEQUÊNCIAS DA APLICAÇÃO DA TEORIA DA}

\section{SUPRALEGALIDADE NO BRASIL}

Conforme analisamos, a teoria da supralegalidade das normas internacionais, segundo o entendimento do Supremo Tribunal, só se aplica, no Brasil, aos casos de tratados que versem sobre a matéria de direitos humanos - matéria essa difícil de ser definida. $\mathrm{O}$ Estado Constitucional Cooperativo em que nos encontramos é, na verdade, a terceira fase evolutiva do Estado de Direito, como explana Pérez Luño, e isso exige uma posição positiva e mais preocupada do Estado no tocante aos direitos fundamentais - esses vão além dos direitos de seus cidadãos, pois envolvem direitos como o direito ao meio ambiente, por exemplo, que envolve toda a humanidade.

A las tres generaciones de Estados de derecho corresponden, por tanto, tres
generaciones de derechos fundamentales. El Estado liberal, que representa la
primera generación o fase del Estado de derecho, es el marco en el que se
afirman los derechos fundamentales de la primera generación, es decir, las
libertades de signo individual. El estado social, que encarna la segunda
generación del Estado de derecho, será el âmbito jurídico-político en el que

\footnotetext{
${ }^{363}$ MELLO (2001, p. 117-118)

${ }^{364}$ COELHO (2010)

${ }^{365}$ RE n. $466.343 / \mathrm{SP}$ (2006, p. 51 et seq.)
} 
se postulen los derechos econômicos, sociales y culturales. El Estado constitucional, en cuanto Estado de derecho de la tercera generación, delimitará el médio espacial y temporal de paulatino reconocimiento de los derechos de la tercera generación. ${ }^{366}$

Por outro lado, não devemos ser ingênuos em imaginar que o simples fato de possuir uma Constituição nos trará a efetividade desses direitos. Tanto o cumprimento da Constituição, quanto das normas internacionais, respeitando a vontade de cada um deles - e não uma vontade política - exige uma postura participativa dos detentores do direito. Afinal, como está expresso na Constituição de 1988, o povo é soberano, e não mais o governante.

O constitucionalismo, por si só, não é capaz de derrotar algumas das vicissitudes que têm adiado a plena democratização da sociedade brasileira. (O Direito tem seus limites e possibilidades, não sendo o único nem sequer o melhor instrumento de ação social.) Tais desvios envolvem, em primeiro lugar, a ideologia da desigualdade. Desigualdade econômica, que se materializa no abismo entre os que têm e os que não têm, com a conseqüente dificuldade de se estabelecer um projeto comum de sociedade. Desigualdade política, que faz com que importantes opções de políticas públicas atendam prioritariamente aos setores que detêm força eleitoral e parlamentar, mesmo quando já sejam os mais favorecidos. Desigualdade filosófica: o vício nacional de buscar o privilégio em vez do direito, aliado à incapacidade de perceber o outro, o próximo. ${ }^{367}$

Deve ser frisado também que, apesar do caráter legal, e não supralegal, das normas internacionais que tratem de matéria diversa da dos direitos humanos, o seu descumprimento importará em responsabilidade internacional, a despeito dos negadores do Direito Internacional alegarem que não há sanções nesse ramo do Direito.

Responsabilidade Internacional tem a ver principalmente com a efetividade do Direito Internacional. Qualquer sistema jurídico que prescinde de um sistema de responsabilidade é fadado ao insucesso. A relativização ou mesmo a tentativa de eliminar o problema da responsabilidade internacional, como fazem alguns juízes internos, pode gerar inúmeras consequiências danosas para o Estado. Uma cultura de descumprimento pode ir de encontro aos interesses do próprio Estado brasileiro, que muitas vezes pode ter interesse que determinado membro da comunidade internacional cumpra fielmente normas pactuadas internacionalmente. ${ }^{368}$

Assim, para evitar sanções diplomáticas, o Brasil deve, antes de ratificar um tratado, analisar, por meio de seu corpo técnico, todas as vertentes que aquele pacto traria ao país, sejam elas políticas, econômicas, jurídica ou até mesmo social, e verificar se essas consequências são convenientes e interessantes ao Estado. Dessa forma, por meio de um controle prévio exercido em diversas instâncias - pelo Legislativo antes da aprovação, pelo

\footnotetext{
${ }^{366}$ PÉREZ LUÑO (2002, p. 94-95)

${ }^{367}$ BARROSO (2008, p. 341)

${ }^{368}$ GALINDO (2001, p. 151)
} 
Executivo antes da ratificação e pelo Judiciário por meio de ações diretas que analisem a constitucionalidade do Decreto Legislativo após a aprovação do Parlamento e antes da ratificação pelo Presidente da República - o país somente pactuará aquilo que lhe for possível cumprir.

A busca pelo controle do tipo preventivo, e não reparador, é ideal a fim de evitar conflitos e contradições entre o Direito Internacional e o Direito Interno, sendo o que se pede, sob uma perspectiva internacionalista e mesmo de um constitucionalismo responsável e sensível às questões internacionais. O controle preventivo permite que o Estado não ratifique, renegocie ou ratifique com reservas o tratado. ${ }^{369}$

Os tratados que não sejam sobre direitos humanos não podem ser considerados como ilegais no momento de sua promulgação, pois, por possuírem estatura hierárquica equivalente à de lei, revogam qualquer lei que lhe seja contrária - princípio lex posterior derrogat legi priori. No entanto, em razão também da aplicação desse princípio, se o legislador ordinário editar uma norma que lhe seja contrária posteriormente, ele será revogado e tão logo descumprido em âmbito internacional, o que gerará a responsabilização do Estado perante os tribunais internacionais. Diante dessa problemática, entendemos que a proteção dada aos tratados de direitos humanos deve necessariamente ser estendida aos demais, para que o Brasil se torne um ente confiável perante a comunidade internacional.

${ }^{369}$ GALINDO (2001, p. 172) 


\section{CONCLUSÃO}

O presente trabalho buscou demonstrar a importância do Direito Internacional e de sua efetivação e aplicabilidade a partir de sua inserção nos ordenamentos jurídicos internos. A relevância do tema se encontra no aprofundamento das interações entre os sujeitos de Direito Internacional dentro de um contexto contemporâneo, em que o indivíduo, seja ele de que nação for, passou a ser visto não apenas como objeto ou mero destinatário, mas também como razão para a existência do Direito.

No entanto, vislumbramos que nem sempre os interesses dos agentes sociais são convergentes e, então, se inicia uma batalha por orgulho e poder - a título de soberania e independência - em que, a maior parte das vezes, o objetivo principal é esquecido. Os discursos adotados não correspondem à realidade ou, se correspondem, são meros pretextos para se atingir interesses egoísticos. O Direito surge, então, para tentar assegurar a efetiva cooperação entre os países, de modo que não se sobreponham os interesses daqueles que detêm maior poder econômico ou bélico, mas seja assegurada a isonomia real e os direitos fundamentais do ser humano.

Tentou-se demonstrar que, ao longo de sua história, o Brasil viveu momentos democráticos, de valorização dos princípios mais caros à humanidade, e outros, nem tanto. De qualquer maneira, caminhamos para o atual estágio de desenvolvimento das ideias haberlianas, que encontram, na jurisprudência do Supremo Tribunal Federal, o início da integração do Brasil aos outros países no que se refere à proteção do indivíduo.

Reconhecemos que, ao adotar a teoria da supralegalidade das normas internacionais de direitos humanos, o Supremo Tribunal Federal deu um grande avanço. Contudo, não se pode imaginar que a questão tenha sido solucionada da melhor forma ou de modo definitivo. Vale lembrar que, caso o constituinte derivado regulamente a prisão do depositário infiel por meio de uma Emenda Constitucional, a Convenção Americana de Direitos Humanos voltará a ser descumprida. Ainda que a doutrina mais garantista considere que a referida norma estaria inserida no ordenamento como cláusula pétrea e, em razão disso, não poderia ser abolida nem mesmo por meio de Emenda, acreditamos que o Supremo não seguiria essa linha de raciocínio, por se prender ao positivismo, sem buscar a teleologia das normas constitucionais.

Ademais, a Súmula Vinculante que foi editada trata especificamente da questão do depositário infiel, sem se referir à questão da hierarquia normativa dos tratados, ainda que 
de direitos humanos. Considerando, assim, que os julgamentos que analisamos teriam eficácia inter partes, por serem controle de constitucionalidade difuso, a teoria neles adotada somente seria estendida a todos, isto é, teria eficácia geral, caso o Senado exercesse sua competência privativa de suspender a norma contrária ao ordenamento, segundo o disposto no art. 52, X da Constituição - no caso, seria propor uma Emenda à Constituição que previsse a supralegalidade das normas internacionais. De igual maneira, os julgamentos teriam eficácia geral também se a Súmula Vinculante se referisse diretamente à supralegalidade dos tratados de direitos humanos quando em conflito com normas internas. Como nenhuma dessas fórmulas foi adotada, nada garante que o entendimento do Supremo permanecerá aliado à teoria da supralegalidade das normas internacionais, podendo ser alterado até mesmo em função de circunstâncias subjetivas, inclusive políticas.

Além disso, os tratados que versem sobre outras matérias que não a de direitos humanos continuam equiparados à lei hierarquicamente, o que faz com que se tornem frágeis, podendo considerados ilegais caso lei posterior adote conduta contrária à prevista no tratado. Seu cumprimento resta, assim, prejudicado, mesmo sem que o Brasil o denuncie. O descumprimento de normas internacionais leva ao desânimo e ao ceticismo em relação à diplomacia, restando, apenas, a esperança de mudança, em consonância com Rezek:

$\mathrm{O}$ dia virá em que, lembrando as coisas que aconteceram nestes primeiros anos do século XXI, todos, mas sobretudo os operadores do direito, teremos dificuldade em acreditar que tudo isto realmente aconteceu, que as palavras que ouvimos realmente foram ditas, que as cenas que acompanhamos à distância não eram encenação de uma ópera de horror. $\mathrm{O}$ dia virá em que, superado este fosso de sombras para o direito internacional e a sociedade das nações, hesitaremos em dar crédito à memória quando ela nos insinuar que isso não foi um delírio. Nossa esperança é que esse novo tempo não demore a chegar. ${ }^{370}$

Conclui-se, então, que nosso país deve seguir com o crescimento da proteção aos direitos humanos, ampliando-a sempre mais. Além disso, entendemos que essa proteção deve ser estendidas às outras espécies de normas internacionais, uma vez que o seu cumprimento se mostra essencial, não apenas para evitar a responsabilização no plano internacional, mas também para que o Brasil seja inserido definitivamente na comunidade internacional como um Estado que cumpre com seus compromissos - o que lhe daria até mesmo a possibilidade de obter a vaga no Conselho de Segurança das Organizações Unidas que tanto pleiteia.

${ }^{370}$ REZEK (2008b, p. 679) 


\section{REFERÊNCIAS BIBLIOGRÁFICAS}

ACCIOLY, Hildebrando. Manual de direito internacional público. 14. ed. São Paulo: Saraiva, 2000.

ALEXY, Robert. Direitos fundamentais no estado constitucional democrático. In: Revista de Direito Administrativo, Rio de Janeiro, v. 217, p. 58 et seq., jul./set. 1999.

AMARAL JÚNIOR, Alberto do. A proteção internacional dos direitos humanos. In: Revista de Informação Legislativa, Brasília, a. 39, n. 155, jul./set. 2002.

ANDRÉ, André Luiz Pedro. As ordenações e o direito privado brasileiro. Disponível em: <http://www.estig.ipbeja.pt/ ac_direito/AndreAndre.pdf>. Acesso em: 20 jun. 2011.

BARROSO, Luís Roberto. Interpretação e aplicação da Constituição: fundamentos de uma dogmática constitucional transformadora. 6. ed. São Paulo: Saraiva, 2008.

BOBBIO, Norberto. A era dos direitos. Rio de Janeiro: Editora Campus, 1992.

Teoria Geral da Política: a filosofia política e as lições dos clássicos. Rio de Janeiro: Elsevier, 2000.

BOSON, Gerson de Britto Mello. Constitucionalização do direito internacional:

internacionalização do direito constitucional: direito constitucional internacional brasileiro. Belo Horizonte: Del Rey, 1996.

BRASIL. Constituição (1988). Constituição da República Federativa do Brasil. Brasília: Senado Federal, 2010.

. Supremo Tribunal Federal. Ação Direta de Inconstitucionalidade. ADI n.

1.480/DF. Relator. Requerentes: CNT e CNI. Intimados: Congresso Nacional e Presidente da República. Relator: Min. Celso de Mello. Brasília, 27 de junho de 2001. Disponível em: < http://www.stf.jus.br/portal/processo/verProcessoAndamento.asp?incidente=1646696 $>$ Acesso em: 20 jun. 2011.

. Supremo Tribunal Federal. Habeas Corpus. HC n. 72.131/RJ. Tribunal Pleno.

Pacientes: Lairton Almagro Vitoriano da Cunha e Sateplan Consórcios LTDA. Impetrante: Marcello Ferreira de Souza Granado. Coator: TJRJ. Relator: Min. Marco Aurélio. Brasília, 23 de novembro de 1995. Disponível em: < http://www.stf.jus.br/portal/processo/verProcessoAndamento.asp?incidente=1603947> Acesso em: 20 jun. 2011.

. Supremo Tribunal Federal. Habeas Corpus. HC n. 87.585/TO. Tribunal Pleno. Paciente: Alberto de Ribamar Ramos Costa. Impetrante: Alberto de Ribamar Ramos Costa. Coator: STJ. Relator: Min. Marco Aurélio. Brasília, 3 de dezembro de 2008. Disponível em: < http://www.stf.jus.br/portal/processo/verProcessoAndamento.asp?incidente=2345410 $>$ Acesso em: 20 jun. 2011. 
Supremo Tribunal Federal. Recurso Extraordinário. RE n. 80.004/SP. $1^{\text {a }}$ Turma. Recorrente: João dos Santos Ronqui. Recorrido: Ministério Público Federal. Relator: Min. Octavio Gallotti. Brasília, 21 de março de 2000. Disponível em: < http://www.stf.jus.br/portal/processo/verProcessoAndamento.asp?incidente=1808056 > Acesso em: 20 jun. 2011.

Supremo Tribunal Federal. Recurso Extraordinário. RE n. 349.703/RS. Tribunal Pleno. Recorrente: Banco Itaú S/A. Recorrido: Armando Luiz Segabinazzi. Relator: Min. Ayres Britto. Brasília, 3 de dezembro de 2008. Disponível em: < http://www.stf.jus.br/portal/processo/verProcessoAndamento.asp?incidente=2035659 > Acesso em: 20 jun. 2011.

. Supremo Tribunal Federal. Recurso Extraordinário. RE n. 466.343/SP. Tribunal Pleno. Recorrente: Banco Bradesco S/A. Recorrido: Luciano Cardoso Santos. Relator: Min. Cezar Peluso. Brasília, 3 de dezembro de 2008. Disponível em: < http://www.stf.jus.br/portal/processo/verProcessoAndamento.asp?incidente=2343529 > Acesso em: 20 jun. 2011.

BRUNNÉE, Jutta; TOOPE, Stephen J. The Use of Force: International Law After Iraq. In: The International and Comparative Law Quarterly. Cambridge, vol. 53, nº 4, p. 785-806, 2004.

BRUNO NETO, Francisco. Direito Constitucional Internacional. Disponível em: < http://www.profbruno.com.br/03\%20DIREITO\%20CONSTITUCIONAL/RES\%2021a\%20A ULA\%20-\%20DIREITO\%20CONSTITUCIONAL\%20INTERNACIONAL.pdf > . Acesso em: 20 jun. 2011.

CANOTILHO, José Joaquim Gomes. Direito Constitucional. 2. ed. Coimbra, Portugal: Livraria Almedina, 1998.

CHETAIL, Vincent. The contribution of the International Court of Justice to international humanitarian law. In: International Review of the Red Cross. Geneva, vol. 85, n. 850, 235269, jun. 2003.

COELHO, Inocêncio Mártires. Ativismo judicial: o caso brasileiro. Disponível em: $\langle$ http://www.osconstitucionalistas.com.br/ativismo-judicial-o-caso-brasileiro $>$. Acesso em: 20 jun. 2011.

CORTE INTERAMERICANA DE DIREITOS HUMANOS. Sentença. Gomes Lund e Outros (Guerrilha do Araguaia) vs. Brasil. 24 de novembro de 2010. Disponível em: <http://www.corteidh.or.cr/casos.cfm?idCaso=348>. Acesso em: 12 jan 2011.

CORTE INTERNACIONAL DE JUSTIÇA. Estatuto. São Francisco, 1945. Disponível em: $<$ http://www.direitoshumanos.usp.br/index.php/Corte-Internacional-deJusti\%C3\%A7a/estatuto-da-corte-internacional-de-justica.html>. Acesso em: 20 jun. 2011.

GALINDO, George Rodrigo Bandeira. Conflito entre tratados internacionais de direitos humanos e constituição: uma análise do caso brasileiro. 2001. Dissertação (Mestrado). Faculdade de Direito, Universidade de Brasília. Brasília, 2001. 
HÄBERLE, Peter. El Estado Constitucional. Cidade do México: Universidad Nacional Autónoma de México, 2003.

JACKSON, Robert; SORENSEN, Georg. Introdução às Relações Internacionais. 1. ed. Rio de Janeiro: Jorge Zahar, 2007.

JANKOV, Fernanda Florentino Fernandez. Direito Internacional Penal: mecanismos de implementação do Tribunal Penal Internacional.São Paulo: Saraiva, 2009.

KOSHIBA, Luiz; PEREIRA, Denise Manzi Frayze. História do Brasil: no contexto da história ocidental. 8. ed. São Paulo: Atual, 2003.

LAMARÃO, Patrícia. Comentários a Peter Häberle. Disponível em: < http://www.osconstitucionalistas.com.br/comentarios-a-peter-haberle> Acesso em: 20 jun. 2011.

LIMA, Raquel Negreiros Silva. A constitucionalidade dos tratados de direitos humanos: uma reflexão sobre a possibilidade de adoção desse novo entendimento pelo Supremo Tribunal Federal. 2010. Monografia (Graduação). Faculdade de Direito, Universidade de Brasília. Brasília, 2010.

LOHN, Fernanda. O Supremo Tribunal Federal é uma Corte Constitucional? Disponível em: <http://www.osconstitucionalistas.com.br/o-supremo-tribunal-federal-e-uma-corteconstitucional> Acesso em: 20 jun. 2011.

LUHMANN, Niklas. A posição dos tribunais no sistema jurídico. Revista da AJURIS. Porto Alegre, ano XVII, n. 49, p. 149-168, jul. 1990.

LUQUINI, Roberto de Almeida. A aplicação do Direito Internacional Humanitário nos "conflitos novos": Conflitos desestruturados e conflitos "de identidade" ou étnicos. In: Revista de Informação Legislativa. Brasília, a. 40, n. 158, abr./jun. 2003.

MELLO, Celso Duvivier de Albuquerque. Curso de direito internacional público. 13. ed. Rio de Janeiro: Renovar, 2001.

MENDES, Gilmar Ferreira; COELHO, Inocêncio Mártires; BRANCO, Paulo Gustavo Gonet. Curso de Direito Constitucional. São Paulo: Saraiva, 2007.

MONTESQUIEU. Do Espírito das leis. São Paulo: Martin Claret, 2007.

MORRIS, Clarence. Os grandes filósofos do direito: leituras escolhidas em direito. São Paulo: Martins Fontes, 2002.

NEVES, Marcelo. Transconstitucionalismo. São Paulo: Martins Fontes, 2009.

PELUSO, Cezar. Consolidação da democracia e a reforma do Judiciário no Brasil.

Disponível em: <http://www.osconstitucionalistas.com.br/consolidacao-da-democracia-ereforma-do-judiciario-no-brasil>. Acesso em: 20 jun. 2011. 
PEREIRA, Marcos Vinícius Torres. Homologação de sentenças penais estrangeiras no direito internacional privado brasileiro. Disponível em: <http://www.epublicacoes.uerj.br/index.php/rfduerj/article/viewFile/1354/1142>. Acesso em: 20 jun. 2011.

PÉREZ LUÑO, Antonio-Enrique. La universalidad de los derechos humanos y el Estado constitucional. Bogotá: Universidad Externado de Colombia, 2002.

RAMOS, André de Carvalho. O impacto da Convenção Americana de Direitos Humanos na relação do Direito Internacional e o Direito Interno. In: Boletim Científico da Escola

Superior do Ministério Público da União, Brasília, a. I, n. 4, jul./set. 2002.

REZEK, José Francisco. Direito internacional público: curso elementar. 11. ed. São Paulo: Saraiva, 2008a.

. "Nova Ordem" e crise do Direito Internacional. In: ROCHA, Maria Elisabeth Guimarães Teixeira; PETERSEN, Zilah Maria Callado Fadul (coord.) Coletânea de Estudos Jurídicos - Bicentenário da Justiça Militar no Brasil. Brasília: Supremo Tribunal Militar, 2008b.

SANTOS, Davi Hoerlle. CIDH vs. STF: O caso $n^{\circ} 11.552$ (Guerrilha do Araguaia) em confronto com a ADPF no. 153 (Lei de Anistia). 2011. Monografia (Graduação). Centro Universitario de Brasília - UniCEUB. Brasília, 2011.

SOUZA, Ielbo Marcus Lobo de. A natureza e eficácia do direito internacional. In: Revista de Informação Legislativa, Brasília, a. 36, n. 141, jan./mar. 1999.

STEIGER, Heinhard. From the International Law of Christianity to the International Law of the World Citizen: reflections on the Formation of the Epochs of the History of International Law. In: Journal of the History of International Law. n. 3. p. 180-93. Holanda: Martinus Nijhoff, 2001.

SUNDFELD, Carlos Ari. Fundamentos de direito público. 4. ed. São Paulo: Malheiros, 2006.

TRINDADE, Antônio Augusto Cançado. A nova dimensão do Direito Internacional Público. Brasília: Instituto Rio Branco, 2003.

VALE, André Rufino do; MENDES, Gilmar Ferreira. A influência do pensamento de Peter Häberle no STF. In: Revista Consultor Jurídico, 2009. Disponível em: <http://www.conjur.com.br/2009-abr-10/pensamento-peter-haberle-jurisprudencia-supremotribunal-federal >. Acesso em: 20 jun. 2011.

VENTURA, Carla A. Arena. Da Negociação à Formação dos Contratos Internacionais do Comércio: Especificidades do Contrato de Compra e Venda Internacional. In: Revista Eletrônica de Direito Internacional, vol. 6, 2010. Disponível em: < http://www.cedin.com.br/revistaeletronica/volume6/> Acesso em 20 jun. 2011. 